WT-1467

AEC Category: HEALTH AND SAFETY Military Category: 42
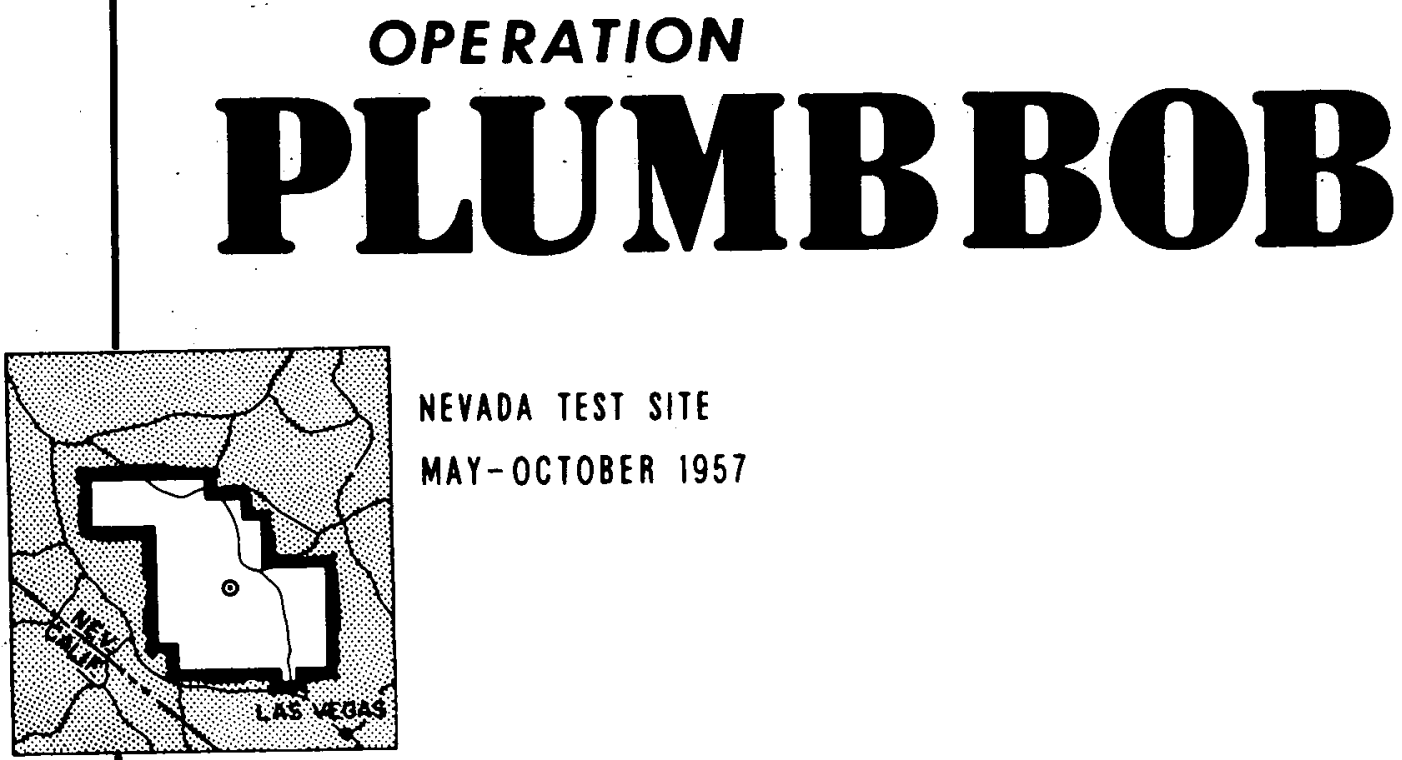

NEVADA TEST SITE

MAY-OCTOBER 1957

Project 33.1

BLAST BIOLOGY - A STUDY OF THE PRIMARY AND TERTIARY EFFECTS OF BLAST IN OPEN UNDERGROUND PROTECTIVE SHELTERS

Issuance Date: June 30, 1959 


\section{DISCLAIMER}

This report was prepared as an account of work sponsored by an agency of the United States Government. Neither the United States Government nor any agency Thereof, nor any of their employees, makes any warranty, express or implied, or assumes any legal liability or responsibility for the accuracy, completeness, or usefulness of any information, apparatus, product, or process disclosed, or represents that its use would not infringe privately owned rights. Reference herein to any specific commercial product, process, or service by trade name, trademark, manufacturer, or otherwise does not necessarily constitute or imply its endorsement, recommendation, or favoring by the United States Government or any agency thereof. The views and opinions of authors expressed herein do not necessarily state or reflect those of the United States Government or any agency thereof. 


\section{DISCLAIMER}

Portions of this document may be illegible in electronic image products. Images are produced from the best available original document. 


\section{NOTICE}

This report is published in the interest of providing information which may prove of value to the reader in his study of effects data derived principally from nuclear weapons tests.

This document is based on information available at the time of preparation which may have subsequently been expanded and re-evaluated. Also, in preparing this report for publication, some classified material may have been removed. Users are cautioned to avold Interpretations and conclusions based on unknown or incomplete data.

PRINTED IN USA

Price $\$ 1.75$. Available from the Office of Technical Services, Department of Commerce, Washington 25, D. C. 
Report to the Test Director

\title{
BLAST BIOLOGY-A STUDY OF THE PRIMARY AND TERTIARY EFFECTS OF BLAST IN OPEN UNDERGROUND PROTECTIVE SHELTERS
}

\author{
By \\ D. R. Richmond, R. V. Taborelli, I. G. Bowen, T. L. \\ Chiffelle, F. G. Hirsch, B. B. Longwell, J. G. Riley, \\ C. S. White, F. Sherping, V. C. Goldizen, J. D. Ward, \\ M. B. Wetherbe, V. R. Clare, M. L. Kuhn, and \\ R. T. Sanchez
}

\author{
Approved by: CLAYTON S. WHITE \\ Director \\ Program 33
}

\author{
Approved by: R. L. CORSBIE \\ Director \\ Civil Effects Test Group
}

Lovelace Foundation for Medical Education and Research Albuquerque, New Mexico

February 1959 
. 


\section{ABSTRACT}

Dogs, pigs, rabbits, guinea pigs, and mice were exposed to nuclear detonations in two open underground partitioned shelters. The shelters were of similar construction, and each was exposed to separate detonations. Each inner chamber filled through its own "orifice"; thus four separate pressure environments were obtained. An aerodynamic mound was placed over the escape hatch of each structure to determine its effect on the pressure-curve shape inside the chamber. In one test a sieve plate bolted across the top of the mound was evaluated. Wind protective baffles of solid plate and of heavy wire screen were installed in the shelters to compare primary and tertiary blast effects on dogs. The shelters also contained static and dynamic pressure gauges, radiation detector 8 , telemetering devices, and, in one test, air-temperature measuring instruments, dust-collecting trays, and eight pigs for the biological assessment of thermal effects.

One dog was severely injured from tertiary blast effects associated with a maximal dynamic pressure $(Q)$ of $10.5 \mathrm{psi}$, and one was undamaged with a maximal $Q$ of $2 \mathrm{psi}$. Primary blast effects resulting from peak overpressures of $30.3,25.5,9.5$, and 4.1 psi were minimal. The mortality was 19 per cent of the mice exposed to a peak pressure of 30.3 psi and 5 and 3 per cent of the guinea pigs and mice exposed to a peak pressure of 25.5 psi. Many of the rabbits, guinea pigs, and mice sustained slight lung hemorrhages at maximum pressures of $\mathbf{2 5 . 5}$ and $30.3 \mathrm{psi}$. Eardrum perforation data for all species, except mice, were recorded.

Following shot 2, thermal effects were noted. Animals of the groups saved for observation have died from ionizing-radiation effects. 


\section{ACKNOWLEDGMENTS}

The authors are indebted to the following individuals for advice and cooperation and active participation in the planning and execution of this project:

R. L. Corsbie, Director, Civil Effects Test Group

L. J. Vortman, Sandia Corporation

Edward Bryant, Ballistic Research Laboratories

Dr. H. E. Pearse, Strong Memorial Hospital, Rochester, N. Y.

Division of Biology and Medicine, Atomic Energy Commission (Civil Effects Test Group)

for financial support with some assistance by the Federal Civil Defense Administration

Appreciation is expressed to R. A. Smith, G. S. Bevil, and R. A. MacMahon, Lovelace Foundation, for photographic work in the field; to $R$. A. Smith and A. W. Dennis for assistance in the preparation of illustrative material; to John D. McCurdy, A. W. Dennis, and E. R.

Fletcher for general support; to R. B. Thurman for the procurement and training of animals; and to Mrs. Isabell D. Benton and Mrs. Roberta H. Schlies for editorial and secretarial aid. 


\section{CONTENTS}

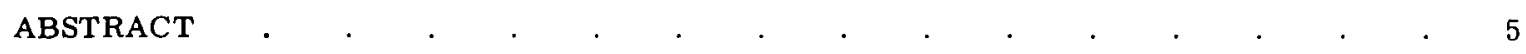

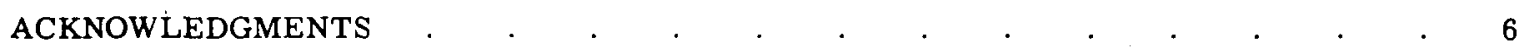

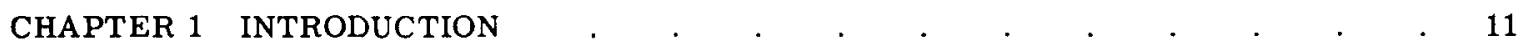

CHAPTER 2 PROCEDURE $\quad . \quad$.

2.1 Structural Shelters . . . . . . . . . . . . . . . 13

2.1 .1 General Description . . . . . . . . . . . . . 13

2.1.2 Aerodynamic Mound . . . . . . . . . . . . 13

2.2 Instrumentation. $. \quad . \quad . \quad . \quad . \quad . \quad . \quad . \quad . \quad . \quad . \quad . \quad 13$

2.2.1 Pressure-Time Gauge . . . . . . . . . . . . . . . . 13

2.2.2 Dynamic Pressure-Time Gauge . . . . . . . . . . . . 16

2.2.3 Air-Temperature Measurements . . . . . . . . . . . 16

2.2.4 Radiation Dosimetry _. . . . . . . . . . . . . . . 16

2.2.5 Dust Collectors . . . . . . . . . . . . . . . . . 19

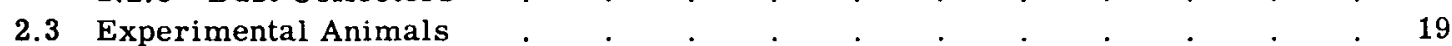

2.3.1 Animal Placements for Primary Blast Effects . . . . . . 19

2.3.2 Animal Placement for Tertiary Blast Effects . . . . . . $\quad 20$

2.4 General Remarks . . . . . . . . . . . . . . 24

2.4.1 Training of Animals . . . . . . . . . . . . . . . $\quad$. 24

2.4.2 Pathological Examination. . . . . . . . . . . . . . 24

CHAPTER 3 RESULTS $. \quad . \quad$.

3.1 General Observations _ . . . . . . . . . . . . . . . . $\quad . \quad 26$

3.1 Shot 1 . . . . . . . . . . . . . . . . 26

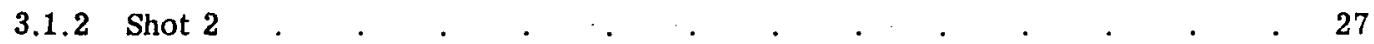

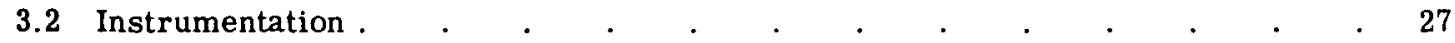

3.2.1 Pressure-Time Records _. . . . . . . . . . . . 27

3.2.2 Dynamic Pressure-Time Measurements . . . . . . . . 27

3.2.3 Air-temperature Measurements . . . . . . . . . . 27

3.2.4 Dust Collectors . . . . . . . . . . . . . . . 27

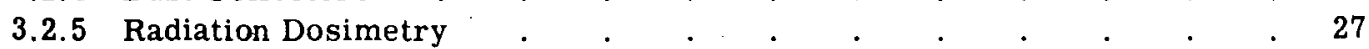

3.3 Pathology . . . . . . . . . . . . . . . . . . 29

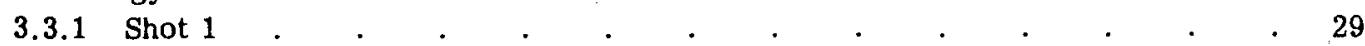

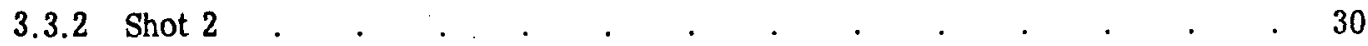

3.4 Pathological Effects as Related to the Pressure-Time Environment . . . 40

3.4.1 Mortality . . . . . . . . . . . . 40

3.4.2 Pulmonary Hemorrhage . $\quad$. $\quad$. $\quad$. $\quad$. $\quad$. . . . . . . . 43

3.4.3 Tympanic Membrane Rupture . . . . . . . . . . . . 45

3.4.4 Tertiary Blast Effects . . . . . . . . . . . . . . . . . 46 


\section{CONTENTS (Continued)}

3.5 Protective Baffles . . . . . . . . . . . . . . . . 46

3.6 Evaluation of the Aerodynamic Mound . . . . . . . . . . . $\quad$. 47

3.6.1 General . . . . . . . . . . . . . 47

3.6.2 Comparison of the Incident With the Internal Pressure-Time With
and Without the Aerodynamic Mound . . . . . 49

3.6.3 Measured vs. Predicted Pressure-Time in Chamber . . . . $\quad . \quad 52$

3.6.4 Comparison of the Wave Form in Chambers for Incident Waves
of the Ideal and Nonideal Types

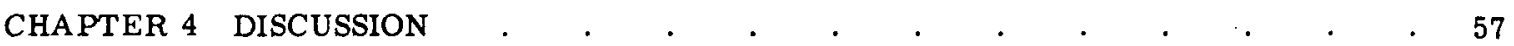

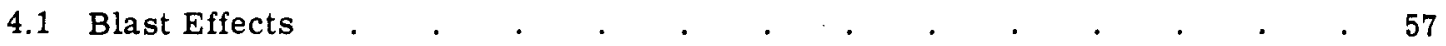

4.1 .1 General . . . . . . . . . . . . . . . 57

4.1 .2 Primary Blast . . . . . . . . . . . . . . 57

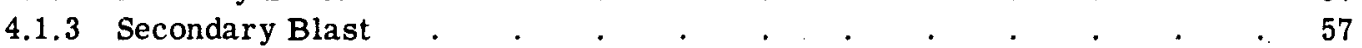

4.1.4 Tertiary Blast . . . . . . . . . . . . 57

4.2 Environmental Effects Other Than Blast . . . . . . . . . . $\quad . \quad 58$

4.2.1 Thermal Radiation . . . . . . . . . . . . . . 58

4.2.2 Ionizing Radiation . . . . . . . . . . . . . . . . 58

4.2.3 Dust . . . . . . . . . . . . . . . 58

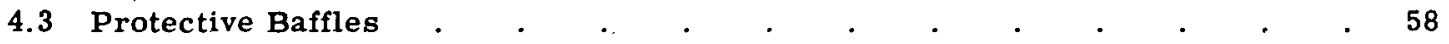

4.4 Aerodynamic Mound . $\quad . \quad$. $\quad . \quad$. $\quad . \quad$. $\quad . \quad . \quad . \quad . \quad .58$

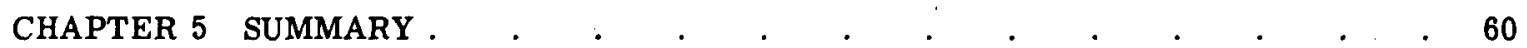

APPENDIX A TABULATION OF PATHOLOGICAL FINDINGS FOR SHELTER 8001 .

APPENDIX B TABULATION OF PATHOLOGICAL FINDINGS FOR SHELTER 8002 .

\section{ILLUSTRATIONS}

\section{CHAPTER 2 PROCEDURE}

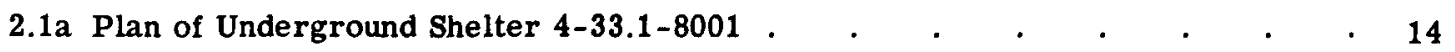

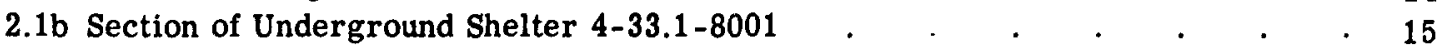

2.2 Aerodynamic Mound with Sieve-plate Cover (8002) • . . . . . . . 16

2.3 Location of Animals and Instruments in Shelter $8001 \quad$. . . . . . . 17

2.4 Location of Animals and Instruments in Shelter $8002 \quad$. . . . . . . . . 18

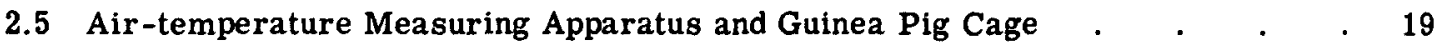

2.6 Solid Baffle and Shelf on Wall 1 of Shelter 8001 and Dynamic Pressure

2.7 Screen Baffle and Shelf on Wall 1 of Shelter 8002 and Dynamic Pressure Gauge . . . . . . . . . 21

2.8 Solid Baffle and Shelf on Wall 4 of Shelter 8001 . $\quad . \quad$. . . . . . $\quad{ }_{22}$

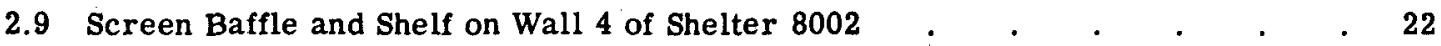

\section{CHAPTER 3 RESULTS}

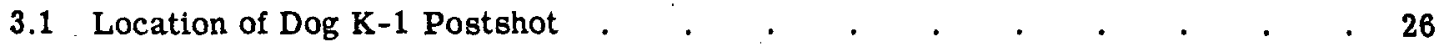

3.2a Damage to Aerodynamic Mound Above Shelter 8001 . $\quad$. $\quad$. $\quad$. $\quad$. $\quad$. 28

3.2b Damage to Aerodynamic Mound Above Shelter 8002 . $\quad$. . . . . . . $\quad 28$

3.3 Location of Dog G-1 Postshot, View from Entryway . . . . . . . . $\quad 29$

3.4 Pressure-Time Curves as Recorded Inside Shelter 8001 . . . . . . 31

3.5 Pressure-Time Curves as Recorded Inside Shelter 8002 . _ . . . . . . 32 


\section{ILLUSTRATIONS (Continued)}

3.6 Locations and Types of Measurements Recorded by the Various Radiation Dosimeters Within Shelter 8001 .

3.7 Locations and Types of Measurements Recorded by the Various Radiation Dosimeters Within Shelter 8002 .

3.8 Wall 2 of Shelter 8001 To Show Point of Impact for Dog K-1 . . . . . $\quad 35$

3.9a Fractured Lumbar Vertebra of Dog $\mathrm{K}-1$. . . . . . . . . . 37

$3.9 \mathrm{~b}$ Hemorrhaged Lining of Urinary Bladder from Dog K-1 . . . . . . $\quad . \quad 37$

3.10 Dorsal and Ventral Views of Lungs from Swine 5 and 7 . $\quad . \quad$. $\quad . \quad . \quad 39$

3.11 Mortality Curves for Mice Following Exposure to Radiation Within Shelter 8002

3.12 Mortality Curve for Guinea Pigs Following Exposure to Radiation Within Shelter 8002

3.13 Regression Lines Relating Percentage Mortality (Probit Unit) With the Log of the Pressure in the Reflected Shock

3.14 Mortality Curves for Guinea Pigs Exposed Against, and 12 In. from, the Closed End of a Shock Tube

3.15 Guinea Pig Eardrum Rupture as Related to Peak Pressure

3.16 Rabbit Eardrum Rupture as Related to Peak Pressure

3.18 Graph Comparing the Pressure-Time Recorded Outside, Within, and That Predicted for Inside the Slow-fill Chamber of Shelter 8001 (Plumbbob)

3.19 Graph Comparing the Pressure-Time Recorded Outside, Within, and That Predicted for Inside the Slow-fill Chamber of Shelter 8002 (Plumbbob)

3.20 Graph Comparing the Pressure-Time Recorded Outside, Within, and That Predicted for Inside the Slow-fill Chamber of Shelter 8001 (Teapot).

3.21 Graph Comparing the Pressure-Time Recorded Outside, Within, and That Predicted for Inside the Slow-fill Chamber of Shelter 8002 (Teapot) . . . 51

3.22 A Plot cf Values of $\mathrm{K}$ for Pressure Difference Across an Inlet . . . . $\quad$. 53

3.23 Comparison of the Pressure-Time Recorded Outside and Within the Fast-fill Chamber of Shelter 8001

3.24 Comparison of the Pressure-Time Recorded Outside and Within the Fast-fill Chamber of Shelter 8002

\section{TABLES}

\section{CHAPTER 2 PROCEDURE}

2.1 Numbers and Weights of the Various Animal Species Used in Both Shots . $\quad 20$

2.2 Number System and Location of Animals Placed in Shelter 8001, Shot 1 . $\quad 23$

2.3 Number System and Location of Animals Placed in Shelter 8002, Shot 2 . $\quad 24$

\section{CHAPTER 3 RESULTS}

3.1 Parameters of the Blast Wave Inside Shelters 8001 and 8002 . $\quad$. $\quad . \quad . \quad 32$

3.2 Summary of Pathological Findings for Animals Exposed in Shelter 8001 . . $\quad 36$

3.3 Summary of Pathological Findings for Animals Exposed in Shelter 8002 . . 40

3.4 Gross Pathological Findings in Guinea Pigs Exposed to Radiation Inside Shelter 8002

3.5 Criteria for Lung Blast Injury According to Lung Weight: Guinea Pig . $\quad 44$

3.6 Comparison of the Lung Weights for Blasted Animals to Those of Their

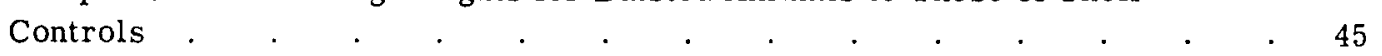

3.7 Tabulation of Tympanic Membrane Rupture as Related to Peak Pressure Inside Shelters .

3.8 Guinea Pig and Rabbit Eardrum Rupture as Related to Peak Overpressure Inside Shelters 


\section{TABLES (Continued)}

3.9 Dog Eardrum Rupture as Related to Peak Overpressure Inside Shelters . - 47

3.10 Pressure-Time Parameters Within the Slow-fill Chamber With and Without the Aerodynamic Mound

3.11 Comparison of the Measured with the Predicted Pressure-Time: Slow-fill Chambers

3.12 Pressure-Time Parameters Inside Chambers Subjected to Ideal and

Nonideal Incident Blast Waves

\section{APPENDIX A}

A.1 Tabulation of Pathological Findings for Shelter 8001: Dogs, Rabbits, and Guinea Pigs

A.2 Tabulation of Pathological Findings for Shelter 8001: Mice $\quad$. $\quad$. $\quad$. $\quad 65$

\section{APPENDIX B}

B.1 Tabulation of Pathological Findings for Shelter 8002: Dogs, Swine, Rabbits, and Guinea Pigs

B.2 Tabulation of Pathological Findings for Shelter 8002: Mice 


\section{Chapter 1}

\section{INTRODUCTION}

In reviews of the literature on biological effects of high-explosive blast, two conclusions are commonly found: namely, small-animal species are less resistant to blast than are larger species, and biological damage is intimately related to the magnitude and duration of the shock wave.$^{1-3}$ For example, a single sharp-rising high-explosive-produced blast wave of $11.8 \mathrm{msec}$ duration need only be near 76 psi for mortality to occur in dogs; whereas one of $1.6 \mathrm{msec}$ duration has to be 216 psi for mortality to occur. ${ }^{2}$

With the advent of nuclear blast, which produces pressure waves of several hundred to several thousand milliseconds duration, it became imperative to determine whether or not overpressures of relatively low magnitude but of long duration would be hazardous biologically.

Exposure of animals to nuclear blast in an open underground shelter during Operation Upshot-Knothole (included in reference 4) in 1953 suggested this may be the case. Dogs exhibited significant pulmonary hemorrhage at maximum pressures of only 12 to 25 psi of 430 to 570 msec duration. Also there was some evidence that the rate of pressure rise as well as the occurrence of a stepwise rise in pressure were parameters of biological significance. Later studies have established the significance of these factors. ${ }^{5,6}$

Experience during Operation Teapot in 1955 in which several animal species were exposed to a wide range of peak overpressures (1.4 to $85.8 \mathrm{psi}$ ) in a number of "open" blast protective shelters pointed out that long-duration overpressures per se were not particularly damaging, rather the translational effects due to the associative blast winds were more important even for animals restrained to minimize displacement. Subsequent laboratory work with long-duration overpressure has substantiated and extended the field studies completed in both 1953 and 1955 and, in addition, has pointed out that high pressures (well over 100 psi) of long duration can be tolerated by animals, provided the pressure is not applied too rapidly. ${ }^{5}$ To the contrary, however, lower peak pressures ( 25 to $50 \mathrm{psi}$ ) are known to be critical, if not fatal, to animals when a long-duration pulse incorporates a shock front and the associated, almost instantaneous, pressure rise. ${ }^{6}$

For a critical review of the blast literature, the reader is referred to the Operation Teapot report. ${ }^{4}$

It was the purpose of this project to expose animals to nuclear detonations in open underground shelters with the objective of further assessing not only the primary and tertiary biological blast effects but the total environment within the shelter; that is, thermal radiation, ionizing radiation, and dust. Large animals were tethered in a manner that would allow assessment of the effects of overpressure with and without associated blast winds by utilizing wind protective baffles.

Aerodynamic mounds, one with and one without a covering sieve plate, were tested above the escape hatches in an attempt to determine if the maximum pressure and rate of pressure rise inside the shelter would be attenuated. 


\section{REFERENCES}

1. S. Zuckerman, Experimental Study of Blast Injuries to the Lungs, Lancet, 2: 219-238 (Aug. 24, 1940).

2. Hans Desaga, Blast Injuries, in "German Aviation Medicine, World War II," Vol. II, Chap. XIV-D, pp.1274-1293, U. S. Government Printing Office, Washington, 1950.

3. Hjördis Celander, Carl-Johan Clemedson, Ulf A. Ericsson, and Holter I:son Hultman, A Study of the Relation Between the Duration of a Shock Wave and the Severity of the Blast Injury Produced by It, Acta Physiol. Scand., 33: 14-18 (1955).

4. C. S. White, T. L. Chiffelle, D. R. Richmond, W. H. Lockyear, I. G. Bowen, V. C. Goldizen, H. W. Merideth, D. E. Kilgore, B. B. Longwell, J. T. Parker, F. Sherping, and M. E. Cribb, The Biological Effects of Pressure Phenomena Occurring Inside Protective Shelters Following Nuclear Detonation, Operation Teapot Report, WT-1179, October 1956.

5. D. R. Richmond, M. B. Wetherbe, R. V. Taborelli, T. L. Chiffelle, and C. S. White, The Biological Response to Overpressure: I. Effects on Dogs of Five to Ten-Second Duration Overpressures Having Various Times of Pressure Rise, J. Aviation Med., 28: 447-460 (1957).

6. D. R. Richmond, The Biological Response to Sharp-Rising Pressures of Long Duration, AEC research report, in preparation. 


\section{Chapter 2}

\section{PROCEDURE}

\subsection{STRUCTURAL SHELTERS}

\subsubsection{General Description}

The two shelters involved in these experiments were utilized previously for biomedical studies during Operation Teapot ${ }^{1}$ in 1955 . They were of similar construction with the same orientation, and each was located at the same distance from Ground Zero, but were located in two separate firing areas ( 1 and 4 ). Consequently each was subjected to a different detonation. The structure involved in what will be called "shot 1 " was designated 8001 , and that involved in "shot 2," 8002. During. Operation Teapot they were designated 4-34.3b-1 and 1-34.3b-2, respectively. ${ }^{1}$

The shelters, located $5 \mathrm{ft}$ below the surface, were entered by an L-shaped flight of stairs (Figs. 2.1a and 2.1b). Inside there were two rooms, each $12 \times 12 \times 8 \mathrm{ft}$, separated by a reinforced-concrete partition in which was mounted a heavy steel bulkhead type door. The outer room with stairwell access was termed a "fast-fill" chamber since, by virtue of its position and opening to the surface, it would be subjected to the most rapid pressure change following the detonation.

The inner room, entered through the partition door, was termed the "slow-fill" chamber because the blast wave entered through an orifice plate placed over the open escape hatch. The partition doors were tightly sealed during each test.

\subsubsection{Aerodynamic Mound}

(a) Shot 1. In shot 1 an aerodynamic mound constructed above the 3-ft-square escape hatch leading into the slow-fill chamber of structure 8001 was evaluated. The inner diameter of the mound or effective metering orifice was $36 \mathrm{in}$. The latter consisted of a corrugated metal pipe $3 \mathrm{ft}$ in diameter welded to a 1 -in.-thick steel plate in which a 36 -in. orifice had been cut. See Figs. 2.1a and 2.1b.

(b) Shot 2. In shot 2 a similar aerodynamic mound was constructed over the escape hatch; in addition, a $1 / 2$-in.-thick sieve plate was bolted over its top. This plate was a composite of four $1 / 8$-in. -thick plates perforated with matching $1 / 4$-in. -diameter holes staggered on $1 / 2$-in. centers. The sieve plate contained 23 per cent open area or $1.63 \mathrm{sq} \mathrm{ft} \mathrm{(Fig.} \mathrm{2.2).}$

\subsection{INSTRUMENTATION}

\subsubsection{Pressure-Time Gauge}

Six Ballistic Research Laboratories (BRL) self-recording mechanical pressure-time gauges were flush mounted in the inner walls of each structure by personnel of CETG Project 39.2

(ITR-1501). Each of the walls in the fast-fill chamber contained a gauge, and there were two in 


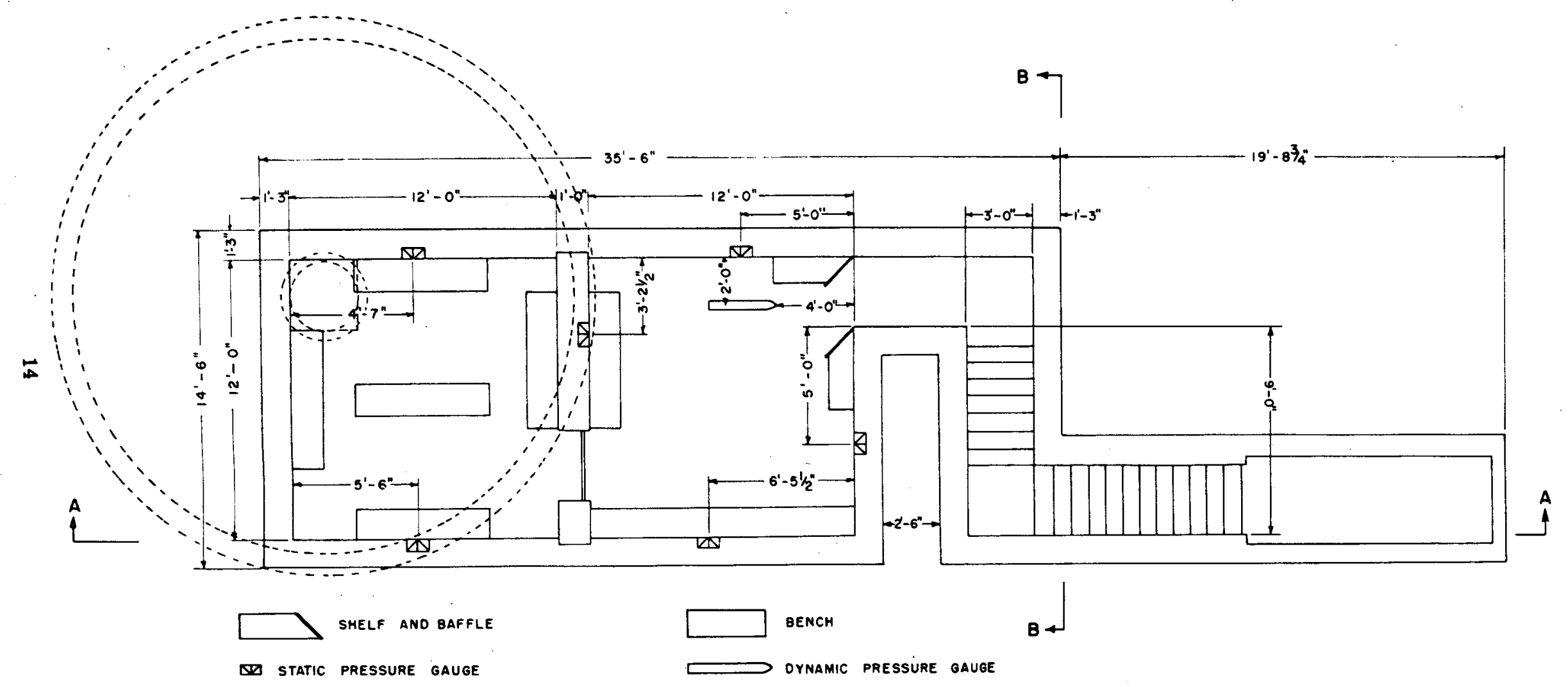

Fig. 2.1a-Plan of underground shelter 4-33.1-8001. 


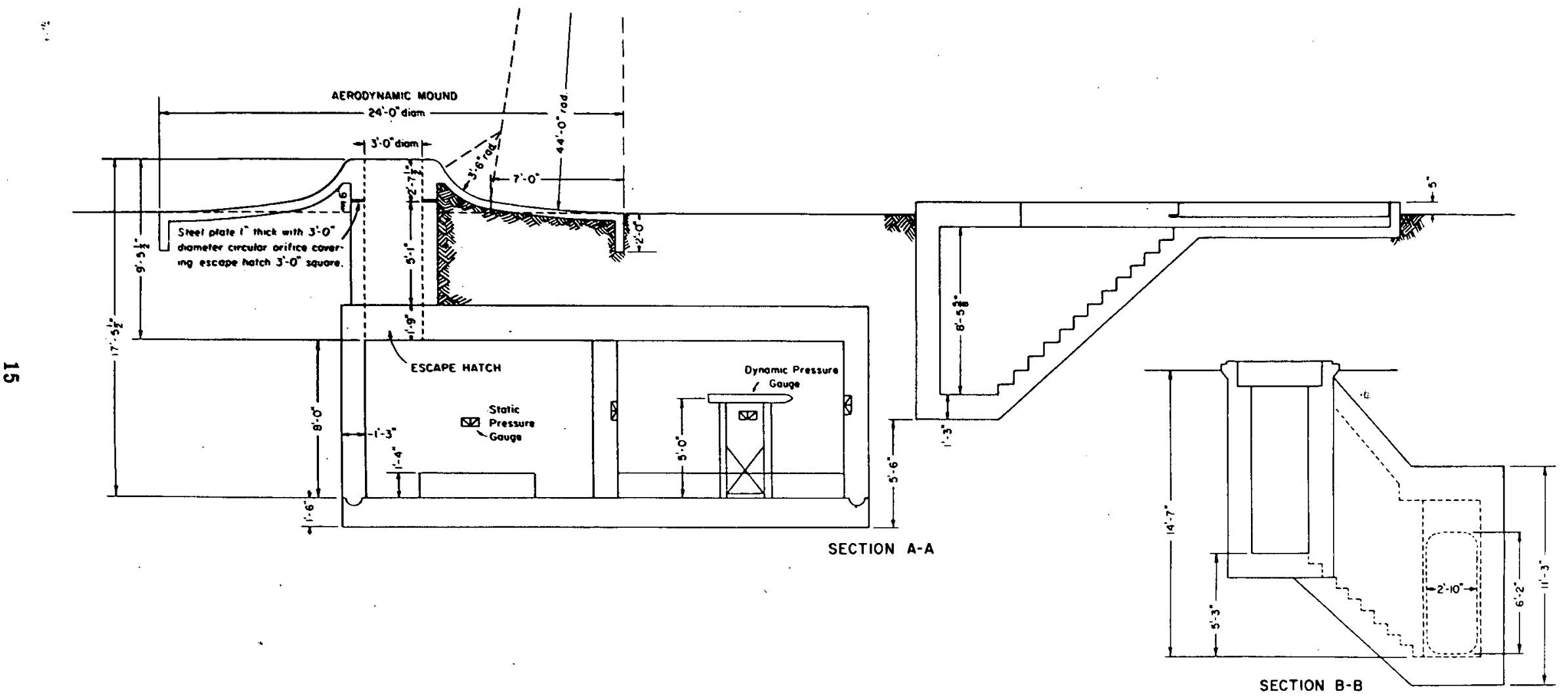

Fig. 2.1b-Section of underground shelter 4-33.1-8001. 


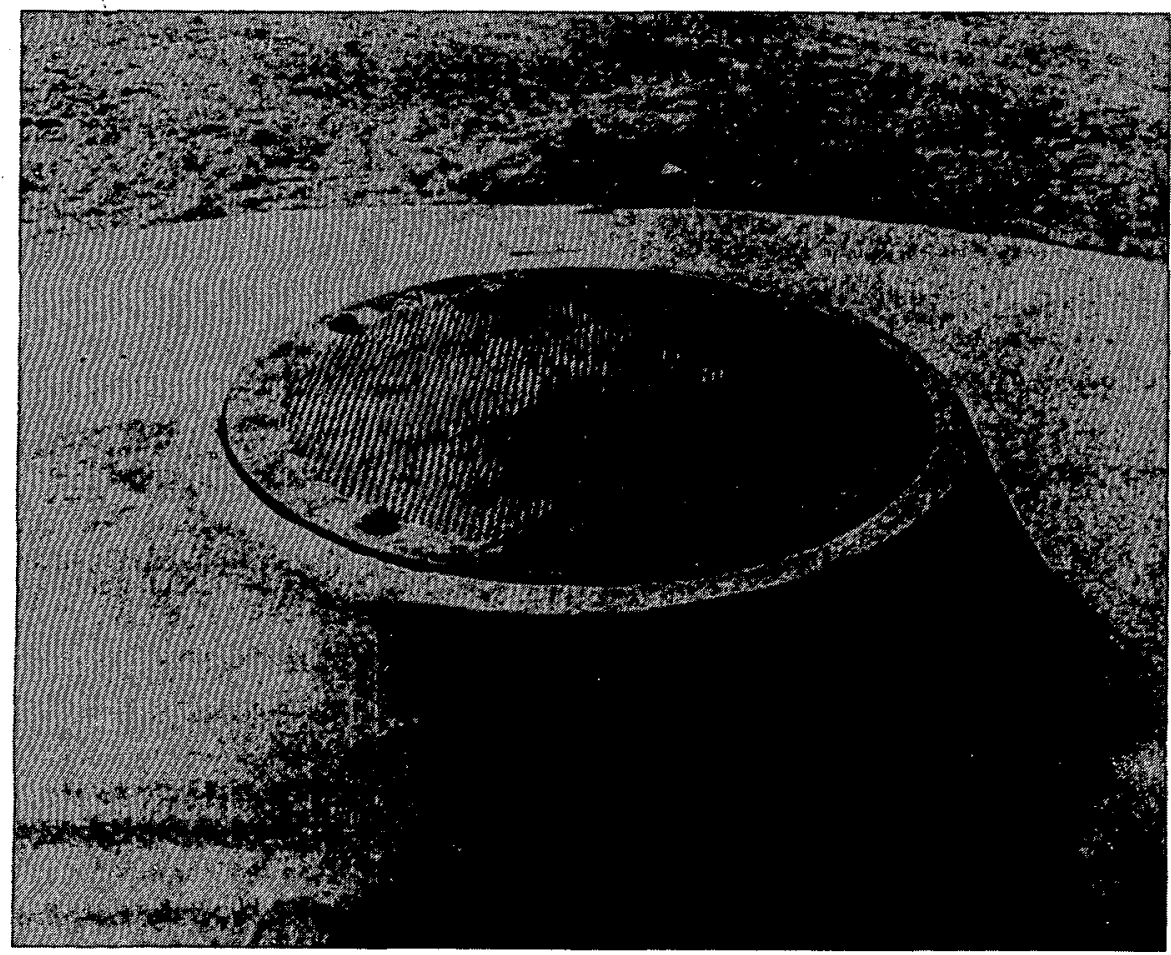

Fig. 2.2-Aerodynamic mound with sleve-plate cover (8002).

the slow-fill chamber. A seventh ground baffle gauge was located outside the structure to record the incident pressure wave. Location of these alr-pressure gauges was about the same in both shelters, and their locations are shown in Figs. 2.1a and 2.1b.

\subsubsection{Dynamic Pressure-Time Gauge}

The dynamic pressure just inside the door of the fast-fill chamber was measurea by a BRL $Q$ gauge $5 \mathrm{ft}$ above the floor and $2 \mathrm{ft}$ from the wall in both structures. In shot 1 the sensing element of the gauge was approximately $5 \mathrm{ft}$ inside the door (Fig. 2.3), and in shot 2 it was $7 \mathrm{ft}$ from the door (Fig. 2.4).

\subsubsection{Alr-Temperature Measurements}

In shot 2 personnel of CETG Project 39.3 (WT -1502) from the Naval Radiation Defense Laboratory installed three air-temperature measuring devices (Fig. 2.5) in each chamber of structure 8002. Their locations are shown in Fig. 2.4. All gauges were 4 ft above the floor.

\subsubsection{Radiation Dosimetry}

(a) Dosimeters. The entryway and inner chambers of both the structures were instrumented with several types of radiation detectors by CETG Projects 39.1, 39.1a, and 39.1b. These included $11 \mathrm{~lm}$ badges, sulfur and gold folls, and chemical dosimeters. The detalls of location and the results are the subject of separate reports (WT-1466, WT-1471, and WT -1500 ), and data from only those dosimeters of interest to this project will be reported subsequently in Secs. 3.3.1(c) and 3.3.2(c).

(b) Radiation Telemetering Detector. Radiation telemetering instruments were placed in the fast-fill chamber and outside both shelters by personnel of CETG Project 39.8 (WT-1509). The location inside the fast-fill room is shown in Fig. 2.4. 


\section{1}
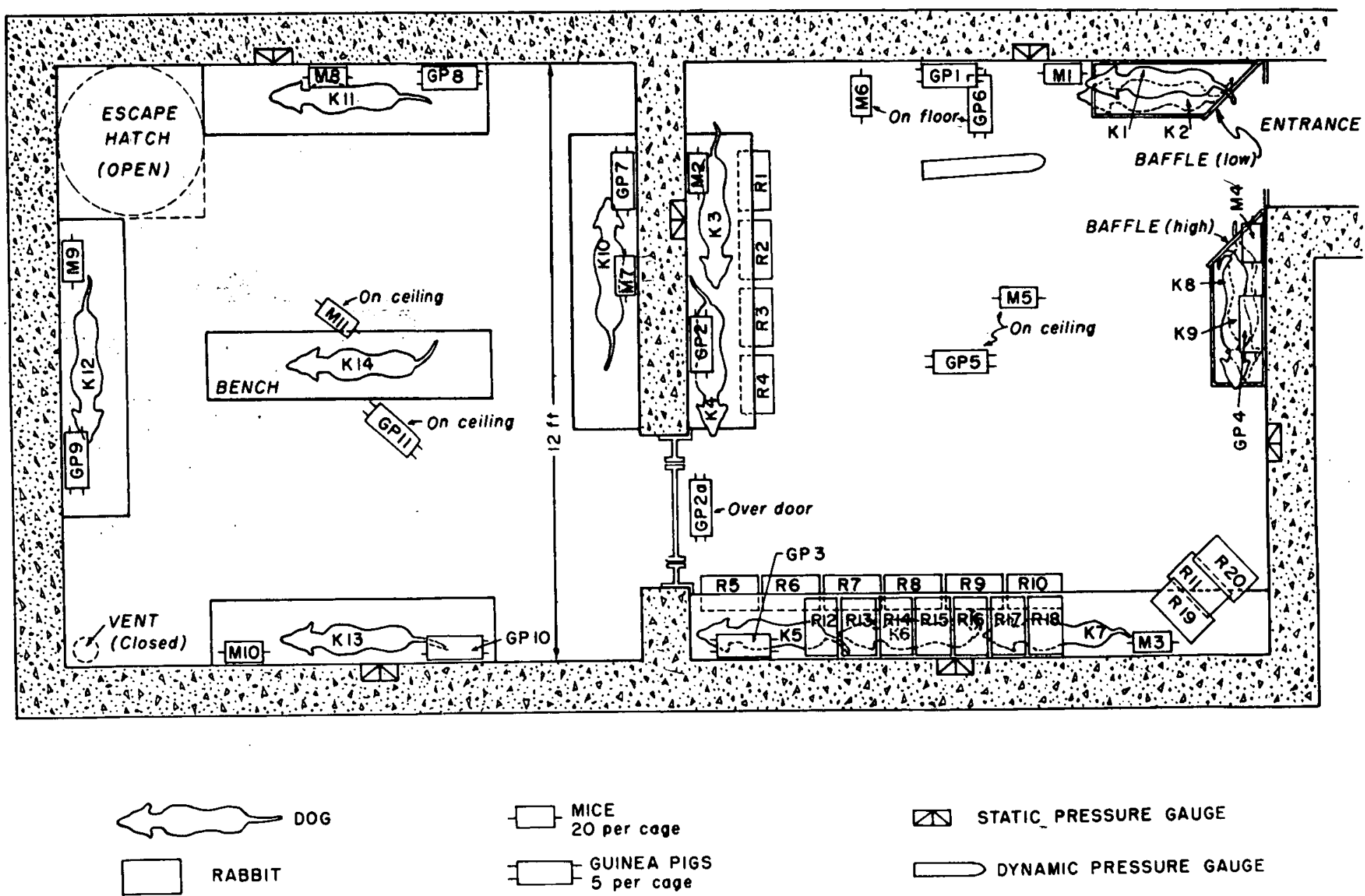

DT STATIC PRESSURE GAUGE 

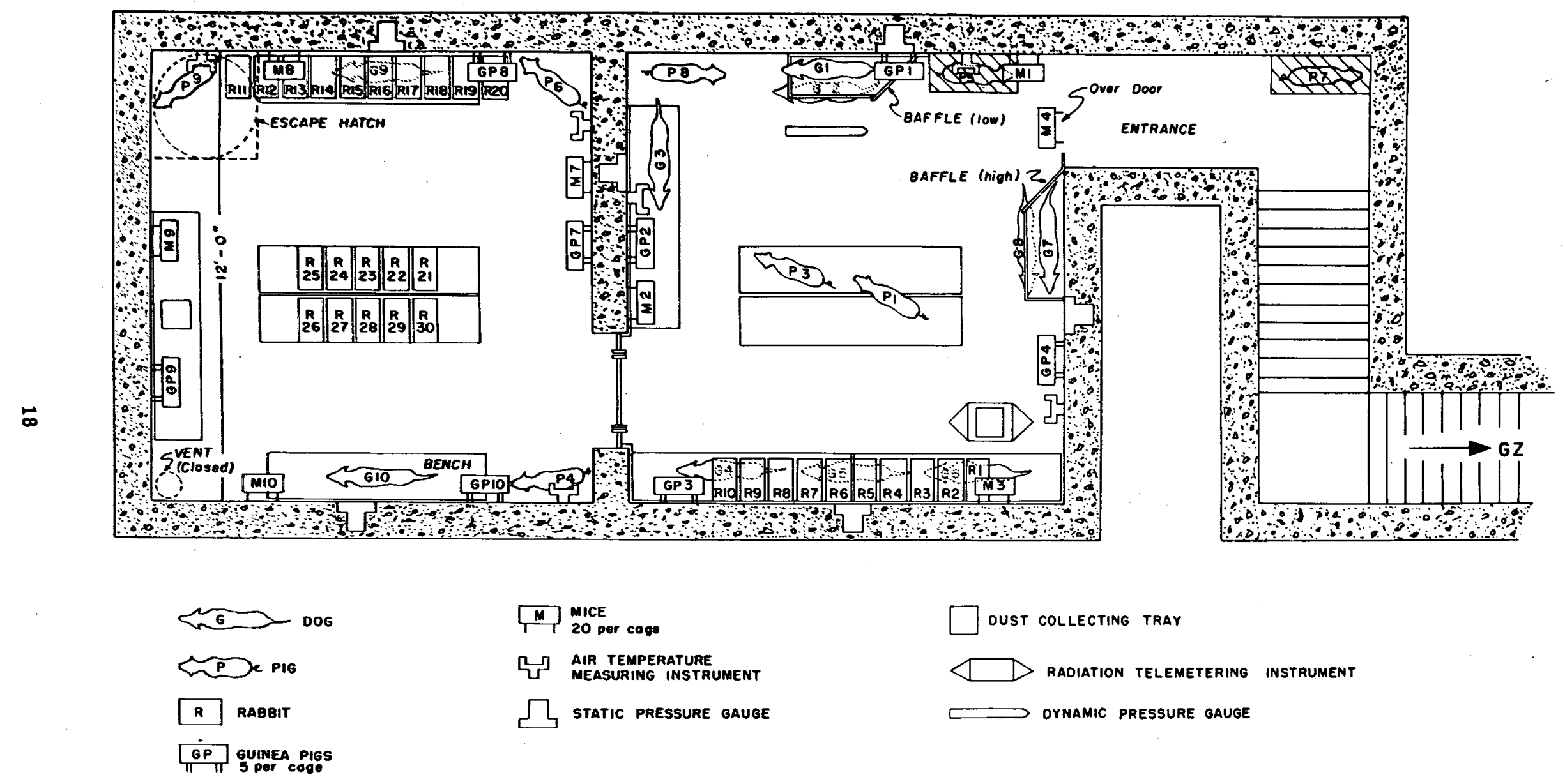

TMICE Mer coge

凹 AIR TEMPERATURE

$\sqrt{\zeta}$ STATIC PAESSURE GAUGE

Fig. 2.4-Location of animals and instruments in shelter 8002 . $\square$ DUST COLLECTING TRAY

$\longrightarrow$ RADIATION TELEMETERING INSTRUMENT

$\longrightarrow$ oYNamic PRESSURE gauge

\section{GP 5 GUINEA PIGS}

a. 


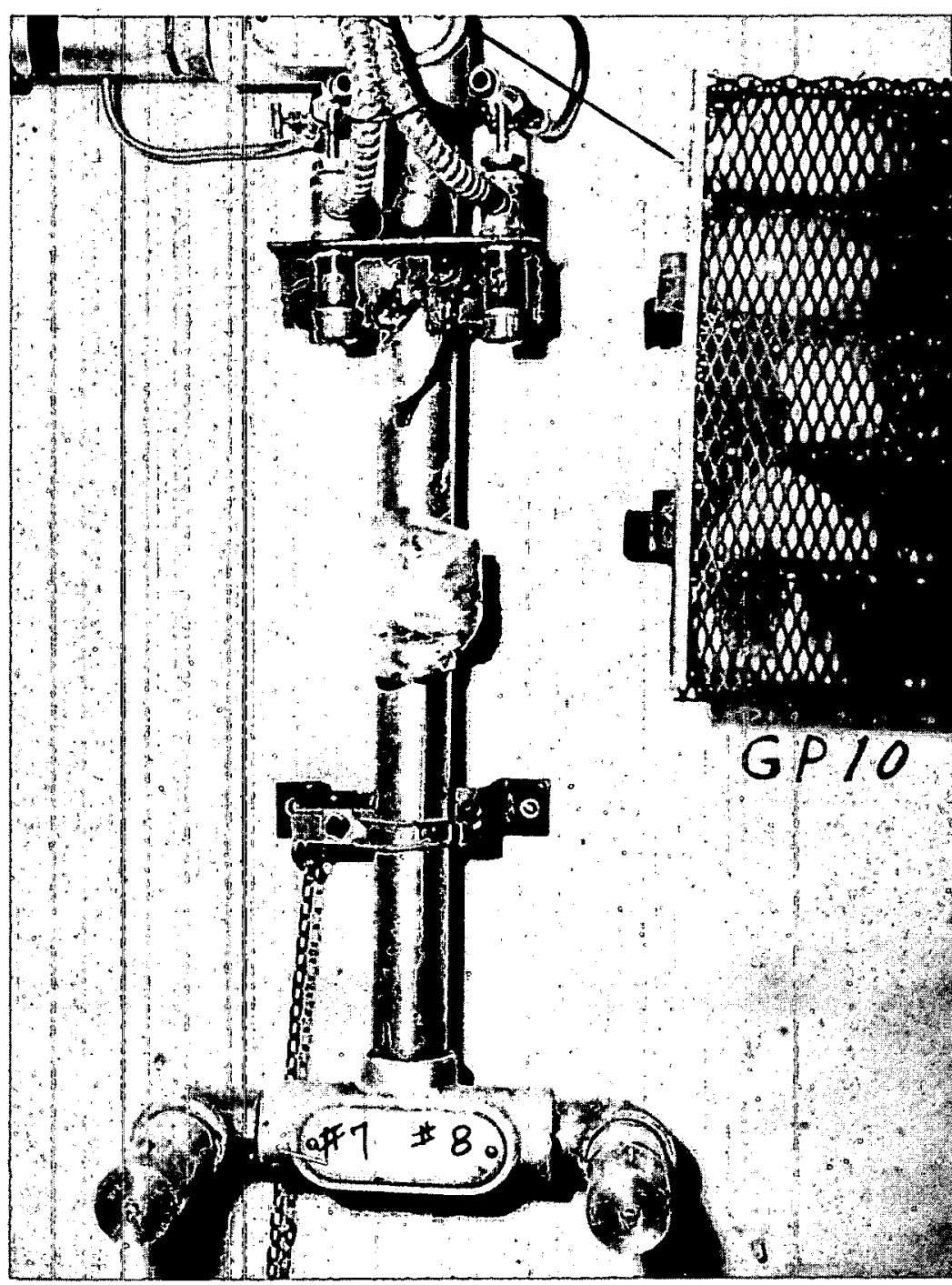

Fig. 2.5-Air-temperature measuring apparatus and guinea pig cage.

\subsubsection{Dust Collectors}

A dust-collecting tray was placed in each of the chambers of structure 8002 . They were located on the telemetering device in the fast-fill room and on the bench along wall 9 in the slow-fill side of the structure (Fig. 2.4).

\subsection{EXPERIMENTAL ANIMALS}

A total of 24 dogs, 50 rabbits, 100 guinea pigs, and 380 mice were used in the two field experiments. The number used in each shelter and the average body weights are given in Table 2.1. In addition, this project assessed for blast damage 8 pigs placed in shelter 8002 primarily for thermal study by CETG Project 39.3 for shot 2 . The relative positions of the animals in the shelters involved in both shots are shown in Figs. 2.3 and 2.4.

\subsubsection{Animal Placements for Primary Blast Effects}

(a) Large Animals. Large-animal species (dogs and pigs) were individually harnessed; the harnesses were snapped to restraining lines. The harness, designed in 1953 by the Lovelace Foundation personnel, was the same type used in previous operations at the Nevada Test Site 
TABLE 2.1-NUMBERS AND WEIGHTS OF THE VARIOUS ANIMAL SPECIES USED IN BOTH SHOTS

\begin{tabular}{llcr}
\multicolumn{1}{c}{ Specles } & Average & \multicolumn{2}{c}{ Number of animals } \\
body weight & Fast-fill & Slow-full \\
\hline Shot 1 (shelter 8001) & & & \\
Dogs & $17.5 \mathrm{~kg}$ & 9 & 5 \\
Rabbits & $2.400 \mathrm{~kg}$ & 20 & 0 \\
Guinea pigs & $0.450 \mathrm{~kg}$ & 35 & 25 \\
Mice & $20.1 \mathrm{~g}$ & 120 & 100 \\
Shot 2 (shelter 8002) & & & \\
Dogs & $19.8 \mathrm{~kg}$ & 8 & 2 \\
Rabbits & $2.660 \mathrm{~kg}$ & 10 & 20 \\
Guinea pigs & $0.449 \mathrm{~kg}$ & 20 & 20 \\
Mice & $19.8 \mathrm{~g}$ & 80 & 80 \\
Pigs & $12.5 \mathrm{~kg}$ & 5 & 3 \\
\hline
\end{tabular}

and can be seen in the various photographs of large animals in place (Figs. 2.6 and 2.7). The only exceptions were the two pigs, one located in the ramp and one just inside the main door, which were exposed in strong diamond-mesh metal cages. Note the end of one such cage in the lower righthand corner of Fig. 2.7.

(b) Small Animals. Rabbits were placed in individual cages (Fig. 2.8) located on or below the dog benches and on frame shelves approximately $6 \mathrm{ft}$ above the floor. Mice and guinea pigs were exposed in specially designed cages, compartmentalized to prevent huddling of the animals. These cages were constructed of heavy diamond-mesh metal of a type used in laboratory blast-tube experiments. Ease of loading was one of the design criteria of these cages. Guinea pig and mouse cages held 5 and 20 animals, respectively. In shot 1 the guinea pig and mouse cages were mounted flush with the walls, celling, or floor (Fig. 2.6); in shot 2 they were extended 8 in. from the wall (Figs. 2.4 and 2.5).

(c) Numbering System of Animals. Animals were numbered according to their location in the shelter. Dogs were numbered consecutively in a counterclockwise direction. Small-animal cages were numbered according to the wall on which they were located. Within each cage the animals were numbered from top to bottom. Tables 2.2 and 2.3 give the numbering system, and locations are noted in Figs. 2.3 and 2.4.

\subsubsection{Animal Placement for Tertiary Blast Effects}

(a) Steel-plate Baffle. To compare the effects of the blast wave entering the fast-fill chamber on dogs with and without wind protective baffles at a given location in the shelter, the following placements were installed. In shot 1 , shelter 8001 , the baffle was a $1 / 2$-in.-steel plate, $36 \times 21$ in., bolted to the wall at a $45^{\circ}$ angle with the vertical. In order to have an appropriate control, a shelf was installed above the baffle to expose an animal without a baffle at the same location.

This particular placement was used on either side of the main entrance. The baffle on wall 4 was above the shelf instead of below as on wall 1. The shelves and baffles, together with the animals in place, can be seen in Figs. 2.6 and 2.8.

(b) Wire-screen Baffle. For shot 2 the baffle and shelves were modified as follows: baffles were of woven wire screen, gauge 4 (diameter $0.204 \mathrm{in}$.), with four holes per square inch. The one on wall 1 was located $4 \mathrm{ft}$ from the doorway and not at the door as in shot 1 (Fig. 2.7). The location of the wire baffle and shelf on wall 4 was identical to that in structure 8001 (Fig. 2.9).

To ensure uniform tethering and to allow displacement should sufficiently high dynamic pressures be obtained, loops of string were incorporated between the restraining leads and the harness snaps. Also, a steel aircraft cable leash was attached to the harness by a ventral snap, with sufficient slack not to interfere with the possible trajectory of the animal, but to ensure his recovery subsequent to any survivable translation. 


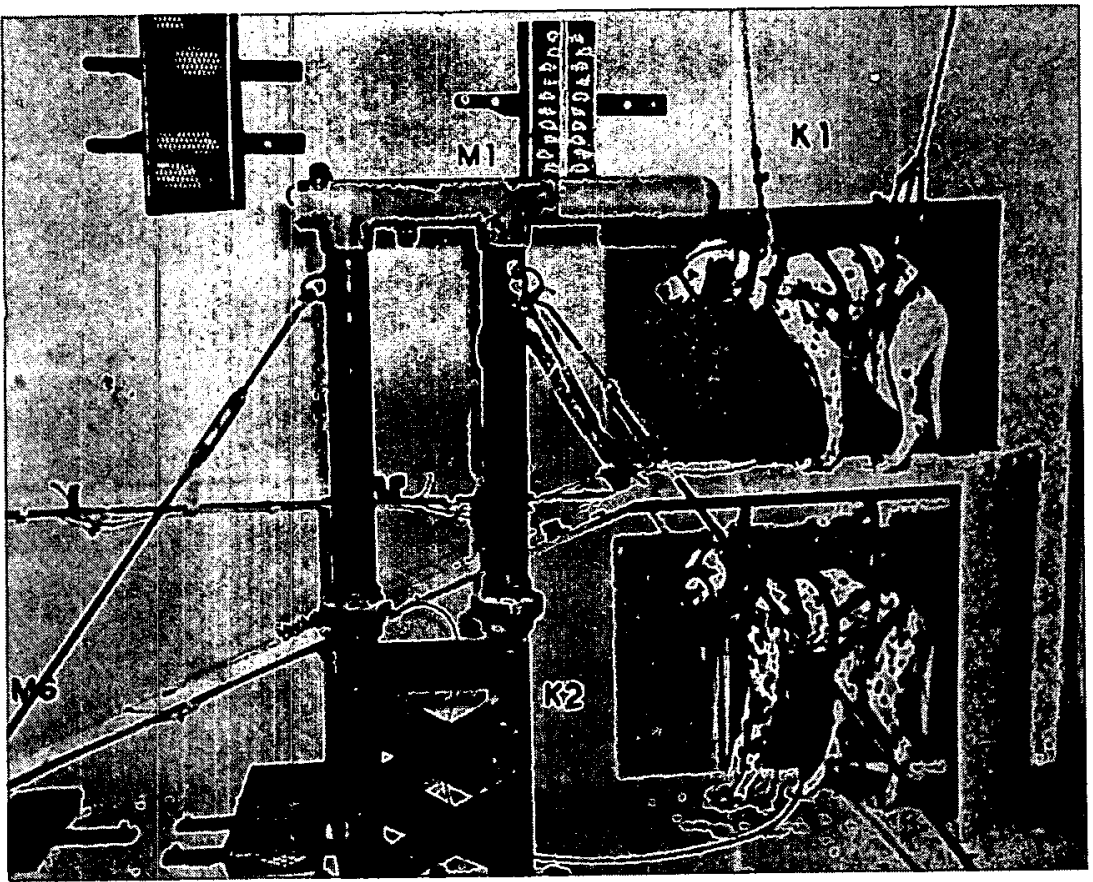

Fig. 2.6-Solid baffle and shelf on wall 1 of shelter 8001 and dynamic pressure gauge.

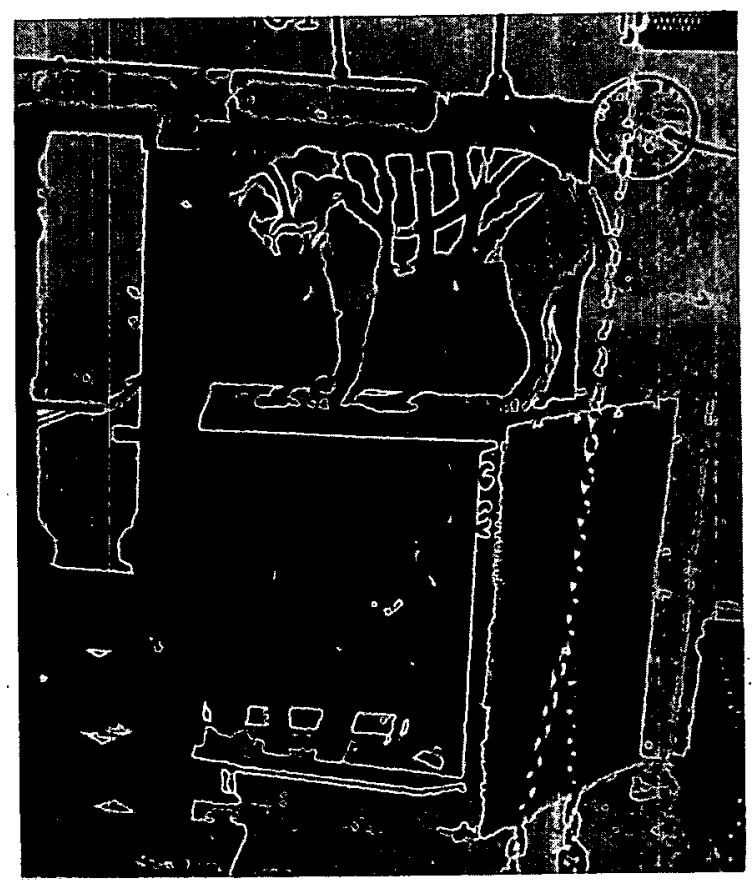

Fig. 2.7-Screen baffle and shelf on wall 1 of shelter 8002 and dynamic pressure gauge. 


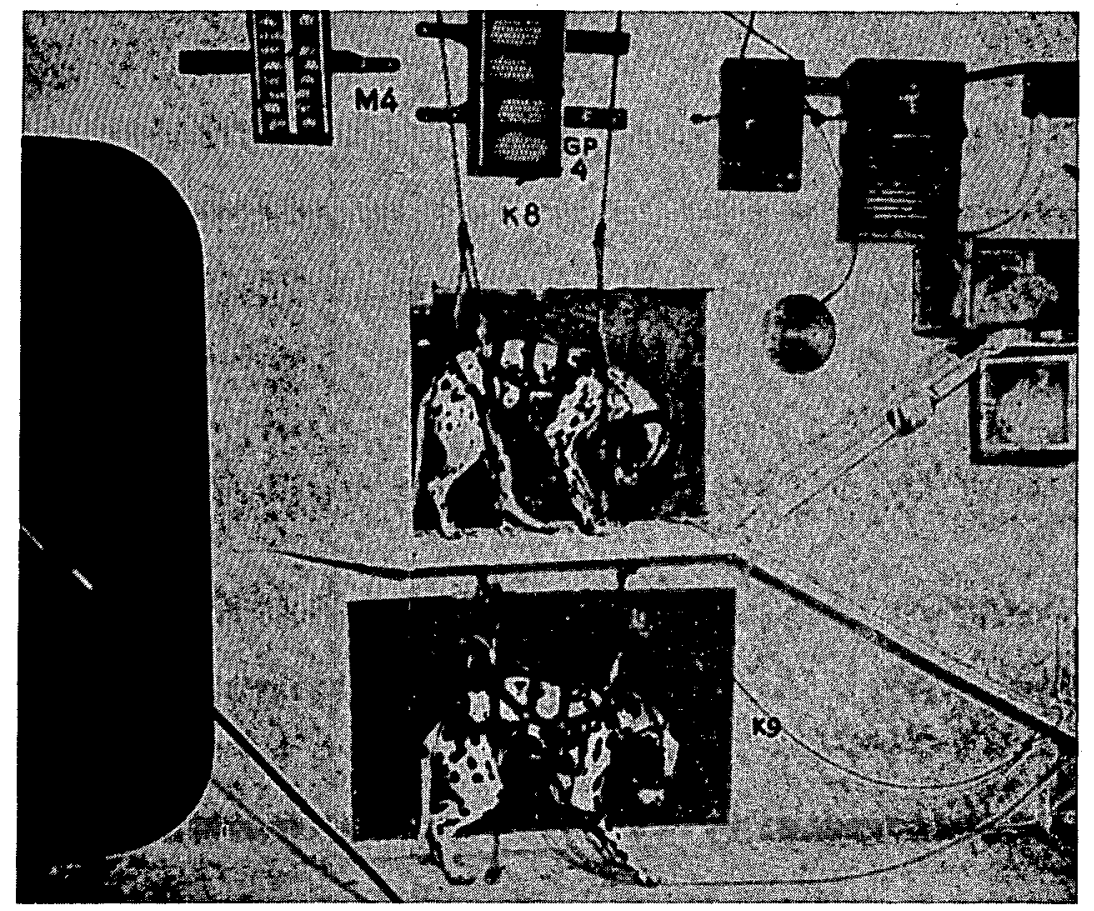

Fig. 2.8-Solid baffle and shelf on wall 4 of shelter 8001 .

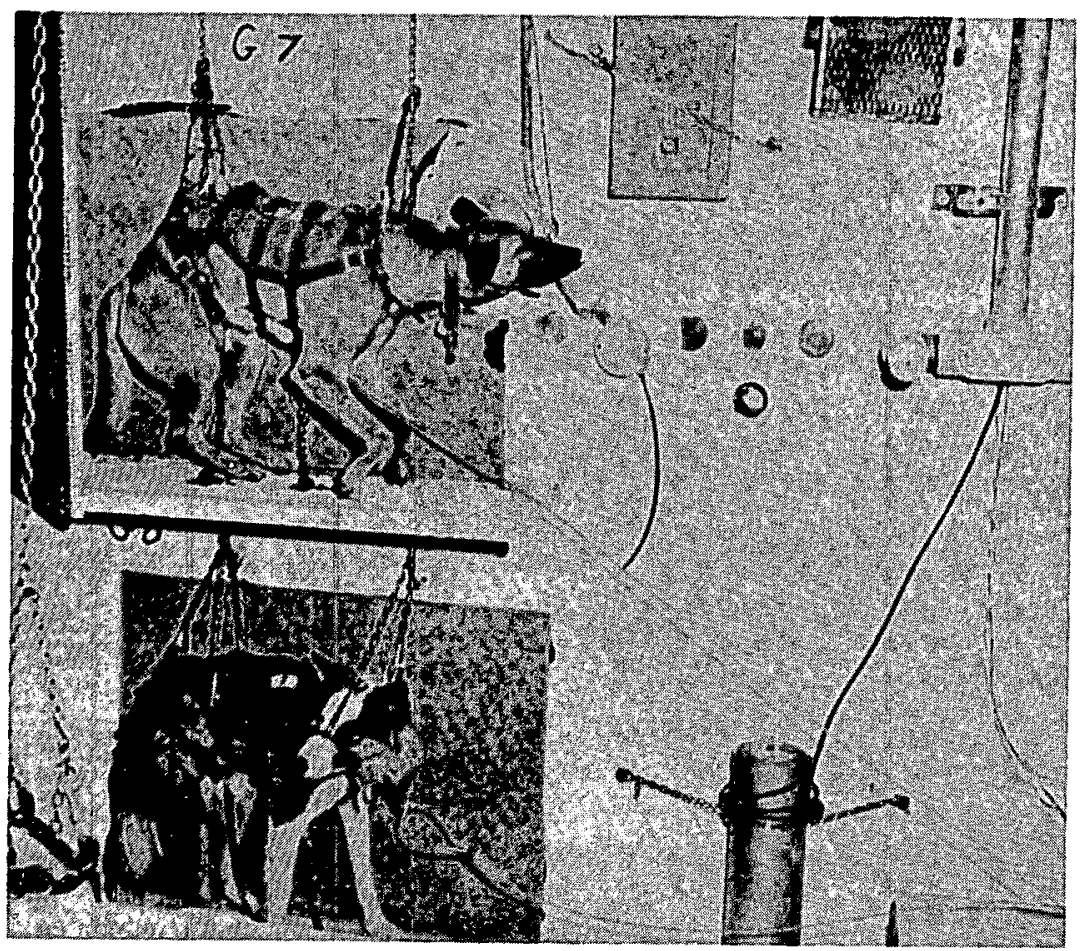

Fig. 2.9-Screen baffle and shelf on wall 4 of shelter 8002 . 
TABLE 2.2-NUMBER SYSTEM AND LOCATION OF ANIMALS PLACED IN SHELTER 8001, SHOT 1

$\therefore$

\begin{tabular}{|c|c|c|c|}
\hline Specles & Location & $\begin{array}{l}\text { Number of } \\
\text { animals }\end{array}$ & Animal No.* \\
\hline \multirow[t]{4}{*}{ Dog 8} & Wall 1 & 2 & $\mathrm{~K}-1,2$ \\
\hline & Wall 2 & 2 & 3,4 \\
\hline & Wall 3 & 3 & $5,6,7$ \\
\hline & Wall 4 & 2 & 8,9 \\
\hline \multirow[t]{4}{*}{ Rabbits } & Wall 2 , below bench & 4 & $\mathrm{R}-1,2,3,4$ \\
\hline & Wall 3, below bench & 6 & $5,6,7,8,9,10$ \\
\hline & Wall 3, shelf & 7 & $\begin{array}{c}12,13,14,15,16 \\
17,18\end{array}$ \\
\hline & $\begin{array}{l}\text { Corner wall } 3 \text { and } 4 \\
\text { on camera mount }\end{array}$ & 3 & $11,19,20$ \\
\hline \multirow[t]{7}{*}{ Guinea pigs } & Wall 1 & $\mathbf{5}$ & GP-1, 1-5 \\
\hline & Wall 2 & 5 & $2,1-5$ \\
\hline & Wall 2 & 5 & $2 a, 1-5$ \\
\hline & Wall 3 & 5 & $3,1-5$ \\
\hline & Wall 4 & 5 & $4,1-5$ \\
\hline & Celling (5) & 5 & $5,1-5$ \\
\hline & Floor (6) & 5 & $6,1-5$ \\
\hline \multirow[t]{6}{*}{ Mice } & Wall 1 & 20 & $\mathbf{M}-1$ \\
\hline & Wall 2 & 20 & 2 \\
\hline & Wall 3 & 20 & 3 \\
\hline & Wall 4 & 20 & 4 \\
\hline & Celling (5) & 20 & 5 \\
\hline & Floor (6) & 20 & 6 \\
\hline \multirow[t]{5}{*}{ Dogs } & Wall 7 & 1 & $\mathbf{K}-10$ \\
\hline & Wall 8 & 1 & 11 \\
\hline & Wall 9 & 1 & 12 \\
\hline & Wall 10 & 1 & 13 \\
\hline & $\begin{array}{l}\text { On bench, center } \\
\text { of room }\end{array}$ & 1 & 14 \\
\hline Rabbits & None & & \\
\hline \multirow[t]{5}{*}{ Guinea pigs } & Wall 7 & 5 & GP-7, 1-5 \\
\hline & Wall 8 & 5 & $8,1-5$ \\
\hline & Wall 9 & 5 & $9,1-5$ \\
\hline & Wall 10 & 5 & $10,1-5$ \\
\hline & Celling (1-1) & 5 & $11,1-5$ \\
\hline \multirow[t]{5}{*}{ Mice } & Wall 7 & 20 & $\mathbf{M}-7$ \\
\hline & Wall 8 & 20 & 8 \\
\hline & Wall 9 & 20 & 9 \\
\hline & Wall 10 & 20 & 10 \\
\hline & Celling & 20 & 11 \\
\hline
\end{tabular}

*Mice are not individually numbered. 
TABLE 2.3-NUMBER SYSTEM AND LOCATION OF ANIMALS PLACED IN SHELTER 8002, SHOT 2

\begin{tabular}{|c|c|c|c|}
\hline Species & Location & $\begin{array}{l}\text { Number of } \\
\text { animals }\end{array}$ & Animal No.* \\
\hline \multirow[t]{4}{*}{ Dogs } & Wall 1 & 2 & $\mathrm{G}-1,2$ \\
\hline & Wall 2 & 1 & 3 \\
\hline & Wall 3 & 3 & $4,5,6$ \\
\hline & Wall 4 & 2 & 7,8 \\
\hline Rabbits & Wall 3, shelf & 10 & $\begin{array}{c}\mathrm{R}-1,2,3,4,5,6 \\
7,8,9,10\end{array}$ \\
\hline \multirow[t]{4}{*}{ Gulnea plgs } & Wall 1 & 5 & GP-1, 1-5 \\
\hline & Wall 2 & 5 & $2,1-5$ \\
\hline & Wall 3 & 5 & $3,1-5$ \\
\hline & Wall 4 & 5 & $4,1-5$ \\
\hline \multirow[t]{4}{*}{ Mice } & Wall 1 & 20 & M-1 \\
\hline & Wall 2 & 20 & 2 \\
\hline & Wall 3 & 20 & 3 \\
\hline & Wall 4 & 20 & 4 \\
\hline \multirow{2}{*}{ Dogs } & Wall 8 & 1 & $Q-9$ \\
\hline & Wall 10 & 1 & 10 \\
\hline \multirow[t]{2}{*}{ Rabbits } & Wall 8, shelf & 10 & $\begin{array}{c}\mathrm{R}-11,12,13,14,15,16 \\
17,18,19,20\end{array}$ \\
\hline & $\begin{array}{l}\text { On bench, center } \\
\text { of room }\end{array}$ & 10 & $\begin{array}{c}21,22,23,24,25,26 \\
27,28,29,30\end{array}$ \\
\hline \multirow[t]{4}{*}{ Guinea pigs } & Wall 7 & 5 & GP-7, 1-5 \\
\hline & Wall 8 & 5 & $8,1-5$ \\
\hline & Wall 9 & 5 & $9,1-5$ \\
\hline & Wall 10 & 5 & $10,1-5$ \\
\hline \multirow[t]{4}{*}{ Mice } & Wall 7 & 20 & $\mathbf{M - 7}$ \\
\hline & Wall 8 & 20 & 8 \\
\hline & Wall 9 & 20 & 9 \\
\hline & Wall 10 & 20 & 10 \\
\hline
\end{tabular}

*Mice are not Individually numbered.

\subsection{GENERAL REMARKS}

\subsubsection{Training of Animals}

Before each experiment all the dogs were trained to the harness and the muzzle and to being restrained as in the shelters in order that they would become accustomed to the procedure. In addition, several dry runs were carried out to facilitate rapid placement and recovery of animals.

\subsubsection{Pathological Examination}

Following the tests each animal was thoroughly examined for evidence of blast damage using conventional autopsy techniques. Dogs and rabbits were anesthetized by intravenous doses of Nembutal solution $(60 \mathrm{mg} / \mathrm{cc})$. The femoral artery was then cannulized, and the animal was exsanguinated. To avoid entry of air into the venous circulation, examination was not started until cardiac arrest had been achieved. The body and its contained organs were then systematically examined, and a protocol of findings was compiled for each animal. Sections, when appropriate, were taken for histologic study, and color photographs were made of all significant lesions. Before the thorax was opened, the trachea was clamped below the larynx. The lungs were then removed, together with the heart, in an inflated state and examined superficially. The tracheal clamp was removed, and each lung was dissected from the attached tissue 
and weighed. Lungs were then reinflated to approximately normal size by gentle perfusion with fixative solution, and the bronchi were clamped off. Sometime later the fixed lungs were sectioned and examined microscopically.

Tissue samples were generally fixed in both Helly's solution and buffered 10 per cent formalin solution. Lungs, brain, and internal ears, however, were fixed only in buffered formalin. Eyes were fixed in toto in Helly's solution; penetration of the fixative solution was effected by slicing off a thin portion of the globe on either side with a razor. This procedure did not appreciably disturb the retina, and later the globe was properly trimmed and blocked for processing.

The internal auditory apparatus was removed in toto by sawing a block from the petrous portion of the temporal bone, so as to include the internal and external auditory canals, and the entire middle ear. The roof of the tympanic cavity was removed, exposing the ossicles and the rear of the tympanic membrane. The entire osseous block was then fixed in buffered formalin and preserved for later examination with a dissection microscope. The eardrums of mice were not examined.

Fixed tissue specimens were later processed, according to customary histological techniques, and slides were examined with hematoxylin-eosin and Masson trichrome stains.

\section{REFERENCE}

1. C. S. White, T. L. Chiffelle, D. R. Richmond, W. H. Lockyear, I. G. Bowen, V. C. Goldizen, H. W. Merideth, D. E. Kilgore, B. B. Longwell, J. T. Parker, F. Sherping, and M. E. Cribb, The Blological Effects of Pressure Phenomena Occurring Inside Protective Shelters Following Nuclear Detonation, Operation Teapot Report, WT-1179, October 1956. 


\section{Chapter 3}

\section{RESULTS}

\subsection{GENERAL OBSERVATIONS}

\subsubsection{Shot 1}

At approximately $\mathrm{H}+3 \mathrm{hr}$ an early survey party entered the shelter to assess blast damage and to take postshot documentary photographs. Both inner chambers were covered with dust and small stones which blew in through the main entryway and the escape hatch. Animal K-1 was found severely injured but alive lying in the center of the room, as seen in Fig. 3.1. All

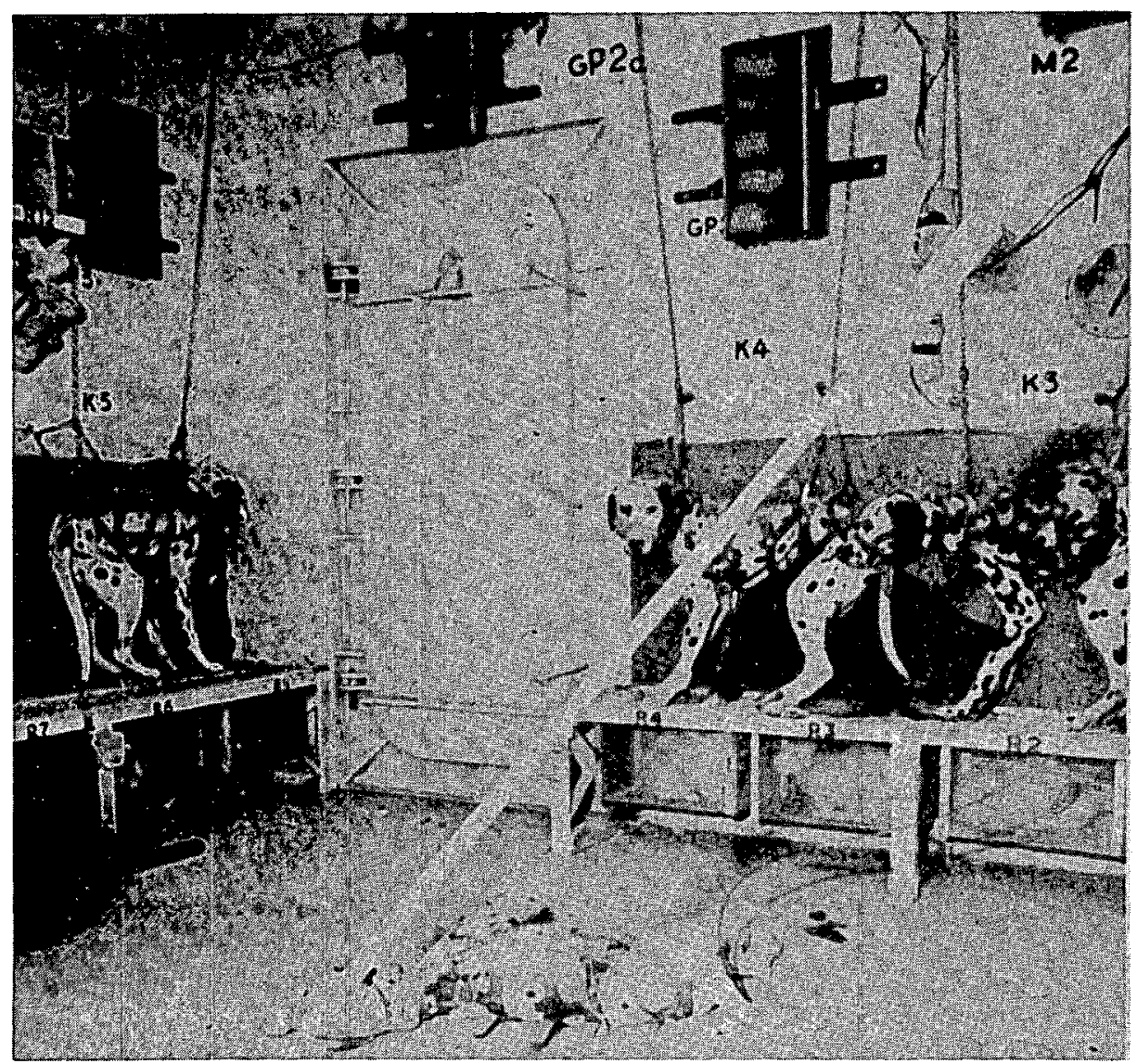

Fig. 3.1 - Location of dog K-1 postshot. 
other dogs were in their original positions. Baffles, shelves, benches, and small-animal cages were all found intact. Outside the shelter a large radial crack was observed in the aerodynamic mound (Fig. 3.2a).

Recovery of the animals from the shelter was made, using a "six-by" truck as a recovery vehicle at $\mathrm{H}+3 \frac{1}{2} \mathrm{hr}$. Radiation levels, measured with Rad-Safe furnished survey meters, were about $8 \mathrm{r} / \mathrm{hr}$ outside the shelter and less than $5 \mathrm{mr} / \mathrm{hr}$ inside.

\subsubsection{Shot 2}

The early postshot photography and anirnal recovery (including the eight swine of CETG Project 39.3) closely paralleled the shot 1 participation. Dog G-1 was found standing in the fast-fill chamber near the partition door uninjured, having been blown from shelf 1 (Fig. 3.3). There was no evidence that this animal struck wall 2 from inspection of the wall. All the other larger animals (dogs and swine) were in place. The small-animal cages, baffles, and shelves withstood the blast satisfactorily. Recovery procedures and transportation' of experimental animals to base were accomplished without incident.

The aerodynamic mound was found cracked, and a portion of one of the $1 / 8$-in.-thick plates of the sieve plate was partially folded back (Fig. 3.2b).

\subsection{INSTRUMENTATION}

\subsubsection{Pressure-Time Records}

The pertinent parameters of the blast wave as recorded within the chambers of structures 8001 and 8002 are given in Table 3.1. The wave forms recorded in the different chambers are reproduced in Figs. 3.4 and 3.5. The average peak overpressure in the fast-fill room on shot 1 was $25.5 \mathrm{psi}$ and of $269 \mathrm{msec}$ duration. On shot 2 it was slightly higher, $30.3 \mathrm{psi}$, having a duration of $300 \mathrm{msec}$. The respective times to peak pressure were 53 and $65 \mathrm{msec}$.

An average peak pressure of $9.5 \mathrm{psi}$ was reached in $119 \mathrm{msec}$ in the slow-fill chamber (8001); the duration of the positive phase was $330 \mathrm{msec}$. On the second shot, however, the overpressure reached only $4.1 \mathrm{psi}$ in $203 \mathrm{msec}$; the pressure remained above the preshot ambient pressure for $512 \mathrm{msec}$.

On the first shot all pressure-time gauges functioned except No. 10, which recorded just the peak pressure. On the second shot gauge 2 recorded the first portion of the wave, and gauge 4 registered peak pressure only.

\subsubsection{Dynamic Pressure-Time Measurements}

The $Q$ measurements taken in the two structures are included in Table 3.1. Only the peak value of $10.5 \mathrm{psi}$ was recorded in shelter 8001 . The peak value recorded in shelter 8002 was $2.0 \mathrm{psi}$.

\subsubsection{Air-temperature Measurements}

All attempts to measure the air temperature inside shelter 8002 by CETG Project 39.3 were unsuccessful.

\subsubsection{Dust Collectors}

The preliminary data obtained from the dust collectors are available in ITR-1447, and the final evaluation will be documented in WT-1447.

\subsubsection{Radiation Dosimetry}

(a) Dosimeters. The locations and types of measurements made by the different radiation detectors pertinent to this project are illustrated in Figs. 3.6 and 3.7. The results will be discussed in connection with their biological effects in Secs. 3.3.1(c) and 3.3.2(c). 


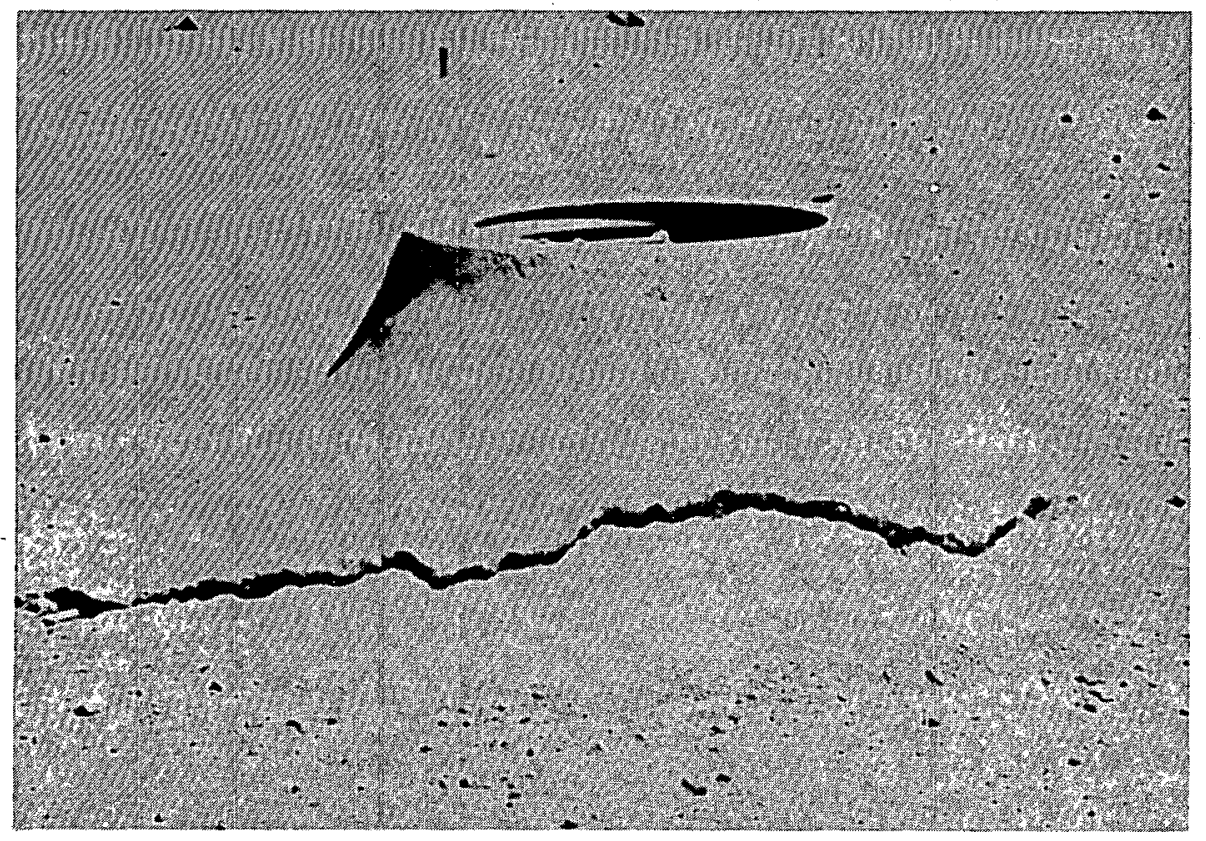

Fig. 3.2a-Damage to aerodynamic mound above shelter 8001 .

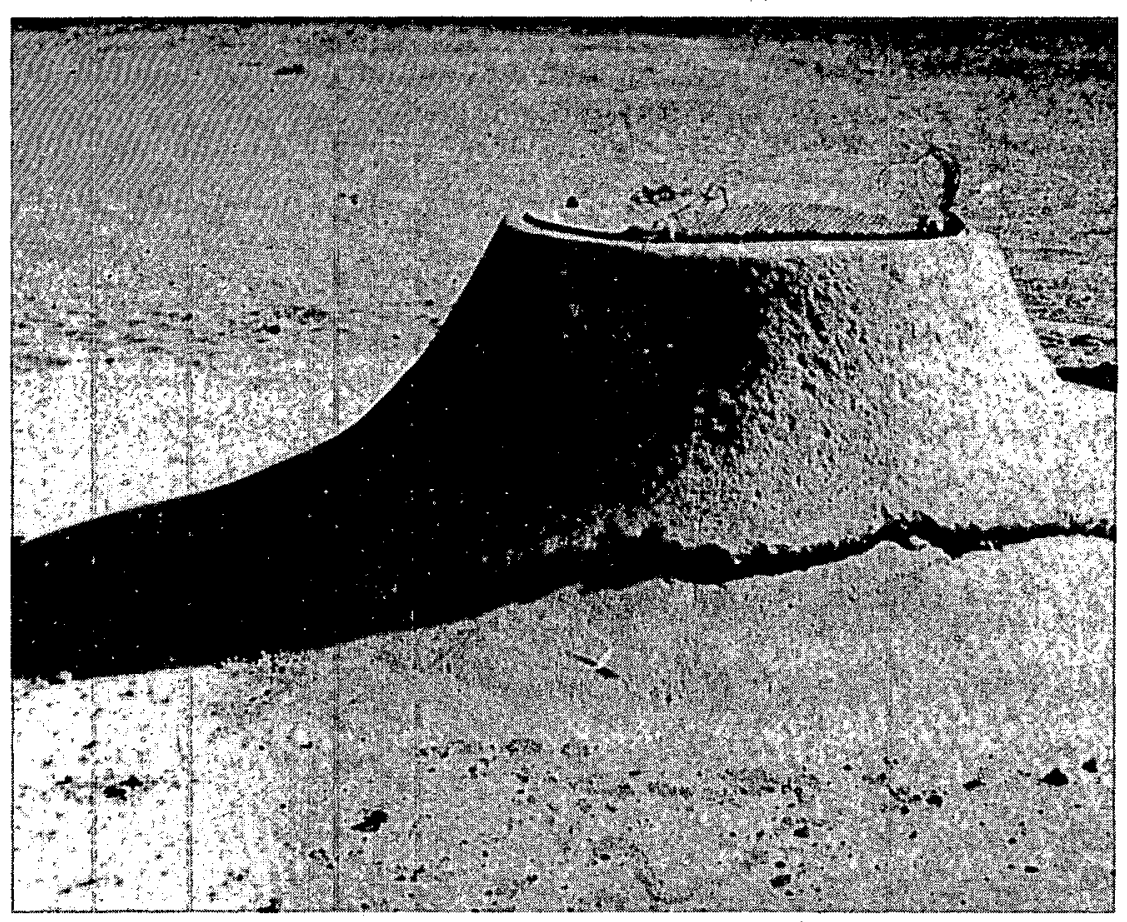

Fig. 3.2b-Damage to aerodynamic mound above shelter 8002 . 


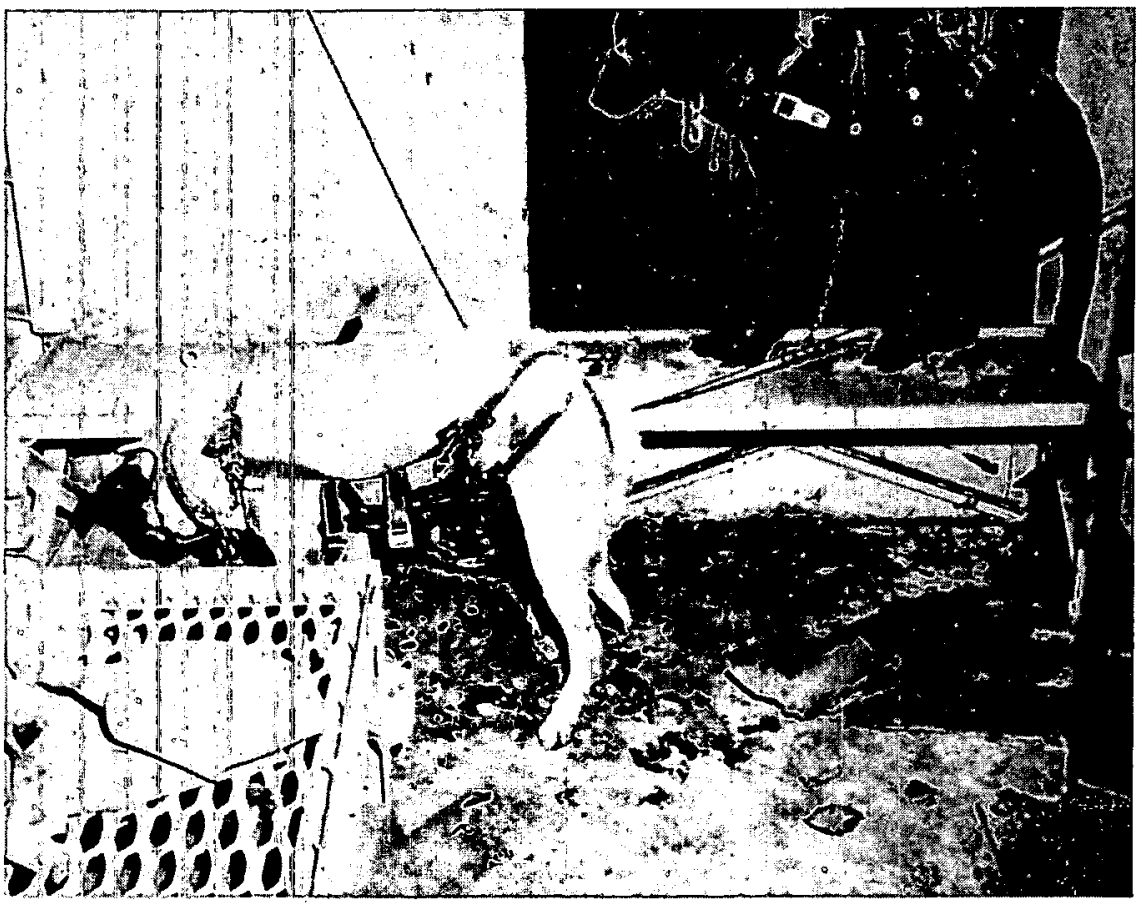

Fig. 3.3-Location of dog G-1 postshot, view from entryway.

(b) Radiation Telemetering Detectors. The telemetering instrument outside structure 8001 functioned properly and aided in planning the time of recovery. The three other detectors placed in the fast-fill chambers of each shelter and outside structure 8002 failed. For further details see WT-1509.

\subsection{PATHOLOGY}

\subsubsection{Shot 1}

(a) Mortality. Two guinea pigs (6-3 and 3-1) were dead upon recovery. Of the three mice found dead, two were from cage 2 , and one was from cage 1 . The dead mice in cage 2 were no doubt killed by dog K-1 that struck wall 2 and crushed portions of the mouse cage. In the postshot photograph of wall 2, blood and excrement can be seen on the wall around the upper portion of mouse cage 2 (Fig. 3.8).

(b) Post-mortem Findings. All animals were sacrificed for post-mortem studies except dogs $\mathrm{K}-8$ and $\mathrm{K}-14$ and 110 mice (10 from each cage). Blast injuries recorded at post-mortem are summarized in Table 3.2. Detailed tabulations for each species exposed in shelter 8001 are in Appendix A. The only remarkable pathological lesions other than eardrum rupture and slight lung hemorrhages were found in $\operatorname{dog} \mathrm{K}-1$, who was translated. This animal was paralyzed caudally owing to fracture of the lumbar vertebra and severed spinal cord (Fig. 3.9a). The spleen and liver were found ruptured with a resulting hemoperitoneum. Also noted in the abdomen was a disrupted lining of the urinary bladder (Fig. 3.9b). Intrathoracically, the heart myocardium was lacerated and contused in the interventricular septum with an associated hemopericardium. Several petechia hemorrhages were found in the lungs of K-1 and also in K-3 and K-9. As can be seen from Table 3.2, 5 guinea pigs and 5 rabbits sustained pulmonary hemorrhages. Except for guinea pig 2a-5, which had a moderate degree of lung hemorrhage, all others had slight amounts. Sixteen of the mice from cages 2,4 , and 5 exhibited slight to moderate degrees of lung hemorrhage. Only one animal (GP-11-4) in the slow-fill room had pulmonary lesions.

(c) Ionizing-radiation Effects. No symptoms of radiation effects were recorded in the 110 mice and 2 dogs (K-8 and K-14) observed for 30 days postshot. The results are in agreement 
TABLE 3.1 - PARAMETERS OF THE BLAST WAVE INSIDE SHELTERS 8001 AND 8002

\begin{tabular}{|c|c|c|c|c|c|c|}
\hline $\begin{array}{c}\text { Gauge } \\
\text { location }\end{array}$ & $\begin{array}{l}\text { Peak over- } \\
\text { pressure, } \\
\text { psi }\end{array}$ & $\begin{array}{c}\text { Time to } \\
\text { peak } \\
\text { pressure, } \\
\text { msec }\end{array}$ & $\begin{array}{c}\text { Duration of } \\
\text { positive phase, } \\
\text { msec }\end{array}$ & $\begin{array}{c}\text { Peak } \\
\text { negative } \\
\text { pressure, } \\
\text { psi }\end{array}$ & $\begin{array}{c}\text { Time to peak } \\
\text { negative } \\
\text { pressure, } \\
\text { msec }\end{array}$ & $\begin{array}{l}\text { Duration of } \\
\text { entire wave } \\
\text { sec }\end{array}$ \\
\hline \multicolumn{7}{|l|}{ Structure 8001} \\
\hline Wall 1 & 25.7 & 51 & 292 & -3.4 & 406 & 2.32 \\
\hline Wall 2 & 27.0 & 45 & 240 & -3.5 & 354 & 2.71 \\
\hline Wall 3 & 23.8 & 50 & 245 & -6.3 & 399 & 2.66 \\
\hline Wall 4 & 25.6 & 66 & 297 & -3.2 & 420 & 2.60 \\
\hline Average & 25.5 & 53 & 269 & -4.09 & 394 & 2.58 \\
\hline$Q_{1} * \dagger$ & 10.5 & & & & & \\
\hline \multicolumn{7}{|l|}{ Slow-fill } \\
\hline $\begin{array}{l}\text { Wall } 8 \\
\text { Wall } 10 \dagger\end{array}$ & $\begin{array}{r}9.0 \\
10.0\end{array}$ & 119 & 330 & -3.01 & 472 & 2950 \\
\hline Average & 9.5 & & & & & \\
\hline \multicolumn{7}{|l|}{ Structure 8002} \\
\hline Wall I & 30.4 & 68 & 305 & -3.5 & 464 & 3.44 \\
\hline Wall $2 \ddagger$ & 30.2 & 59 & & & & \\
\hline Wall 3 & 30.5 & 68 & 294 & -3.3 & 403 & \\
\hline Wall $4 \uparrow$ & 30.0 & & & & & \\
\hline Average & 30.3 & 65 & 300 & & & \\
\hline $\mathrm{Q}_{2} \S$ & 2.0 & & & & & \\
\hline \multicolumn{7}{|l|}{ Slow-fill } \\
\hline Wall 8 & 4.1 & 194 & 517 & -2.3 & 1097 & 3.42 \\
\hline Wall 10 & 4.1 & 212 & 506 & -2.3 & 1254 & 3.19 \\
\hline Average & 4.1 & 203 & 512 & -2.3 & 1176 & 3.31 \\
\hline
\end{tabular}

* Located $5 \mathrm{ft}$ from main doorway, $5 \mathrm{ft}$ above floor, and $2 \mathrm{ft}$ from wall 1 (parallel with wall).

$\dagger$ Peak pressure only.

$\ddagger$ Peak pressure and time only.

$\S$ Located $7 \mathrm{ft}$ from main doorway, $5 \mathrm{ft}$ above floor, and $2 \mathrm{ft}$ from wall 1 (parallel with wall).

with the measurements taken in the two chambers by the various radiation detectors. From Fig. 3.6 it can be seen that the radiation levels (gamma) ranged between 0.50 and $1.2 \mathrm{r}$ in the fast-fill chamber, and, away from beneath the escape hatch in the slow-fill side, the radiation levels ranged between 1.30 and $2.5 \mathrm{r}$. Fast-neutron flux intensities were too low to count in both chambers (sulfur detectors). Gold foils recorded low slow-neutron fluxes of $2.14 \times 10^{9}$ and $4.89 \times 10^{8} \mathrm{n} / \mathrm{cm}^{2}$ for the fast-fill and slow-fill rooms, respectively. (Assuming an RBE of 1 , this would amount to an insignificant dose of less than $5 \mathrm{rem}$.)

(d) Thermal Effects. No thermal effects of any kind were noted on any of the experimental animals exposed inside shelter 8001 .

(e) Dust. There were no dust collectors within shelter 8001. At autopsy no detectable amounts of dust were present in the respiratory passageways of animals.

\subsubsection{Shot 2}

(a) Mortality. Fourteen of the mice in cage 1 and one from cage 2 were killed by the blast. The only other blast fatality was pig 7 , located in a cage secured in the entryway ramp. 


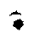

e
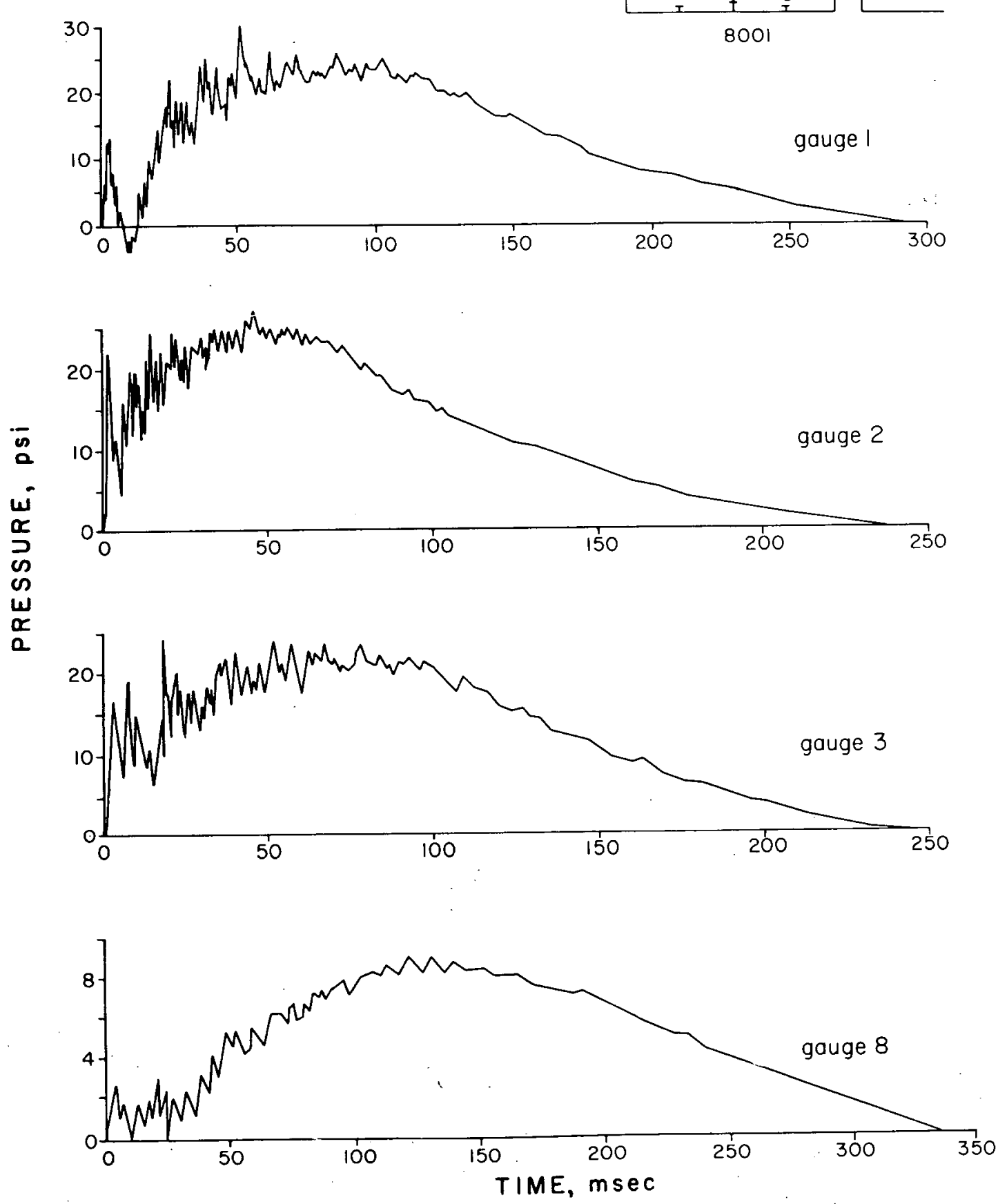

Fig. 3.4-Pressure-time curves as recorded inside shelter 8001 . 

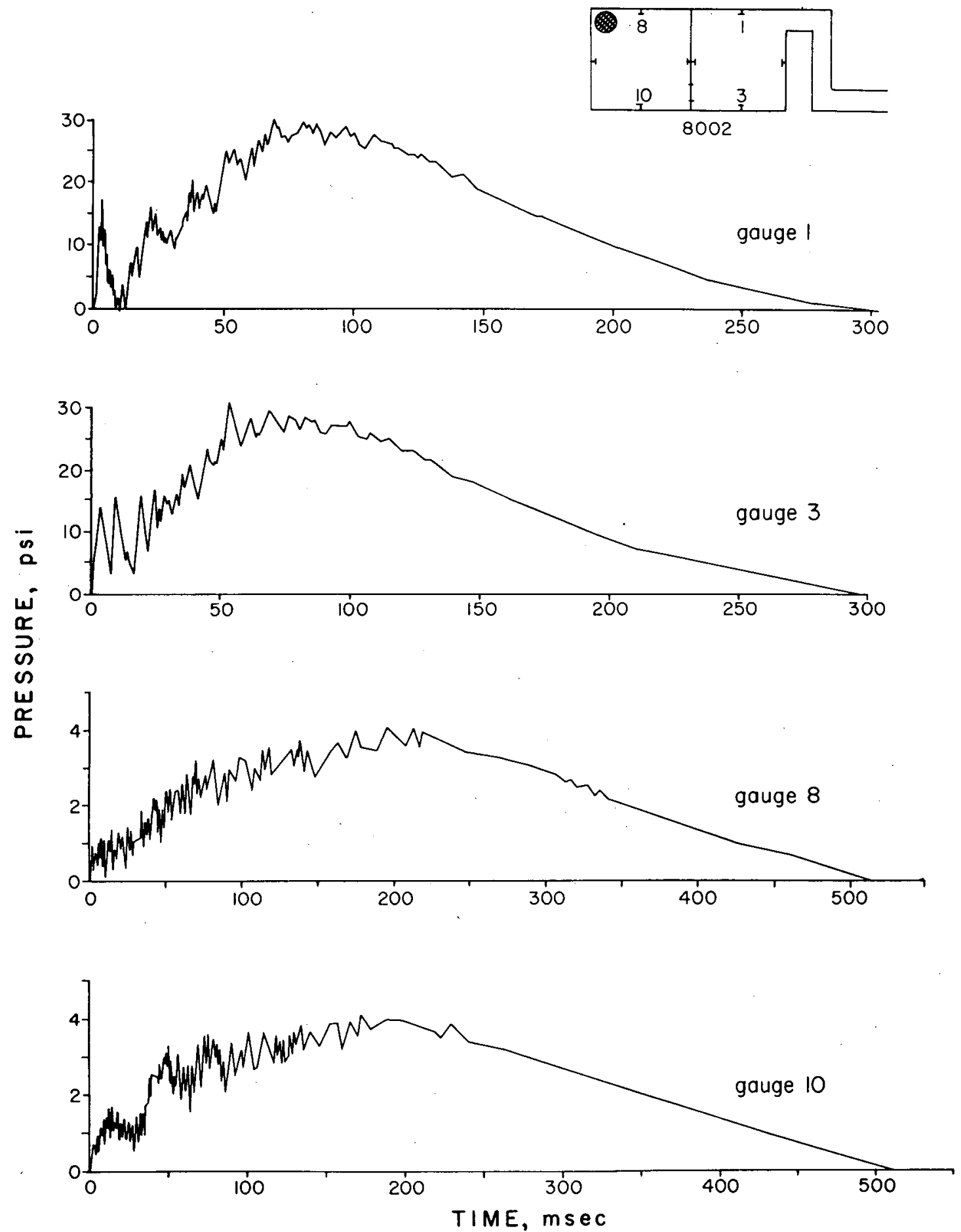

Fig. 3.5-Pressure-time curves as recorded inside shelter 8002 . 


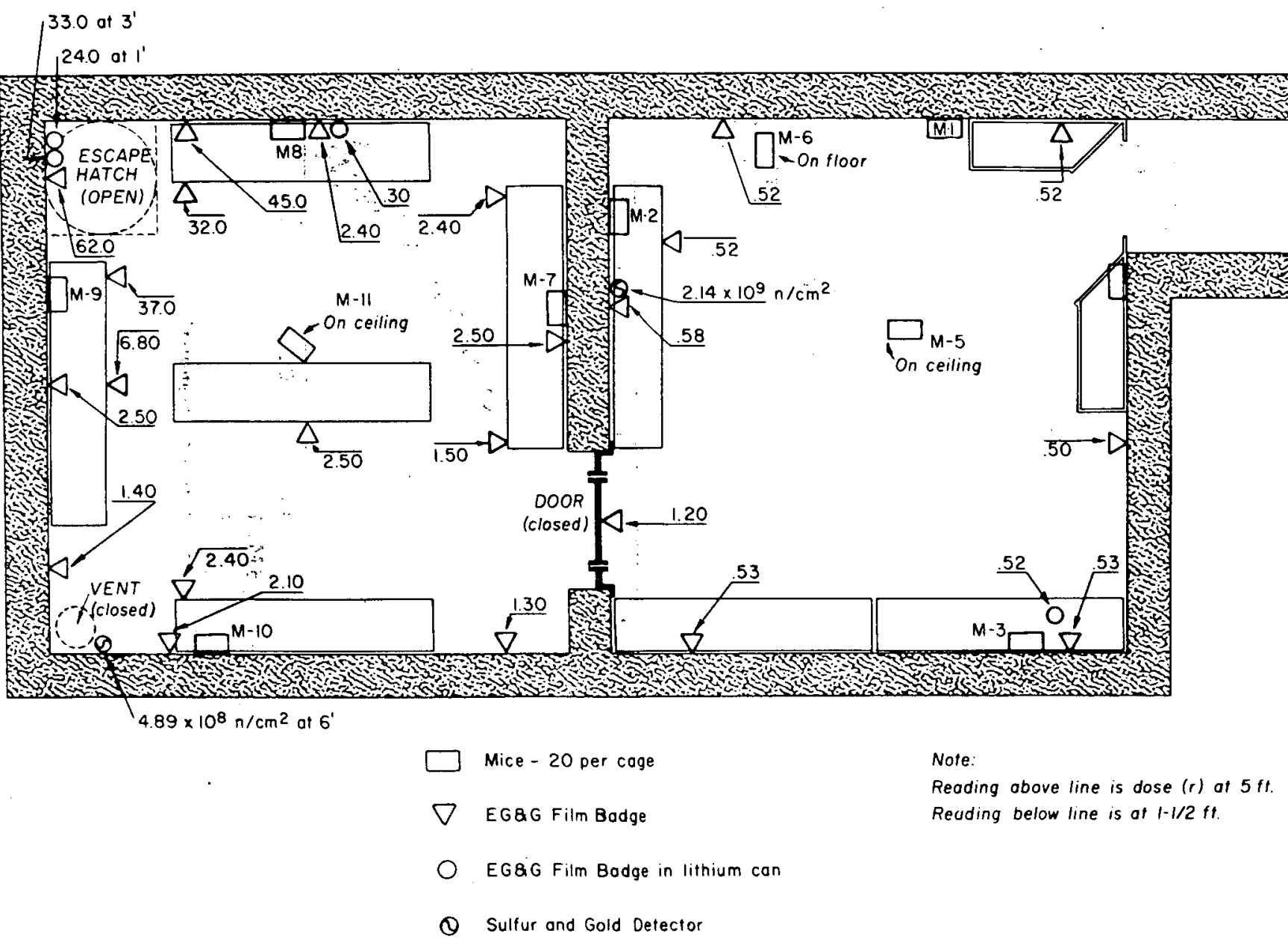

Fig. 3.6 - Locations and types of measurements recorded by the various radiation dosimeters within shelter 8001 . 


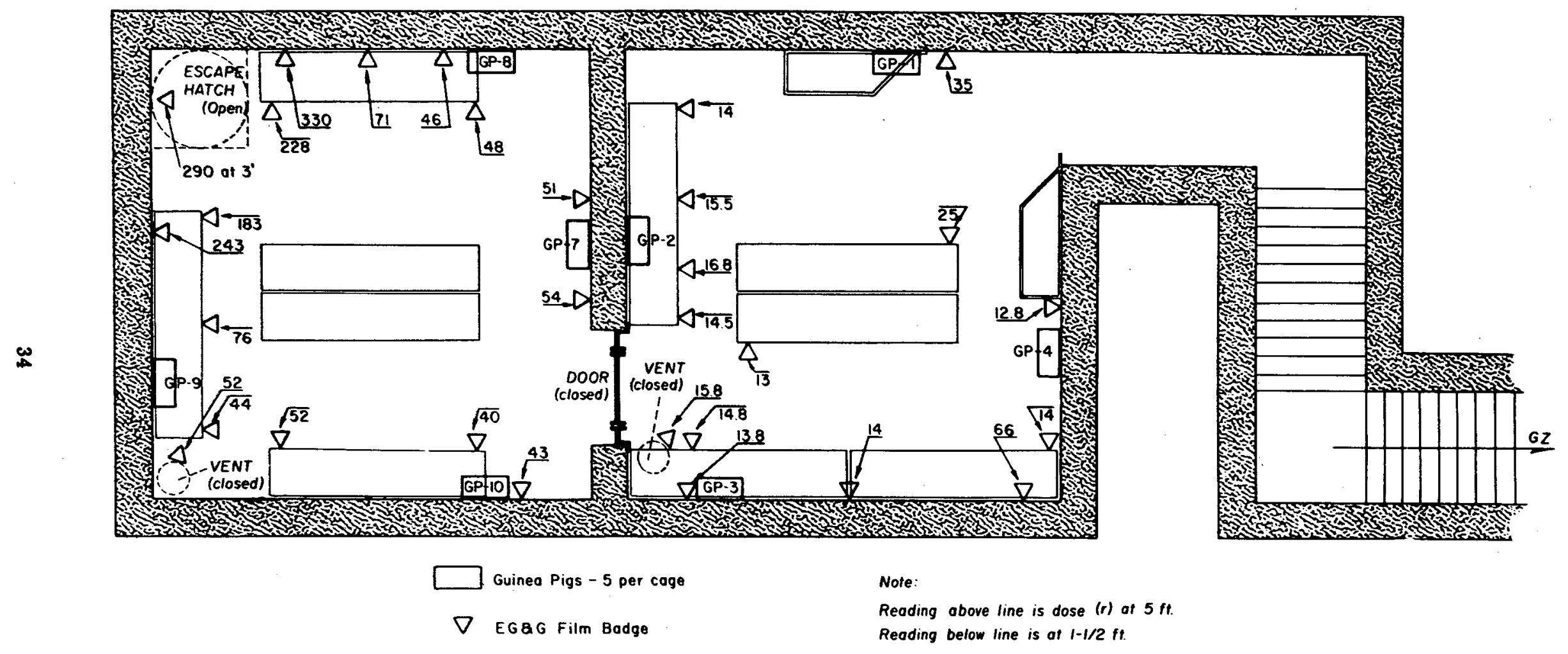

Fig. 3.7-Locations and types of measurements recorded by the various radiation dosimeters within shelter 8002 . 


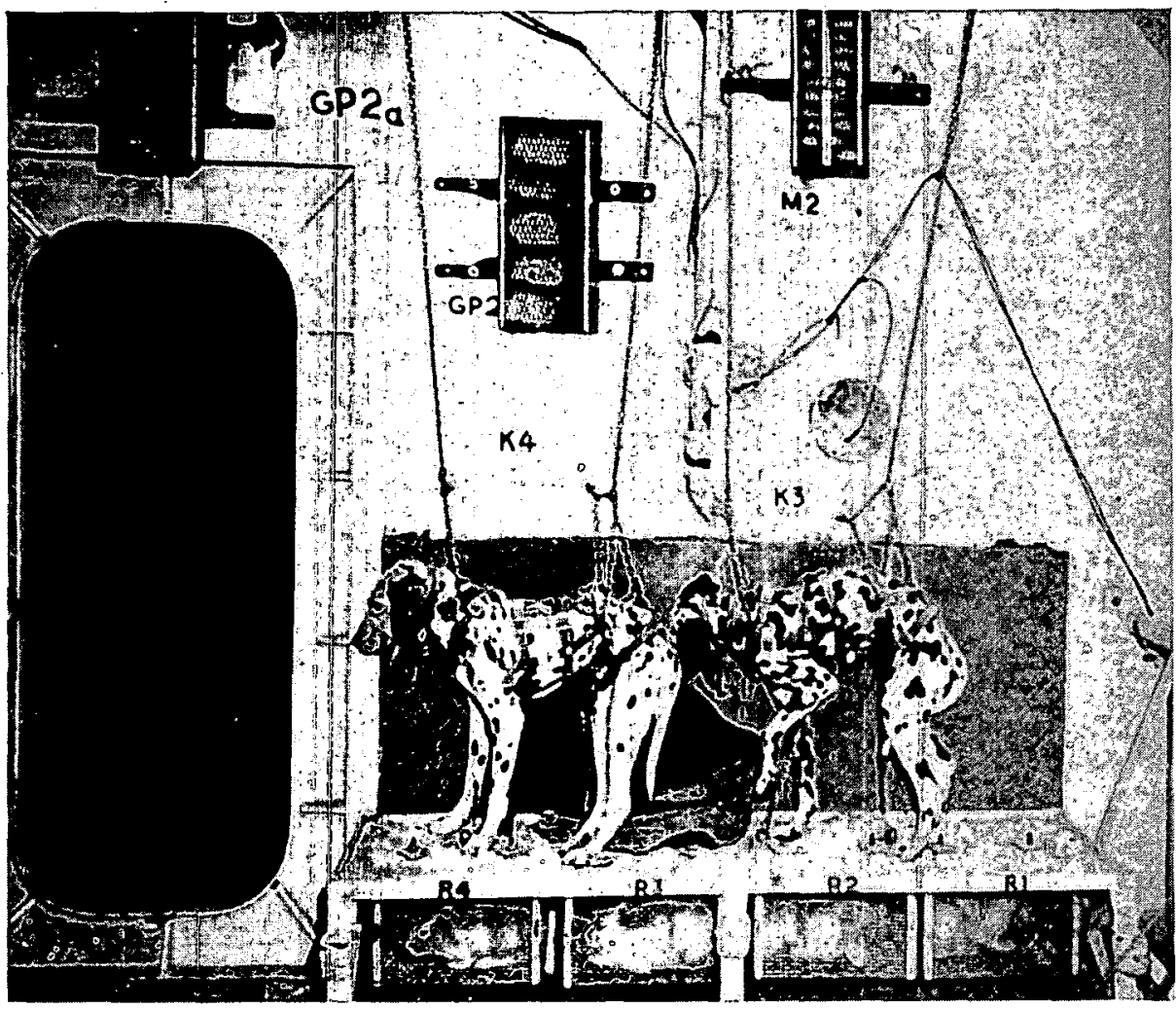

Fig. 3.8-Wall 2 of shelter 8001 to show point of impact for dog K-1.

(b) Post-mortem Findings. Blast injuries and thermal effects sustained by animals in shelter 8002 are summarized in Table 3.3 (the detailed tables are given in Appendix B). Aside from eardrum rupture and a few petechial hemorrhages found histologically in dog G-4, no dogs in either chamber received blast injuries. Rabbits 8 and 10 sustained slight pulmonary hemorrhages, and all but one guinea pig (3-2) of the samples of three autopsied from cages 2 , 3 , and 4 had slight lung hemorrhage. In addition to the 15 dead mice, 11 others from cages 1 , 2 , and 4 displayed this lesion. The swine near the entrance displayed different degrees of lung hemorrhages: No. 7, located in the ramp and killed by the blast, exhibited massive pulmonary hemorrhage; and Nos. 5 and 3 had moderate and slight degrees, respectively. Photographs of the excised lungs for Nos. 7 and 5 are illustrated in Fig. 3.10.

None of the animals in the slow-fill chamber exposed to an overpressure of only $4.1 \mathrm{psi}$ showed any primary blast-induced lesions other than eardrum rupture.

(c) Ionizing-radiation Effects. The measurements taken by the film badges at different locations inside shelter 8002 are illustrated in Fig. 3.7. Also included in the figure are the positions of the guinea pig cages since they. were the most radiosensitive animal species as far as mortality was concerned. It can be seen that the highest readings were just below the escape hatch. At distances greater than $6 \mathrm{ft}$ from beneath the hatch, the gamma radiation levels were between 40 and $76 \mathrm{r}$, which were about twice those measured in the fast-fill side of the structure. There were 14 rabbits, 16 guinea pigs, 2 swine, and 60 mice saved for possible radiation effects following shot 2 .

(1) Rabbits. With the exception of No. 1, all the odd numbered rabbits were held for observation. There was one acute radiation death, No. 11 , which died on $D+8$. The other 13 were sacrificed on $\mathrm{D}+\mathbf{5 5}$ and showed no remarkable pathology upon post-mortem examination.

(2) Mice. A chronic infection of Salmonella in the mouse colony masked any possible assessment of the effects of radiation, especially of the intermediate or terminal type. As can be seen in Fig. 3.11, the mortality rate among control animals was essentially as high as that for exposed animals. 


\begin{tabular}{|c|c|c|c|c|}
\hline Species & $\begin{array}{l}\text { Number of } \\
\text { animals } \\
\text { autopsied* }\end{array}$ & $\begin{array}{l}\text { Peak } \\
\text { pressure, } \\
\text { psi }\end{array}$ & $\begin{array}{l}\text { Duration of } \\
\text { overpressure, } \\
\text { msec }\end{array}$ & Pathological remarks \\
\hline \multicolumn{5}{|l|}{ Fast-fill } \\
\hline \multirow[t]{4}{*}{ Dog } & \multirow[t]{4}{*}{8} & 25.7 & 292 & \multirow{4}{*}{$\begin{array}{l}\text { No canine mortality; } \mathrm{K}-1 \text { severely injured from } \\
\text { impact, see text for details; } \mathrm{K}-1, \mathrm{~K}-3 \text {, and } \mathrm{K}-9 \\
\text { had petechial hemorrhages in lungs; } 8 / 16 \text { read- } \\
\text { able eardrums ruptured ( } 50 \% \text { ) }\end{array}$} \\
\hline & & 27.0 & 240 & \\
\hline & & 23.8 & 245 & \\
\hline & & 25.6 & 297 & \\
\hline Average & & 25.5 & 269 & \\
\hline Rabbit & 20 & & & $\begin{array}{l}\text { No mortality; } 5 \text { with slight lung hemorrhages (Nos. } \\
1,2,13,14 \text {, and } 15) ; 39 / 40 \text { eardrums ruptured } \\
(97.5 \%)\end{array}$ \\
\hline Guinea pig & 35 & & & $\begin{array}{l}\text { Two killed: } 3-1 \text { and } 6-3 ; 5 \text { others with lung hemor- } \\
\text { rhage (Nos. } 2 a-5 \text {, moderate; } 2-2,2-3,3-3 \text {, and } \\
3-4 \text {, slight); 52/52 eardrums ruptured }(100 \%)\end{array}$ \\
\hline Mouse & 60 & & & $\begin{array}{l}\text { Mortality: } 1 \text { from cage } 1 \text { and } 2 \text { from cage } 2 ; 16 \\
\text { cases of lung hemorrhage (10 from cage } 2,2 \\
\text { from cage } 4 \text {, and } 4 \text { from cage } 5 \text { ); ears not } \\
\text { assessed }\end{array}$ \\
\hline \multicolumn{5}{|l|}{ Slow-fill } \\
\hline Dog & 4 & $\begin{array}{r}9.0 \\
10.0\end{array}$ & 330 & $\begin{array}{l}\text { No significant pathology; } 0 / 10 \text { eardrums ruptured } \\
(0 \%)\end{array}$ \\
\hline Average & & 9.5 & & \\
\hline Guinea pig & 25 & & & $\begin{array}{l}\text { One slight lung hemorrhage (No. 11-4); } 38 / 44 \text { ear- } \\
\text { drums ruptured }(86.4 \%)\end{array}$ \\
\hline Mouse & 50 & & & No pathology; ears not examined \\
\hline
\end{tabular}

*In addition, 110 mice (10 from each cage) and 1 dog from each chamber (K-8 and $\mathrm{K}-14)$ were observed for possible radiation effects for 30 days postshot.

(3) Guinea Pigs. Two guinea pigs (Nos. 4 and 5) from each of the 8 cages, 4 each located in the fast-fill and slow-fill chambers, were saved for radiation study. All 16 died by the $73 d$ day following exposure. Their mortality is plotted in Fig. 3.12. Since the animals from both chambers died at about the same rate, the curve represents all 16 cases. From the figure it can be seen that 50 per cent were dead in 22 days and 62.5 per cent in 30 days. The initial body weights of the animals averaged $449 \mathrm{~g}$. On $\mathrm{D}+13$ their mean body weight was $382 \mathrm{~g}$, and at death it was $264 \mathrm{~g}$.

The more frequent pathological lesions recorded at autopsy are tabulated in Table 3.4, along with the time of death and the gamma dose (roentgens) taken from the film badge nearest the animal as reported by CETG Project 39.1 (see Fig. 3.7). The hemorrhagic nature of the lesions reported in the table, the rapid weight loss, and the time to death are consistent with the general pattern of radiation sickness.

Of the two swine saved by CETG Project 39.3, animal 9, located directly below the escape hatch, died of radiation sickness on $D+13$.

(d) Thermal Effects. In contrast to shot 1, the animals within the fast-fill room of shelter 8002 exhibited thermal effects similar to those recorded in the previous tests. ${ }^{2}$ Dog G-1, swine 5 and 7 , and mice from cages 1 and 2 were burned. All guinea pigs from cages 1 and 2 were singed. No thermal effects were noted on rabbits. Dog G-1 sustained first-degree burns about his hindquarters, in the area of both axillae, and about the mouth. This animal was extensively singed. Animals that exhibited gross thermal effects are specified in Table 3.3 and in the tables of Appendix B.

- A detailed study concerning the thermal effects is the subject of a separate report by CETG Project 39.3 (WT-1502). 


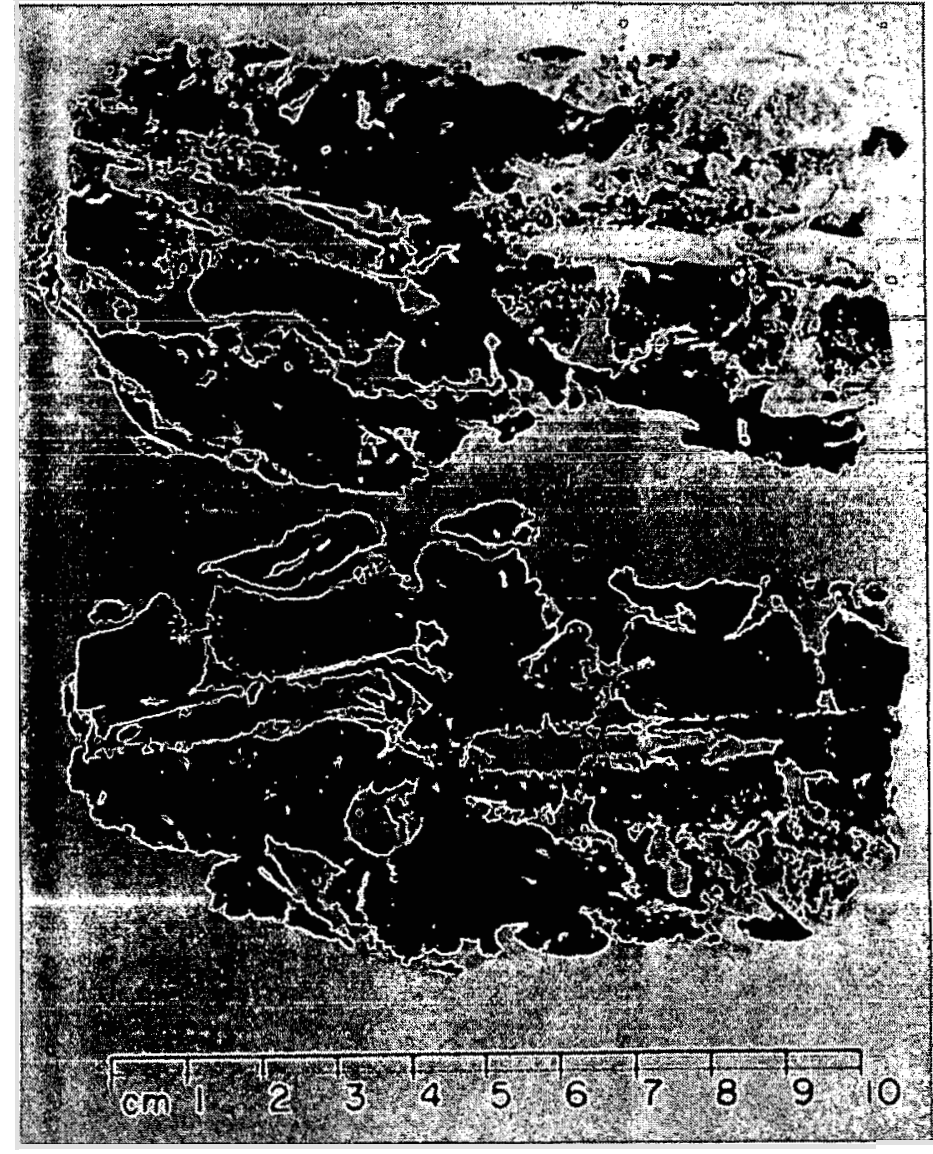

Fig. 3:9a-Fractured lumbar vertebra of dog $K-1$.

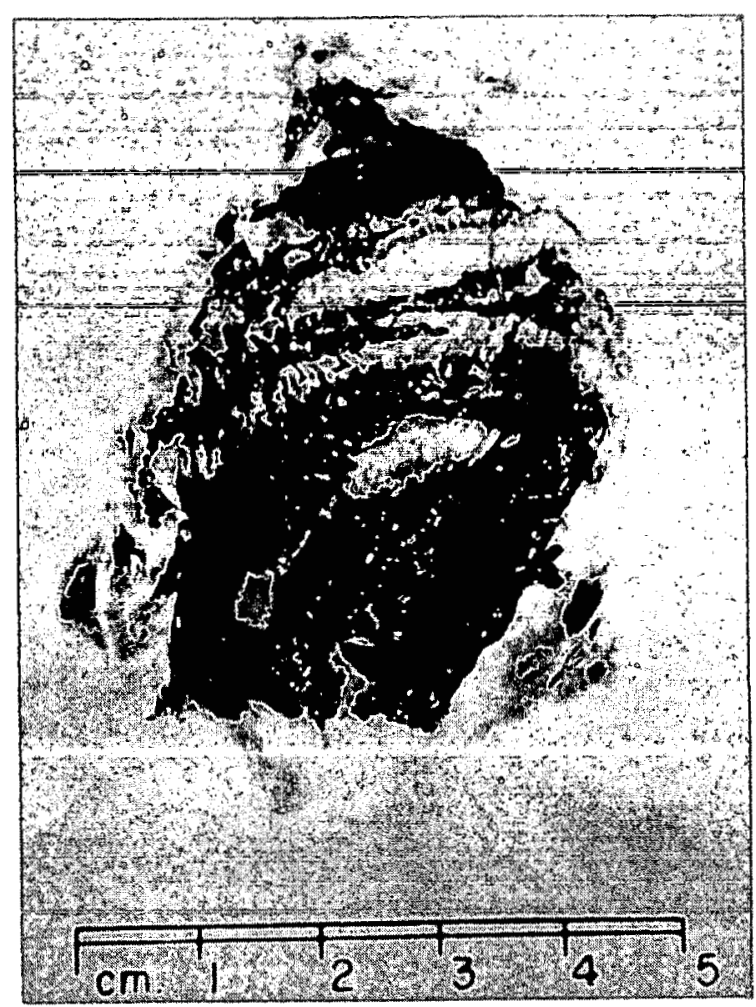

Fig. $3.9 \mathrm{~b}-$ Hemorrhaged lining of urinary bladder from dog $\mathrm{K}-1$. 

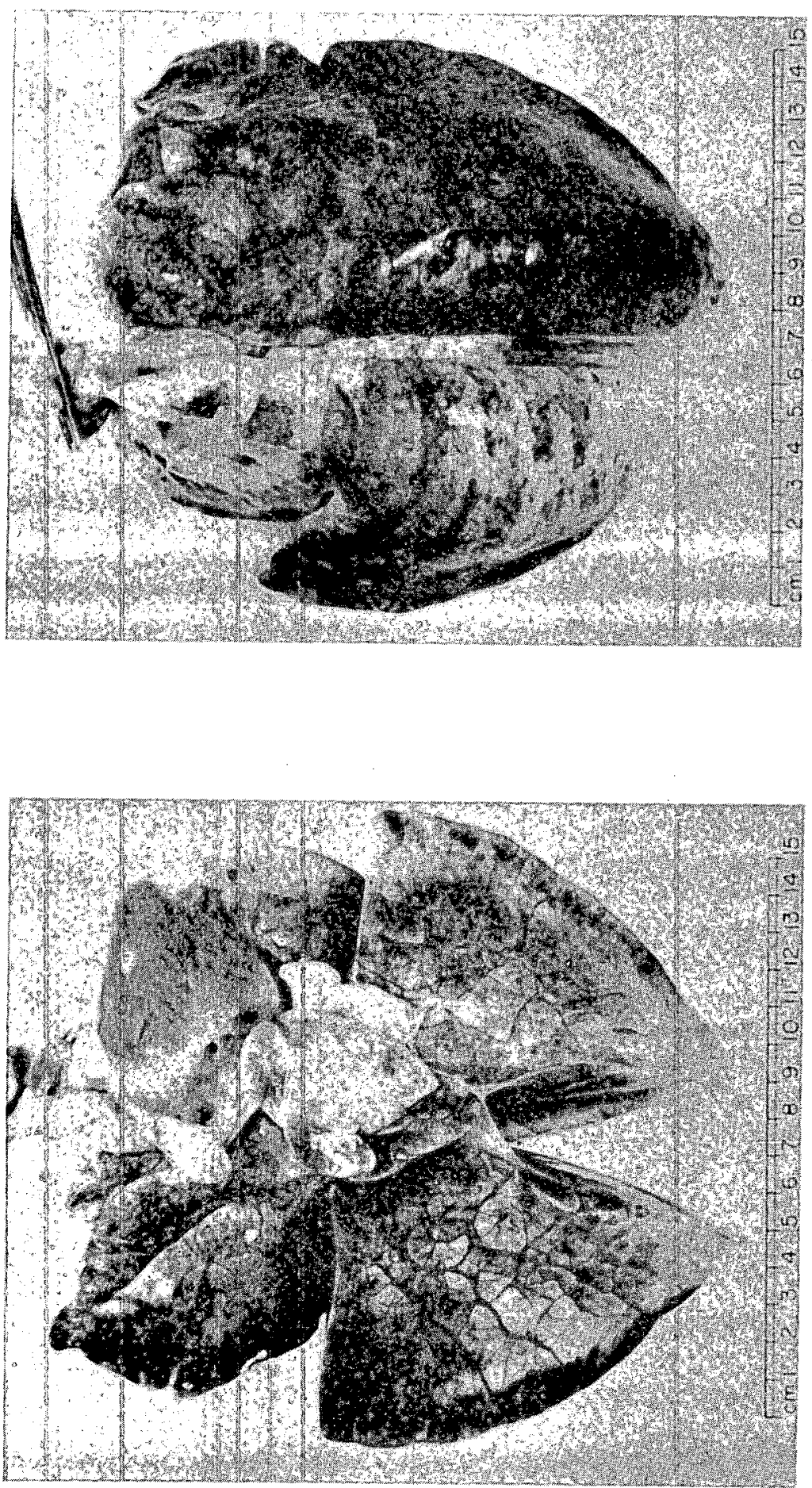

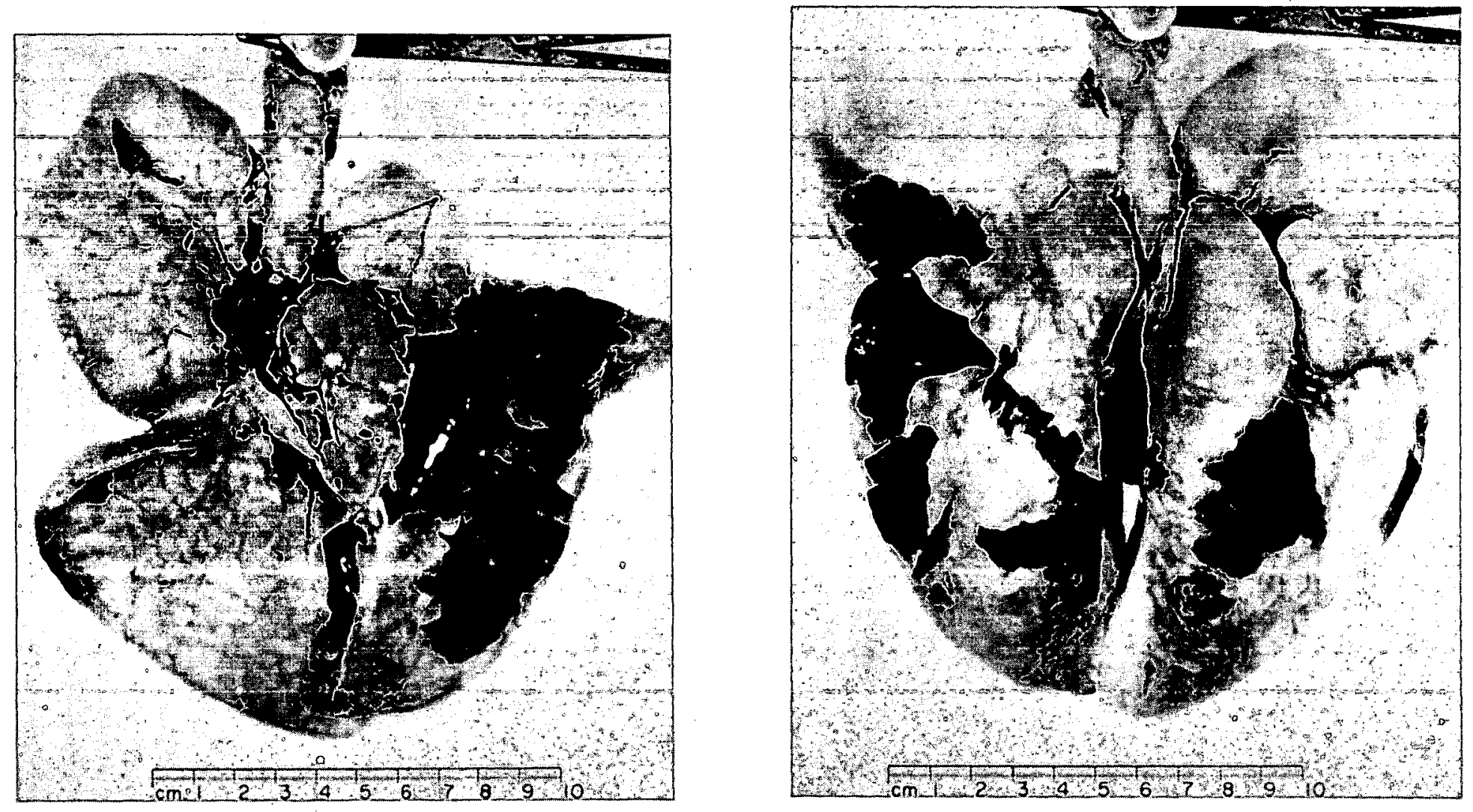

Fig. 3.10-Dorsal and ventral views of lungs from swine 5 (views on this page) and 7 (views on opposite page). 
TABLE 3.3-SUMMARY OF PATHOLOGICAL FINDINGS

\begin{tabular}{|c|c|c|c|c|}
\hline Species & $\begin{array}{l}\text { Number of } \\
\text { animals } \\
\text { autopsied } *\end{array}$ & $\begin{array}{l}\text { Peak } \\
\text { pressure, } \\
\text { psi }\end{array}$ & $\begin{array}{l}\text { Duration of } \\
\text { overpressure, } \\
\text { msec }\end{array}$ & Pathological remarks \\
\hline \multicolumn{5}{|l|}{ Fast-fill } \\
\hline Dog & 8 & $\begin{array}{l}30.4 \\
30.2 \\
30.5 \\
30.0\end{array}$ & $\begin{array}{l}305 \\
294\end{array}$ & $\begin{array}{l}\text { No mortality; G-1 burned and G-2 and G-5 singed } \\
\text { slightly; G-4 slight lung hemorrhage and nasal } \\
\text { sinus hemorrhaged; } 12 / 16 \text { eardrums ruptured } \\
(75 \%)\end{array}$ \\
\hline Average & & 30.3 & 300 & \\
\hline Rabbit & 6 & & & $\begin{array}{l}\text { No mortality; two slight lung hemorrhages (Nos. } 8 \\
\text { and } 10) ; 6 / 10 \text { eardrums ruptured }(60 \%)\end{array}$ \\
\hline $\begin{array}{l}\text { Guinea pig } \\
\end{array}$ & 12 & & & $\begin{array}{l}\text { No mortality; all animals in cages } 1 \text { and } 2 \text { were } \\
\text { singed; } 8 \text { animals exhibited lung hemorrhage ( } 3 \\
\text { from cages } 2 \text { and } 4,2 \text { from cage } 3) ; 24 / 24 \text { ear- } \\
\text { drums ruptured }(100 \%)\end{array}$ \\
\hline Mouse & 60 & & & $\begin{array}{l}\text { Mortality: } 14 \text { from cage } 1 \text { and } 1 \text { from cage } 2 \text {; the } \\
15 \text { dead mice had lung hemorrhage, also } 4 \text { of } \\
\text { cage } 1,6 \text { of cage } 2 \text {, and } 1 \text { of cage } 4 \text {; mice in } \\
\text { cages } 1 \text { and } 2 \text { were burned }\end{array}$ \\
\hline Pig & 5 & & & $\begin{array}{l}\text { Mortality: No. } 7 \text {; lung hemorrhage, No. } 7 \text {, massive; } \\
\text { No. } 5 \text {, moderate; No. } 3 \text {, slight; pigs } 5 \text { and } 7 \\
\text { burned; } 7 / 8 \text { eardrums ruptures }(87.5 \%)\end{array}$ \\
\hline \multicolumn{5}{|l|}{ Slow-fill } \\
\hline Dog & 2 & $\begin{array}{l}4.1 \\
4.1\end{array}$ & $\begin{array}{l}517 \\
506\end{array}$ & $\begin{array}{l}\text { No pathological lesions; } 1 / 4 \text { eardrums ruptured } \\
(25 \%)\end{array}$ \\
\hline Average & & 4.1 & 512 & \\
\hline Rabbit & 10 & & & No pathology except $2 / 19$ eardrums ruptured $(10.5 \%)$ \\
\hline Guinea pig & 12 & & & No pathology; $0 / 24$ eardrums ruptured $(0 \%)$ \\
\hline Mouse & 40 & & & No pathology; ears not examined \\
\hline
\end{tabular}

*There were 14 rabbits, 16 guinea pigs, 2 swine, and 60 mice saved for radiation effects. See Sec. 3.3.2(c) for the results.

(e) Dust. In shelter 8002 the concentration of dust appeared to be insignificant biologically. No animal died of dust suffocation nor was there any noticeable concentration in the upper respiratory passageways; neither were any particulates noted microscopically in the alveolar sections.

\subsection{PATHOLOGICAL EFFECTS AS RELATED TO THE PRESSURE-TIME ENVIRONMENT}

\subsubsection{Mortality}

It has become increasingly evident that death from primary blast is not related to the peak overpressure alone, particularly when the wave form is of the type recorded inside structures, in contrast to the single fast-rising pressure pulse and shock wave of short duration as generated with a high explosive in the open field. Laboratory work in Albuquerque has confirmed the field results in that, unless the leading edge of the pressure wave had a shock or reflected shock of considerable magnitude, the likelihood of death from primary blast was minimized even though the pressure ${ }^{3}$ eventually rose much above 100 psi. Specifically the steep-fronted wave shapes associated with the reflected shock wave at the closed end of a shock tube need only be 30 to 40 psi in magnitude to kill 50 per cent of the mice, rats, guinea pigs, and rabbits exposed side-on against the reflecting surface. ${ }^{4}$ Figure 3.13 illustrates the mortality curves taken from reference 4. Slow-rising pressures that peaked at 130 to $170 \mathrm{psi}$ in 30 to $155 \mathrm{msec}$ 


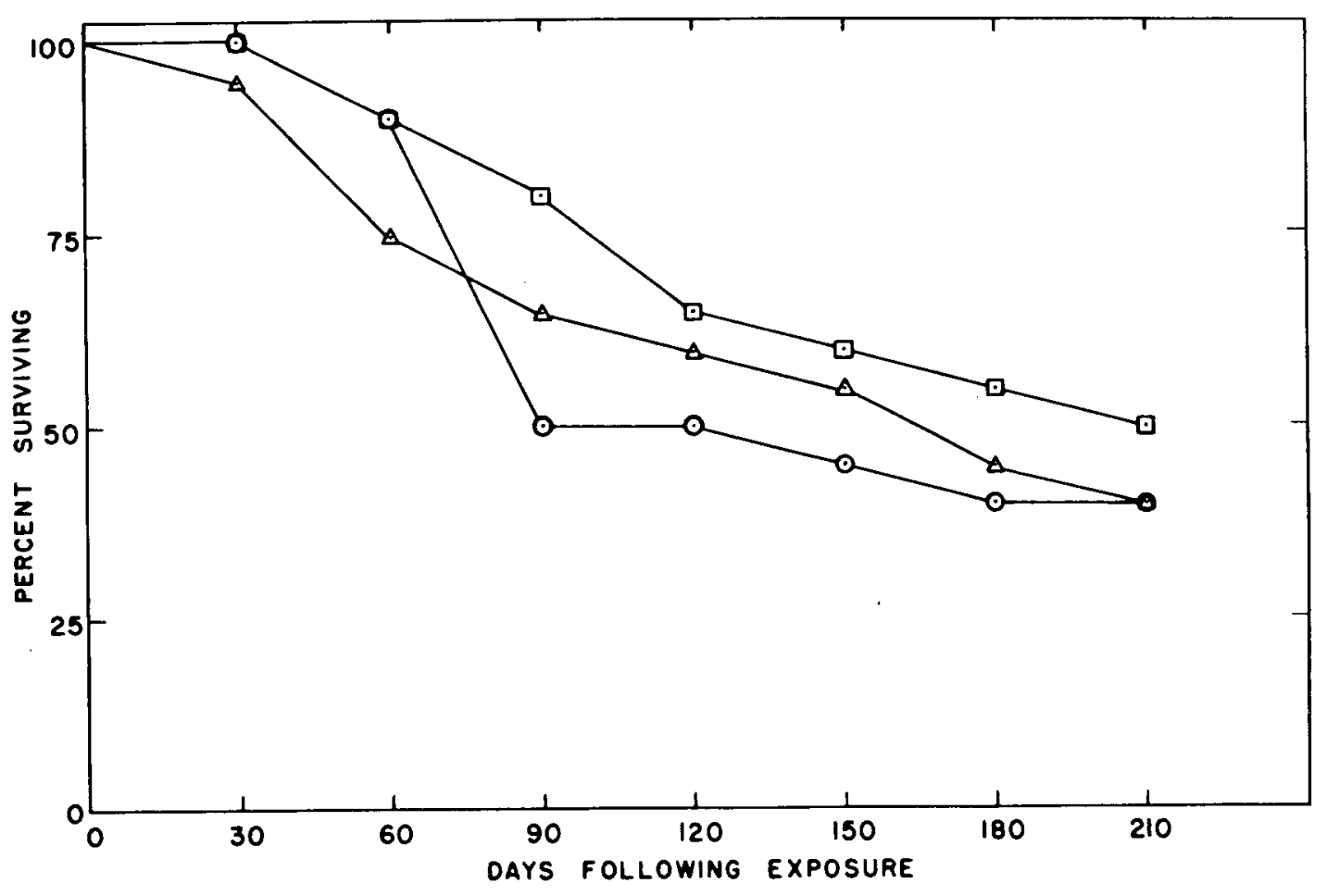

Fig. 3.11-Mortality curves for mice following exposure to radiation within shelter 8002. $\odot$, slow-fill; $\triangle$, fast-fill, and $\odot$, control.

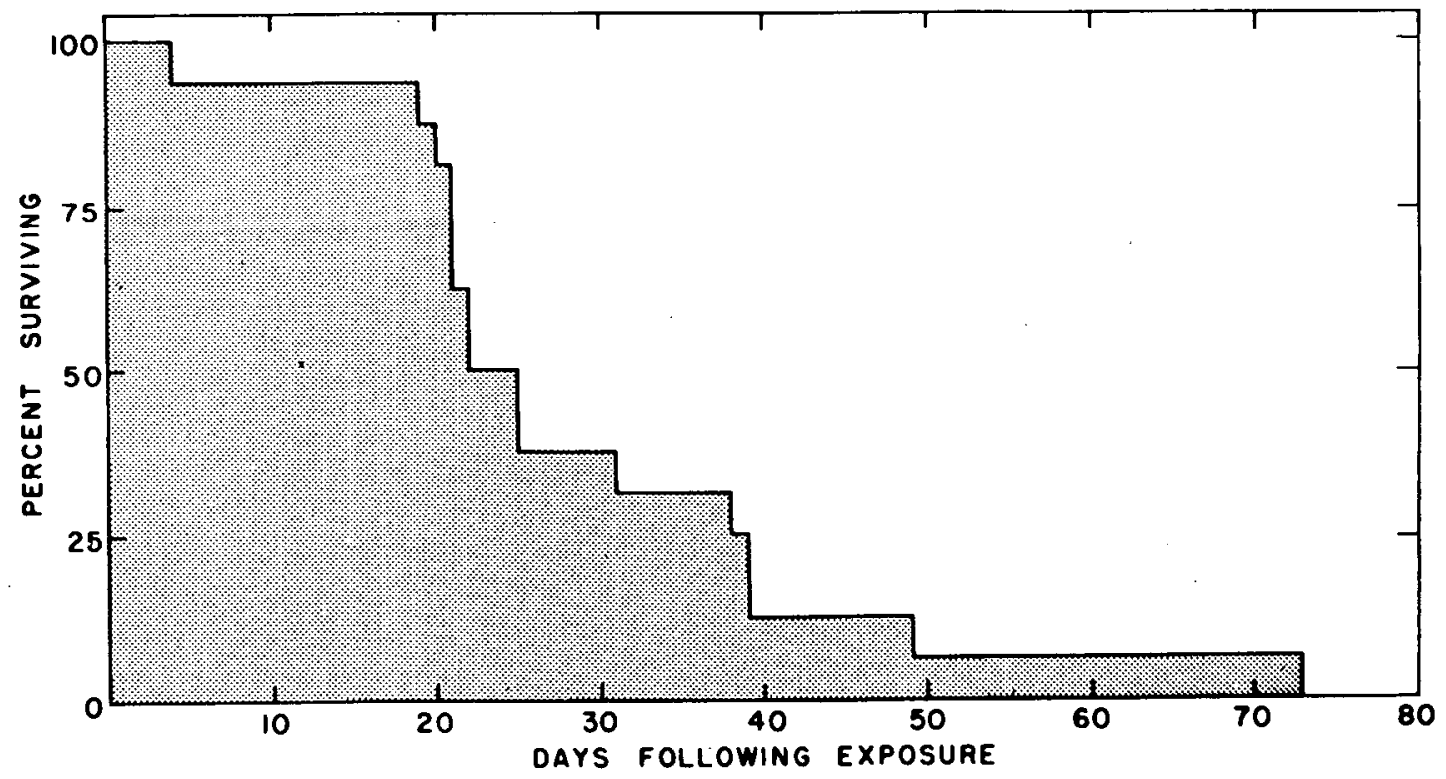

Fig. 3.12-Mortality curve for guinea pigs following exposure to radiation within shelter 8002 . 
TABLE 3.4-GROSS PATHOLOGICAL FINDINGS IN GUINEA PIGS EXPOSED TO RADIATION INSIDE SHELTER 8002

\begin{tabular}{|c|c|c|c|c|c|c|c|}
\hline \multirow[b]{2}{*}{$\begin{array}{c}\text { Animal } \\
\text { No. }\end{array}$} & \multirow[b]{2}{*}{$\begin{array}{c}\text { Gamma } \\
\text { dose, } r^{*}\end{array}$} & \multirow[b]{2}{*}{$\begin{array}{c}\text { Survival } \\
\text { time, } \\
\text { days }\end{array}$} & \multicolumn{5}{|c|}{ Pathology } \\
\hline & & & $\begin{array}{c}\text { Bloody } \\
\text { diarrhea } \\
\text { G-I tract }\end{array}$ & $\begin{array}{l}\text { Hemor- } \\
\text { rhages in } \\
\text { G-I tract }\end{array}$ & $\begin{array}{l}\text { Hemor- } \\
\text { rhagic } \\
\text { lungs }\end{array}$ & $\begin{array}{l}\text { Lymph } \\
\text { nodes } \\
\text { hem. }\end{array}$ & $\begin{array}{c}\text { Soft } \\
\text { tissue } \\
\text { hem. }\end{array}$ \\
\hline \multicolumn{8}{|l|}{ Fast-fill } \\
\hline $1-4$ & 35 & 21 & $\mathrm{x}$ & & $\mathrm{x}$ & & \\
\hline $1-5$ & & 25 & $\mathbf{x}$ & $\mathbf{x}$ & $\mathbf{x}$ & $x$ & $\mathrm{x}$ \\
\hline $2-4$ & 16.8 & 31 & $\mathbf{x}$ & & & & \\
\hline $2-5$ & & 38 & $\mathbf{x}$ & & & & \\
\hline $3-4$ & 13.8 & 4 & $\mathbf{x}$ & $x$ & $\mathbf{x}$ & & $x$ \\
\hline $3-5$ & & 25 & $\mathbf{x}$ & $\mathbf{x}$ & $\mathbf{x}$ & & \\
\hline $4-4$ & 12.8 & 39 & & & & & \\
\hline $4-5$ & & 49 & & & & & \\
\hline \multicolumn{8}{|l|}{ Slow-fill } \\
\hline $7-4$ & 54 & 19 & $\mathrm{x}$ & $\mathrm{x}$ & $x$ & $x$ & $\mathrm{x}$ \\
\hline $7-5$ & & 73 & & & & & \\
\hline $8-4$ & 48 & 21 & $x$ & $\mathbf{x}$ & $x$ & $\mathbf{x}$ & $\mathrm{x}$ \\
\hline $8-5$ & & 39 & & & $\mathrm{x}$ & & \\
\hline $9-4$ & 52 & 22 & $\mathbf{x}$ & $\mathbf{x}$ & $\mathrm{x}$ & & $\mathrm{x}$ \\
\hline $9-5$ & & 22 & $x$ & $\mathrm{x}$ & $x$ & & $x$ \\
\hline $10-4$ & 43 & 20 & $\mathrm{x}$ & $\mathbf{x}$ & & $\mathrm{x}$ & $\mathrm{x}$ \\
\hline $10-5$ & & 21 & $x$ & $\mathbf{x}$ & $x$ & $\mathbf{x}$ & \\
\hline
\end{tabular}

*Measurement taken from film badge closest to animal's cage, usually less than $2 \mathrm{ft}$.

were tolerated by dogs and small animals when shielded from the direct winds associated with the fllling of the test chamber. ${ }^{3}$ Information is needed on the critical rate of pressure rise which apparently is less than $10 \mathrm{msec}$.

In addition, the actual geometry at exposure was found to be very important. In particular, animals exposed side-on at short distances $(3,6$, and 12 in.) from the reflecting surface were not kdlled by the reflected shock pressure until it was half again that required to produce the $\mathrm{LD}_{50}$ against the reflecting surface. ${ }^{4}$ In Fig. 3.14 the mortality curves for guinea pigs exposed against, and 12 in. from, the end plate of a shock tube are given, along with the pressure-time profiles recorded at those points.

In view of the above laboratory findings, it is not surprising that few animals exposed in the present study were killed by primary blast effects at pressures of 30.3 psi and below, which peaked in $\mathbf{5 0} \mathrm{msec}$ or more. In fact, the only geometry in connection with a recorded pressurewave profile which would be suspected of having been damaging was that at wall 2 inside structure 8001. From Fig. 3.4 it can be seen that the pressure rose as "fast" as the gauge could follow to 22 psi - that known to be near the threshold for mortality in small animals as mentioned above, provided they are side-on against a reflecting surface. Faster responding pressure transducers of the piezoelectric type are required to define the initial portion of the pressure pulse - or any other fast transients that occur during blast-produced overpressures. Such gauges were not used in these tests.

In structure 8002 the mice and guinea pig cages were 8 in. from the walls, and, except for the mice in cage 1 , the only mortality was one mouse located on wall 2 . The mice in cage 1 were located so close to the door that the pressure to which they were exposed undoubtedly was much greater than that recorded by the gauges farther inside the shelter.

The other example of what may have been fatal primary blast conditions was swine 7 exposed in the entrance ramp side-on against the wall, a location unfortunately in which the pressure was not measured. It was estimated that reflected pressures ${ }^{5}$ may have reached 80 psi, which, in association with the geometry (side-on against the wall), no doubt should have been and probably was fatal. 


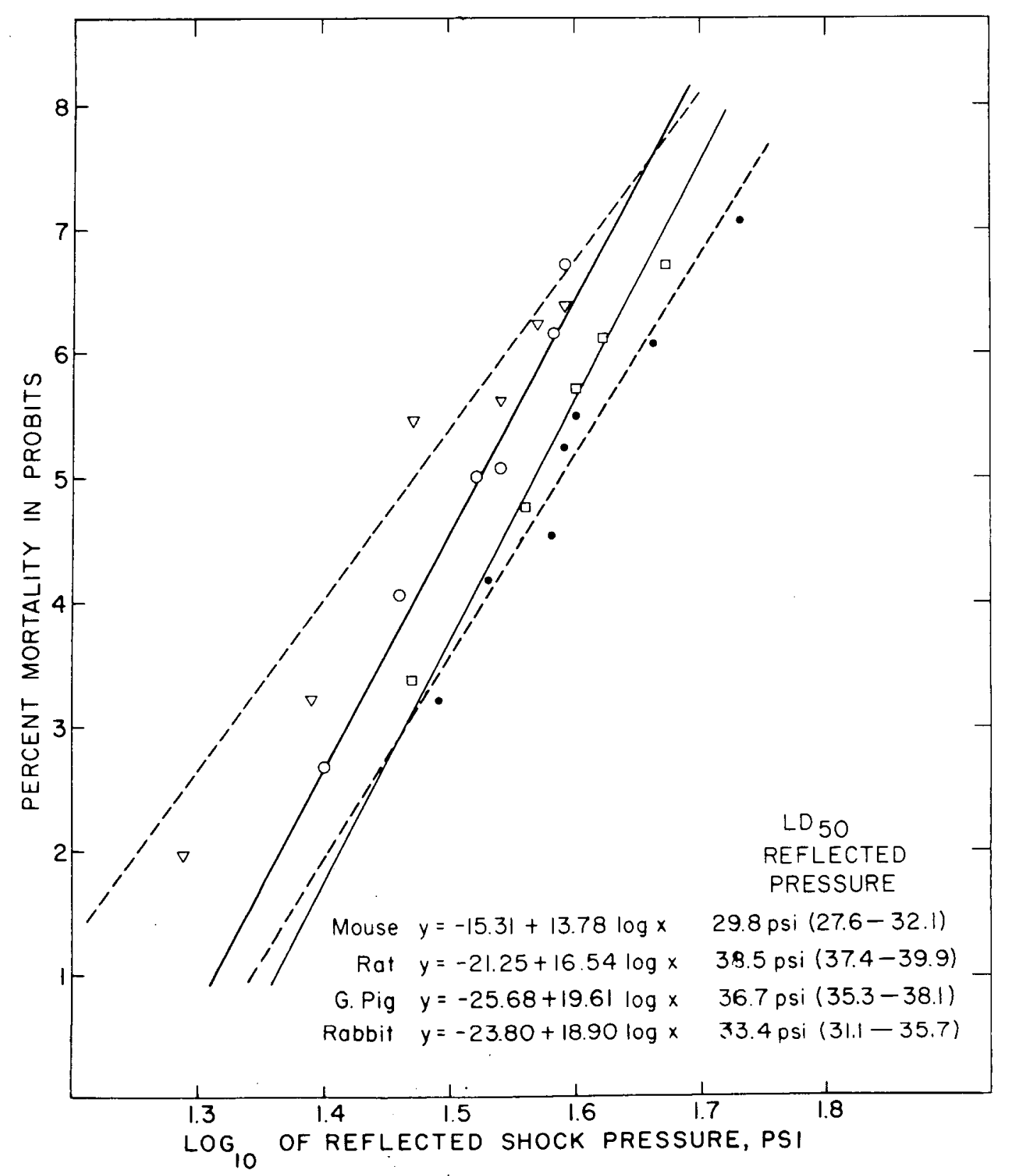

Fig. 3.13-Regression lines relating percentage mortality (probit unit) with the $\log$ of the pressure in the reflected shock. Included in the figure are the regression-line equations and the $\mathrm{LD}_{50}$ values with their 95 per cent confidence limits. $\nabla$, mouse. $\bullet$, rat. $\square$, guinea pig. $O$, rabbit.

\subsubsection{Pulmonary Hemor rhage}

In general, the extent of lung injury encountered in the present study was slight. Slight pulmonary hemorrhages were found in some of the small animals exposed within the fast-fill chambers where the magnitudes of the initial reflections were between 13 and $22 \mathrm{psi}$ and the pressure peaked at 25 to $30 \mathrm{psi}$.

That these conditions were not sufficient to produce anything more than threshold conditions for lung hemorrhage agreed with the laboratory findings of this group. That is, as former workers have found, the increase in lung weight of a blasted animal due to blood and edematous fluid present in the lung roughly correlates with the severity of the blast. ${ }^{6-8}$ Table 3.5 lists such an objective method of scoring lung damage compiled from the lung weights of over 500 


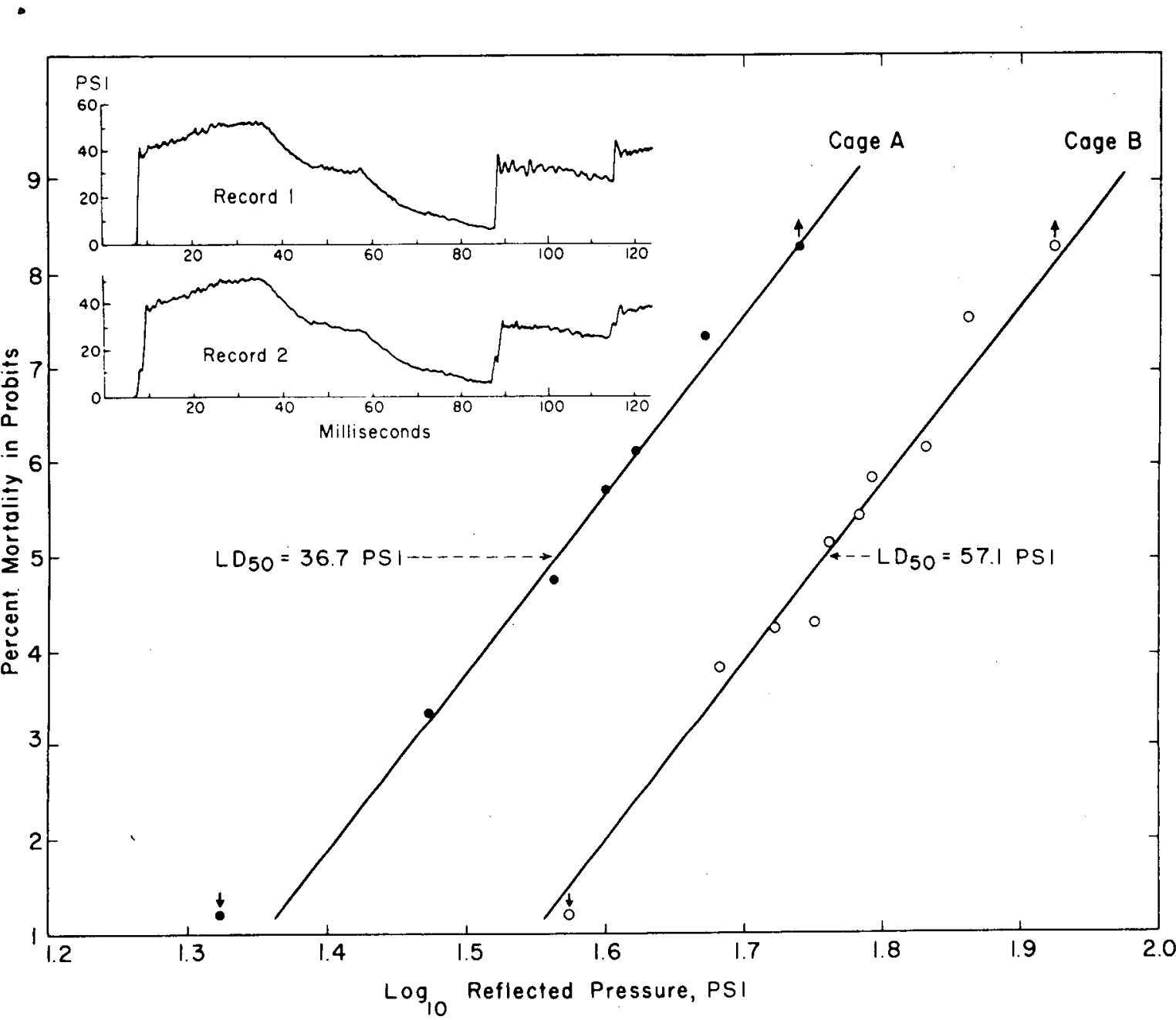

Fig. 3.14-Mortality curves for guinea pigs exposed against, and $12 \mathrm{in.} \mathrm{from,} \mathrm{the} \mathrm{closed} \mathrm{end} \mathrm{of} \mathrm{a} \mathrm{shock}$ tube.

guinea pigs involved in blast-tube mortality studies previously mentioned. According to the damage score for guinea pigs, little or no mortality would be expected with lung weights that are below 1.40 per cent of the animal's body weight.

The lung weight (expressed as per cent of the animal's body weight) averaged for the animals from each of the four pressure environmental groups encountered in the present study is tabulated in Table 3.6. The only groups that showed a slight but significant increase in lung

TABLE 3.5 - CRITERIA FOR LUNG BLAST INJURY ACCORDING TO LUNG WEIGHT: GUINEA PIG

\begin{tabular}{cccc}
\hline $\begin{array}{c}\text { Lung } \\
\text { damage } \\
\text { score }\end{array}$ & Lung weight, \% of body weight & $\begin{array}{c}\text { Mean and } \\
\text { SE of mean* }\end{array}$ & $\begin{array}{c}\text { Associated } \\
\text { mortality, } \\
\%\end{array}$ \\
\hline 0 & $<1.00$ & $0.91 \pm 0.01$ & 0 \\
I & $1.00-1.39$ & $1.17 \pm 0.01$ & 0 \\
II & $1.40-1.89$ & $1.67 \pm 0.02$ & 8.8 \\
III & $1.90-2.45$ & $2.20 \pm 0.01$ & 55.3 \\
IV & $>2.45$ & $2.88 \pm 0.02$ & 80.6 \\
\hline
\end{tabular}

*Standard error of the mean calculated by $\mathrm{SE}=$ $\sqrt{\epsilon \mathrm{d}^{2} / \mathrm{n}(\mathrm{n}-1)}$. 
TABLE 3.6-COMPARISON OF THE LUNG WEIGHTS FOR BLASTED ANIMALS TO THOSE OF THEIR CONTROLS

\begin{tabular}{|c|c|c|c|c|}
\hline $\begin{array}{c}\text { Group } \\
\text { (peak pressure) }\end{array}$ & $\mathrm{n}$ & Body weight* & $\begin{array}{l}\text { Lung weight, } \% \\
\text { of body weight }\end{array}$ & $\mathrm{P} \dagger$ \\
\hline \multicolumn{5}{|c|}{ Gulnea Plg } \\
\hline Control & 50 & $455 \pm 7 \mathrm{~g}$ & $0.89 \pm 0.02$ & \\
\hline $4.1 \mathrm{psi}(8002)$ & 12 & $452 \pm 8 \mathrm{~g}$ & $0.86 \pm 0.05$ & $>0.50$ \\
\hline $9.5 \mathrm{psi}(8001)$ & 25 & $469 \pm 16 \mathrm{~g}$ & $1.10 \pm 0.08$ & $<0.02->0.01$ \\
\hline $25.5 \mathrm{psi}(8001)$ & 35 & $453 \pm 13 \mathrm{~g}$ & $1.11 \pm 0.07$ & $<0.01 \rightarrow 0.001$ \\
\hline 30.3 psi $(8002)$ & 12 & $447 \pm 15 \mathrm{~g}$ & $1.07 \pm 0.15$ & $>0.20$ \\
\hline \multicolumn{5}{|c|}{ Rabbit } \\
\hline Control & 13 & $2115 \pm 68 \mathrm{~g}$ & $0.57 \pm 0.04$ & \\
\hline $4.1 \mathrm{psi}(8002)$ & 10 & $2652 \pm 132 \mathrm{~g}$ & $0.47 \pm 0.04$ & $<0.10->0.05$ \\
\hline 25.5 psi $(8001)$ & 20 & $2354 \pm 94 \mathrm{~g}$ & $0.49 \pm 0.02$ & $<0.10 \rightarrow>0.05$ \\
\hline 30.3 psi $(8002)$ & 6 & $2795 \pm 71 \mathrm{~g}$ & $0.48 \pm 0.04$ & $>0.10$ \\
\hline \multicolumn{5}{|c|}{ Dog } \\
\hline Control & 14 & $15.0 \pm 0.45 \mathrm{~kg}$ & $0.98 \pm 0.02$ & \\
\hline 4.1 psi $(8002)$ & 2 & $18.0 \pm 1.55 \mathrm{~kg}$ & $0.98 \pm 0.06$ & $>0.10$ \\
\hline $9.5 \mathrm{psi}(8001)$ & 4 & $15.4 \pm 0.7 \mathrm{~kg}$ & $1.10 \pm 0.03$ & $<0.01$ \\
\hline 25.5 psi $(8001)$ & 4 & $16.8 \pm 0.6 \mathrm{~kg}$ & $1.01 \pm 0.07$ & $>0.50$ \\
\hline 30.3 psi $(8002$ & 8 & $20.3 \pm 0.8 \mathrm{~kg}$ & $1.04 \pm 0.03$ & $>0.10$ \\
\hline
\end{tabular}

*Mean and standard error of the mean computed by $S E=\sqrt{\epsilon d^{2} / n(n-1)}$.

$\dagger$ Probability that the mean when compared to that for the controls differed by chance. P from Fisher's table of " $t$ " - the former calculated by

$$
t=M_{1}-M_{2} / \sqrt{S E_{1}^{2}+S E_{2}^{2}}
$$

weights were the guinea pigs from shelter 8001 exposed to peak overpressures of 9.5 and 25.5 psi and the group of four dogs exposed to $9.5 \mathrm{psi}$ in the same structure. No doubt the high incidence of pneumonia among the guinea pigs prior to shot 1 increased their lung weights; however, as can be seen in Table 3.5, the weights would still only correspond to a damage score of between 0 and 1 or between none and slight lung hemorrhage. In regard to the dog group exposed to $9.5 \mathrm{psi}$, the reason for the slightly heavier lungs is not known, but it may well have been fortuitous.

\subsubsection{Tympanic Membrane Rupture}

The relation between eardrum rupture and the average peak overpressures recorded within each of the four chambers involved in the present tests is summarized in Table 3.7. Until more information becomes available, it seems reasonable to assume, as in the past, that, for the pressure-time characteristics associated with a nuclear blast wave inside a structure, eardrum rupture is associated with the peak overpressure. ${ }^{2}$ The eardrum data gathered for 241 guinea pigs, 137 rabbits, and 219 dogs exposed inside shelters in the past three continental operations, Upshot-Knothole, ${ }^{9}$ Teapot, ${ }^{2}$ and Plumbbob, are tabulated in Table 3.8 for guinea pigs and rabbițs and in Table 3.9 for dogs. The most complete data are available for dogs, and, since an arithmetic plot suggested a sigmoid curve, the probit transformation of Finney was applied to data from each group. ${ }^{10}$ The regression line, its equation, and the $\mathrm{LD}_{50}$ value (the pressure required to rupture $\mathbf{5 0}$ per cent of the eardrums) so calculated are illustrated in Figs. 3.15 to 3.17 for guinea pigs, rabbits, and dogs, respectively. The pressures required to rupture 50 per cent of the eardrums of guinea pigs, rabbits, and dogs were found to be 7.4, 9.3, and 31.2 psi.

The eardrum data for rabbits compare favorably with those of Clemedson. He found reddening of rabbit eardrums at 0.5 atm and rupture below $1 \mathrm{~atm}$ of blast pressure. ${ }^{7}$ No values of the tolerance of canine eardrum to blast-produced pressures are available. A value for 10 
TABLE 3.7-TABULATION OF TYMPANIC MEMBRANE RUPTURE AS RELATED TO PEAK PRESSURE INSIDE SHELTERS

\begin{tabular}{cllll}
\hline $\begin{array}{c}\text { Maximum } \\
\text { overpressure, } \\
\text { psi }\end{array}$ & \multicolumn{1}{c}{ Dog } & \multicolumn{1}{c}{ Rupture, $\%$} \\
\hline $4.1(8002)$ & $25.0(1 / 4) *$ & $10.5(2 / 19)$ & $0(0 / 40)$ & $0(0 / 6)$ \\
$9.5(8001)$ & $0(0 / 10)$ & & $86.4(38 / 44)$ & \\
$25.5(8001)$ & $50.0(8 / 16)$ & $97.5(39 / 40)$ & $100(52 / 52)$ & \\
$30.3(8002)$ & $75.0(12 / 16)$ & $60.0(6 / 10)$ & $100(38 / 38)$ & $87.5(7 / 8)$ \\
\hline
\end{tabular}

* Figures in parentheses are the number ruptured over the number examined.

TABLE 3.8-GUINEA PIG AND RABBIT EARDRUM RUPTURE AS RELATED TO PEAK OVERPRESSURE INSIDE SHELTERS

\begin{tabular}{|c|c|c|}
\hline \multirow{2}{*}{$\begin{array}{l}\text { Maximum } \\
\text { overpressure, } \\
\text { psi }\end{array}$} & \multicolumn{2}{|c|}{ Rupture,*\% } \\
\hline & Guinea pig & Rabbit \\
\hline 4.1 & $0(0 / 40)$ & $6.4(2 / 31)$ \\
\hline $6.7 \dagger$ & $46(13 / 28)$ & $45.8(11 / 24)$ \\
\hline 9.5 & $86(38 / 44)$ & \\
\hline $22.0 \dagger$ & $91(29 / 32)$ & $72.0(18 / 25)$ \\
\hline 25.5 & $100(52 / 52)$ & $97.5(39 / 40)$ \\
\hline 30.3 & $100(38 / 38)$ & $60.0(6 / 10)$ \\
\hline $53.0 \dagger$ & $100(2 / 2)$ & $50.0(1 / 2)$ \\
\hline $66.6 \dagger$ & $100(5 / 5)$ & $80.0(4 / 5)$ \\
\hline
\end{tabular}

* Figures in parentheses are the number ruptured over the total number assessed.

†Data from Operation Teapot ${ }^{2}$ (Plumbbob data undesignated).

dogs of 14.9 psi (range 8 to $22.8 \mathrm{psi}$ ) was reported as a mean pressure required for drum rupture when the pressure was applied statically. ${ }^{11}$ It is not known whether the two situations are comparable.

\subsubsection{Tertiary Blast Effects}

Dog K-1, exposed to a maximum $Q$ of 10.5 psi, attained sufficient velocity to sustain serious injury upon impact with the shelter wall. The internal injuries mentioned previously were not unlike those reported for related forms of traumatic experiences (falls, automobile accidents, plane crashes, etc.). ${ }^{12-14}$ In contrast, a dog (G-1) loaded with a dynamic pressure of 2 psi experienced no tertiary effects. No other animals were displaced, indicating this hazard decreases rapidly at increasing distances from the door.

\subsection{PROTECTIVE BAFFLES}

The solid baffle performed satisfactorily at a $Q$ of $10.5 \mathrm{psi}$; the animal located behind it showed no evidence of wind loading or displacement as evidenced by the lack of broken string tethers. In contrast, several strings were broken on animal G-2, located behind the screen baffle at a $Q$ of only 2 psi.

Animals to the left of the door rigged for tertiary effects remained in place on both shots; this suggests that the location did not receive significant dynamic pressure, although in Operation Teapot a dog in about the same location was torn from his harness and sustained a fractured left femur. ${ }^{2}$ 
TABLE 3.9-DOG EARDRUM RUPTURE AS RELATED

TO PEAK OVERPRESSURE INSIDE SHELTERS

\begin{tabular}{|c|c|c|c|c|c|c|c|}
\hline Group & Operation* & $\begin{array}{r}\mathbf{M} \\
\text { over }\end{array}$ & $\begin{array}{l}\text { aximum } \\
\text { pressure, } \\
\text { psi }\end{array}$ & & $\begin{array}{l}\text { Number } \\
\text { ruptured/ } \\
\text { total }\end{array}$ & Rup & pture, $\%$ \\
\hline \multirow[t]{7}{*}{1} & Teapot & & 1.3 & & $0 / 4$ & & 0 \\
\hline & Teapot & & 2.6 & & $0 / 4$ & & 0 \\
\hline & Teapot & . & 3.7 & & $0 / 4$ & & 0 \\
\hline & Plumbbob & & 4.1 & & $1 / 4$ & & 25 \\
\hline & Teapot & & 4.3 & & $0 / 4$ & & 0 \\
\hline & Teapot & & 4.6 & & $1 / 4$ & & 25 \\
\hline & & Average & 3.4 & Total & $12 / 24$ & Average & 8.3 \\
\hline \multirow[t]{4}{*}{2} & Teapot & & 6.7 & & $0 / 20$ & & $0^{\prime}$ \\
\hline & Upshot-Knothole & & 9.0 & & $1 / 24$ & & 4.2 \\
\hline & Plumbbob & & 9.5 & & $0 / 10$ & & 0 \\
\hline & & Average & 8.4 & Total & $1 \quad 1 / 54$ & Average & 1.9 \\
\hline \multirow[t]{4}{*}{3} & Teapot & & 12.5 & & $0 / 4$ & & 0 \\
\hline & Upshot-Knothole & & 18.0 & & $1 / 16$ & & 6.3 \\
\hline & Teapot & & 18.5 & & $2 / 4$ & & 50.0 \\
\hline & & Average & 16.3 & Total & $13 / 24 A$ & Average & 12.5 \\
\hline \multirow[t]{4}{*}{4} & Teapot & & 22.0 & & $8 / 12$ & & 66.7 \\
\hline & Upshot-Knothole & & 22.5 & & $1 / 14$ & & 7.1 \\
\hline & Plumbbob & & 25.5 & & $8 / 16$ & & 25.5 \\
\hline & & Average & 23.3 & Total & $17 / 42 \quad A$ & Average & 40.5 \\
\hline \multirow[t]{3}{*}{5} & Plumbbob & & 30.3 & & $12 / 16$ & & 75.0 \\
\hline & Teapot & & 33.8 & & $10 / 20$ & & 50.0 \\
\hline & & Average & 32.1 & Total & $22 / 36$ & Average & 61.3 \\
\hline \multirow[t]{4}{*}{6} & Upshot-Knothole & & 38.0 & & $5 / 8$ & & 62.5 \\
\hline & Teapot & & 40.9 & & $2 / 4$ & & 50.0 \\
\hline & Teapot & & 42.8 & & $2 / 4$ & & 50.0 \\
\hline & & Average & 40.6 & Total & $9 / 16$ & Average & 56.3 \\
\hline 7 & Teapot & & 53.0 & & $3 / 4$ & & 75.0 \\
\hline 8 & Teapot & & 66.6 & & $10 / 12$ & & 83.0 \\
\hline 9 & Teapot & & 71.6 & & $3 / 3$ & & 100.0 \\
\hline 10 & Teapot & & 85.8 & & $4 / 4$ & & 100.0 \\
\hline
\end{tabular}

*Data for Operation Teapot and Operation Upshot-Knothole are from references 2 and 9, respectively.

\subsection{EVALUATION OF THE AERODYNAMIC MOUND}

\subsubsection{General}

As previously mentioned the mound had a 36 -in.-diameter circular inlet down to near grade, below which the shelter escape hatch was $3 \mathrm{ft}$ square. On shot 2 a sleve plate covered the orifice of the mound. The various physical parameters recorded within the slow-fill chamber are summarized in Table 3.1. The pressure-time record from gauge 8 inside structure 8001 and gauges 8 and 10 in structure 8002 are illustrated in Figs. 3.4 and 3.5. On both tests the incident pressure wave had approximately the same magnitude (42.1 and $39.2 \mathrm{psi})$ and duration but was quite different in protile. In particular, on shot 1 the blast wave was of the classical type, the pressure increased suddenly (within a few msec) to its maximum value and then fell to ambient (Fig. 3.18). In contrast, on shot 2 it was of the nonclassical type, commonly recorded in the field, in which the pressure increased in a stepwise manner, peaked in about 60 msec, and then decayed to ambient (Fig. 3.19). 


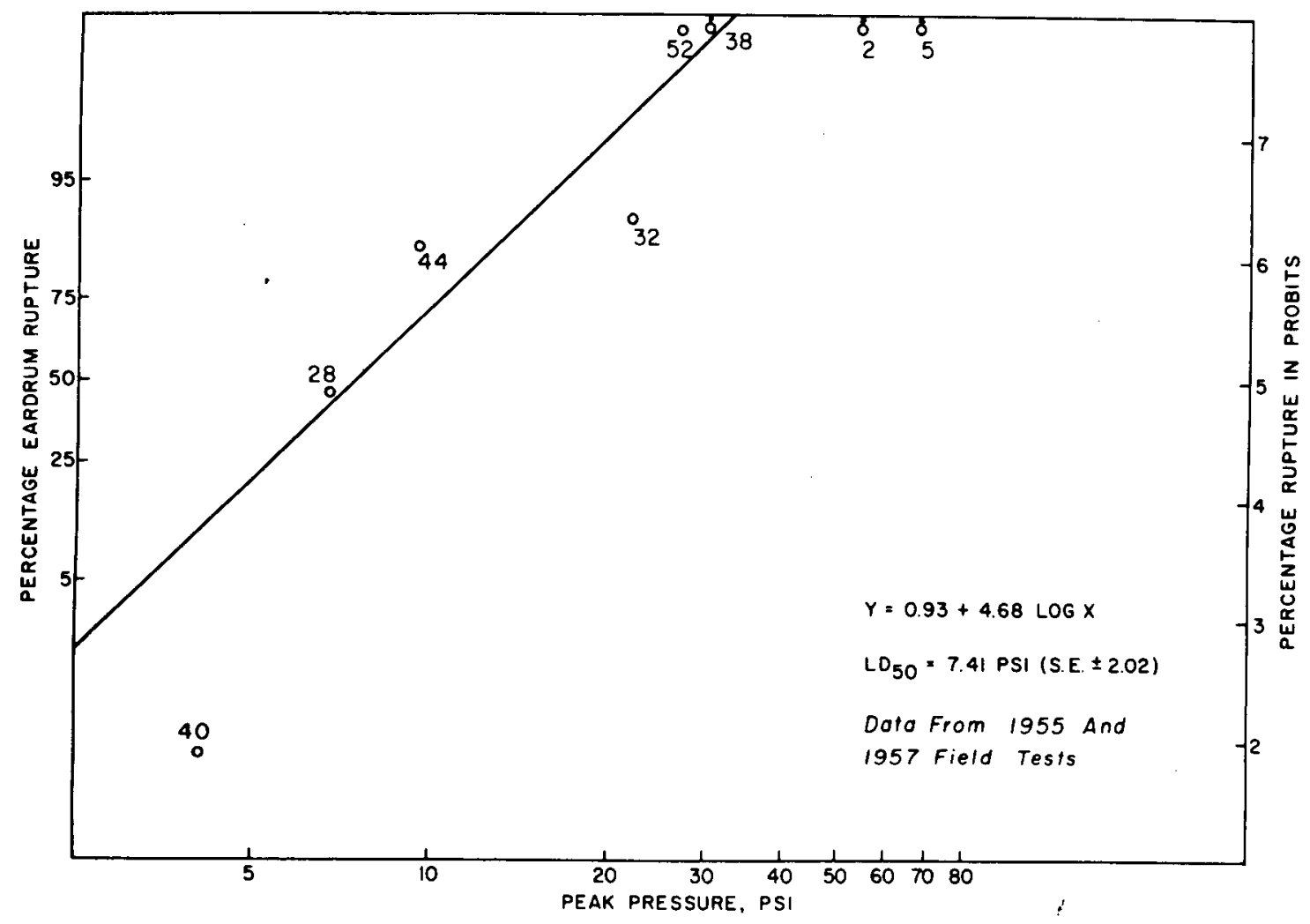

Fig. 3.15-Guinea pig eardrum rupture as related to peak pressure.

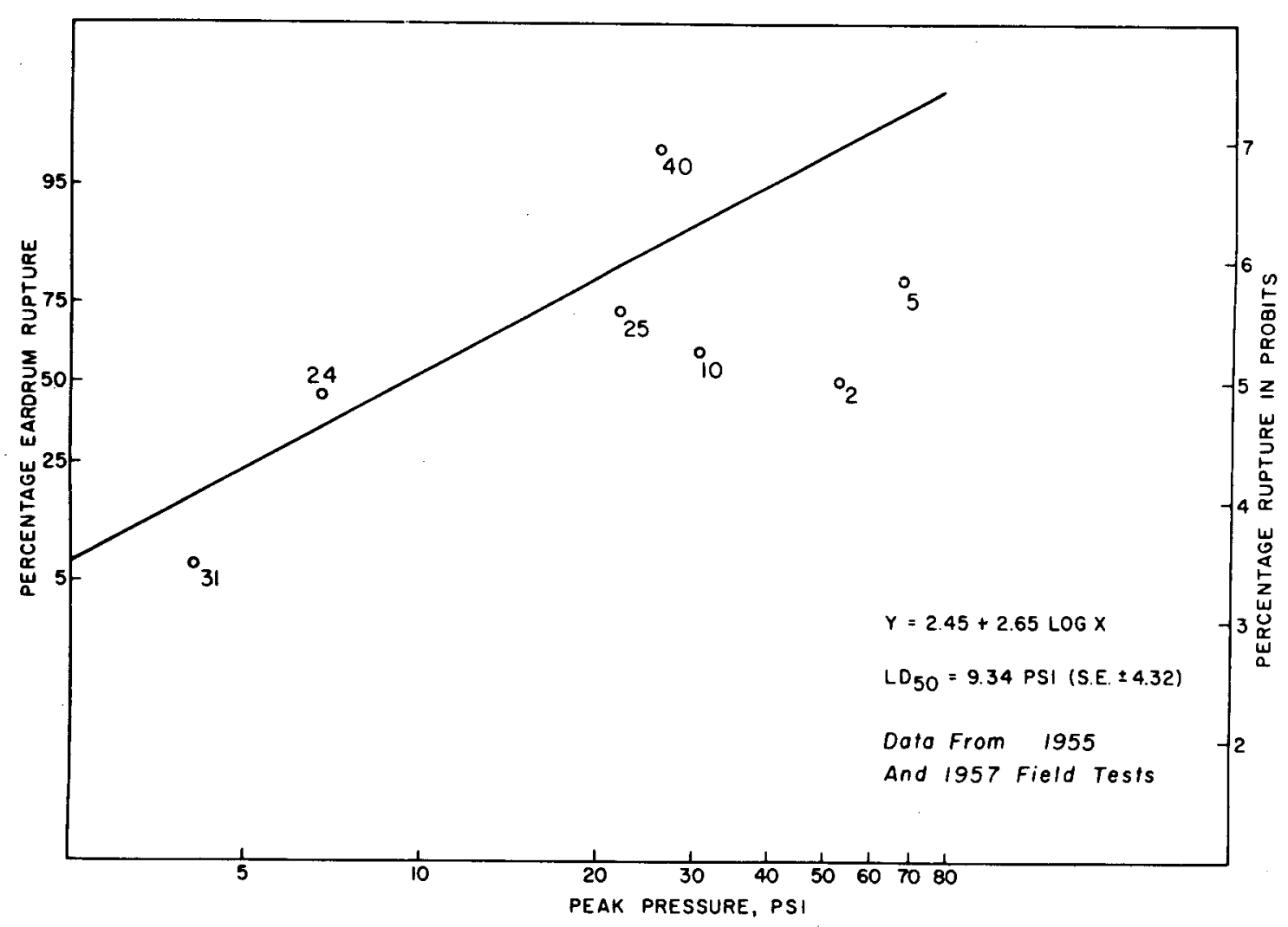

Fig. 3.16-Rabbit eardrum rupture as related to peak pressure. 


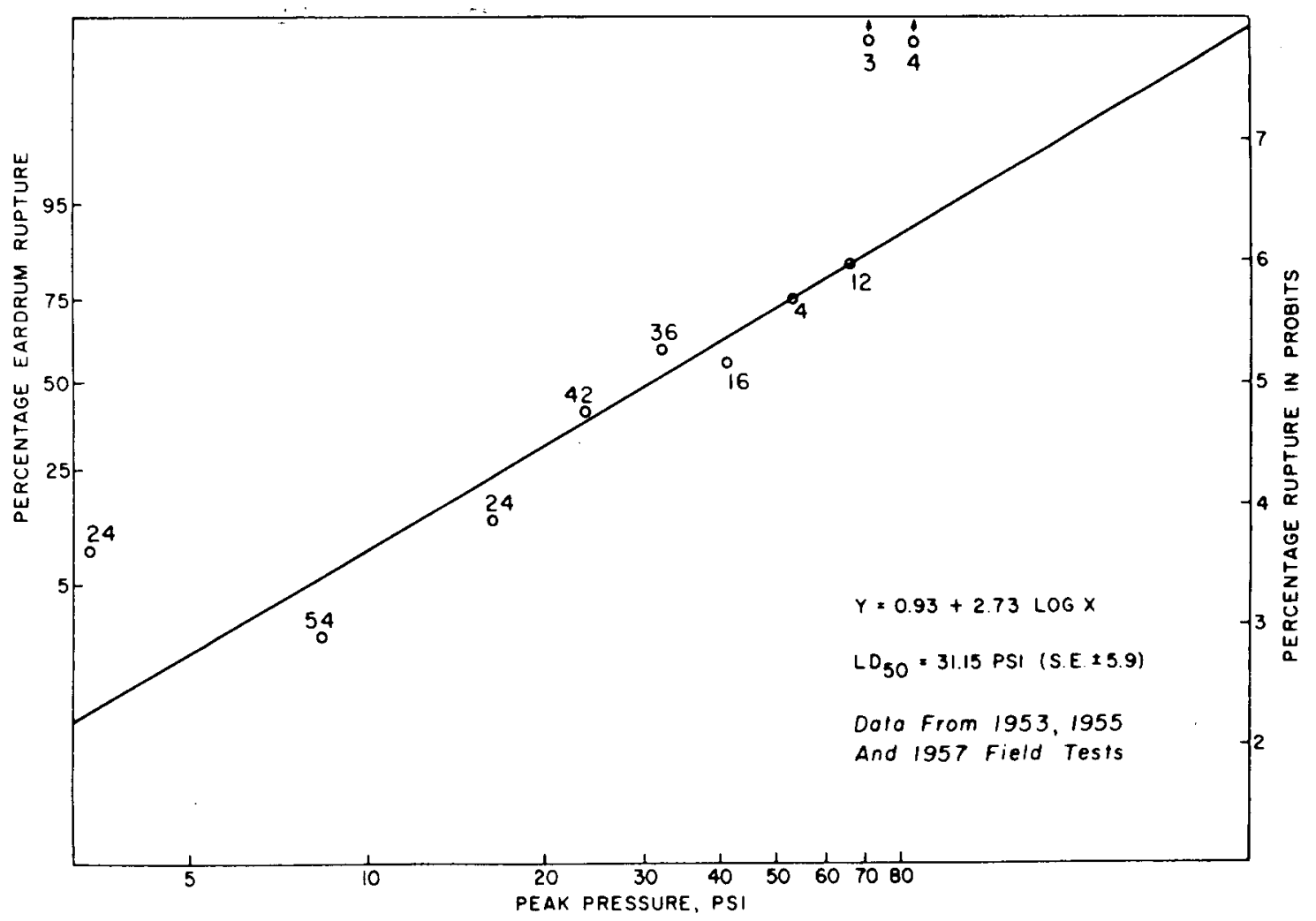

Fig. 3.17-Dog eardrum rupture as related to peak pressure.

In spite of the variables involved, it was possible to evaluate the aerodynamic mound in a semiquantitative manner by comparing the pressure-time histories within the slow-fill chambers for this operation with those noted in Operation Teapot when the mound was absent. A second method of evaluation was to compare the results with predicted values utilizing the prediction method of Clark. ${ }^{15}$ The latter will be described in Sec. 3.6.3.

\subsubsection{Comparison of the Incident With the Internal Pressure-Time With and Without the Aerodynamic Mound}

When the incident outside pressure-time data along with those recorded inside the slow-fill chamber are plotted, comparison of the different physical parameters can be approached. Such graphs are shown in Figs. 3.18 to 3.21 for 2 shots of Operation Plumbbob (P-1 and P-2) and 2 shots (T-1 and T -2) of Operation Teapot. From the figures it can be seen that the volume of the chambers differed only by the volume of the mound $(18 \mathrm{cu} \mathrm{ft})$. There was no mound on shots $\mathrm{T}-1$ and $\mathrm{T}-2$.

On shot T-1 (Fig. 3.20) the room filled through a 19.5-in.-diameter circular hole (area $2.07 \mathrm{sq} \mathrm{ft}$ ) in a steel plate bolted across the top of the escape hatch, $6 \mathrm{in}$. above and parallel with ground level. The same arrangement held true for T-2 (Fig. 3.21), except the diameter of the orifice was $36 \mathrm{in}$. (area $7.07 \mathrm{sq} \mathrm{ft}$ ). For comparative purposes the open area of the sieve plate (1.63 sq ft) was considered equivalent to a circular orifice $17.3 \mathrm{in}$. in diameter.

These facts along with other pertinent data are summarized in Table 3.10. Even though the incident blast waves varied in magnitude, duration, and in general wave form, several comparisons appear justified. First, Figs. 3.19 and 3.20, marked P-2 and T-1, respectively, offer possibility of comparison because the incident waves were roughly of the same magnitude and were of the nonideal type. Moreover, the effective area of the openings (1.63 and $2.07 \mathrm{sq} \mathrm{ft}$ ) differed only by about 22 per cent. According to Table 3.10 , the mound on shot P-2, with a total opening of $1.63 \mathrm{sq} \mathrm{ft}$, reduced the peak outside pressure 89.5 per cent, which was apparently no more effective than a larger total opening of $2.07 \mathrm{sq} f \mathrm{ft}$ without a mound on $\mathrm{T}-1$, where 


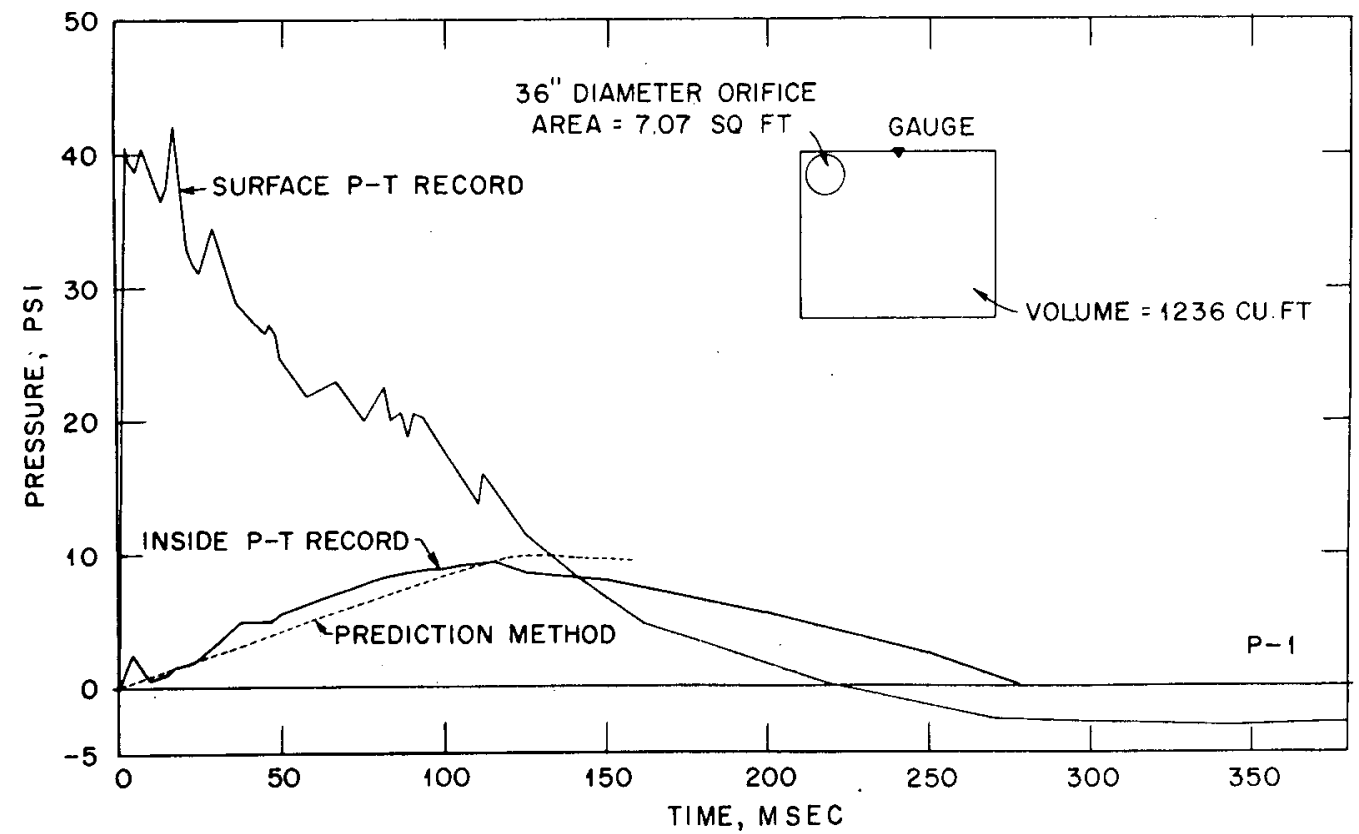

Fig. 3.18-Graph comparing the pressure-time recorded outside, within, and that predicted for inside the slow-fill chamber of shelter 8001 (Plumbbob).

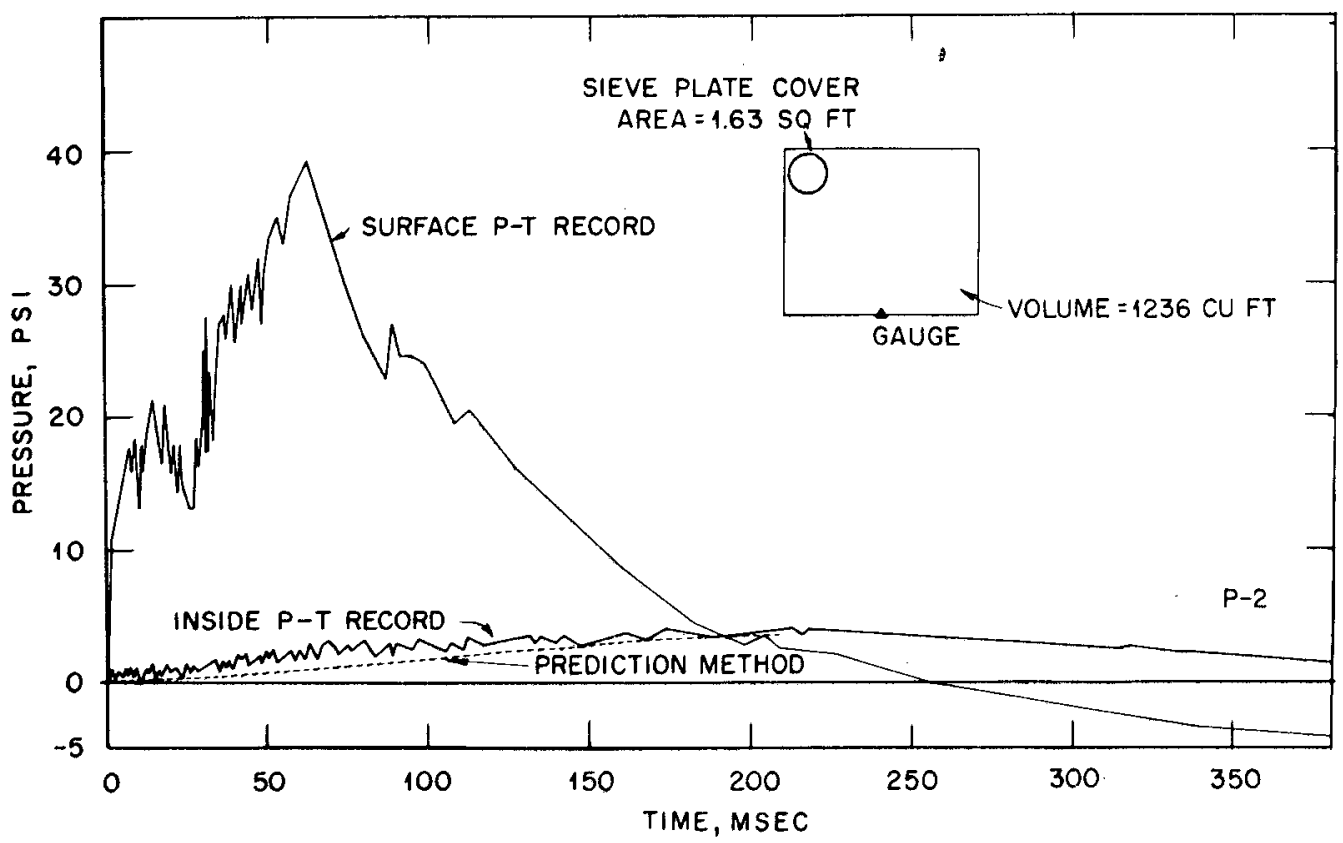

Fig. 3.19-Graph comparing the pressure-time recorded outside, within, and that predicted for inside the slow-fill chamber of shelter 8002 (Plumbbob). 


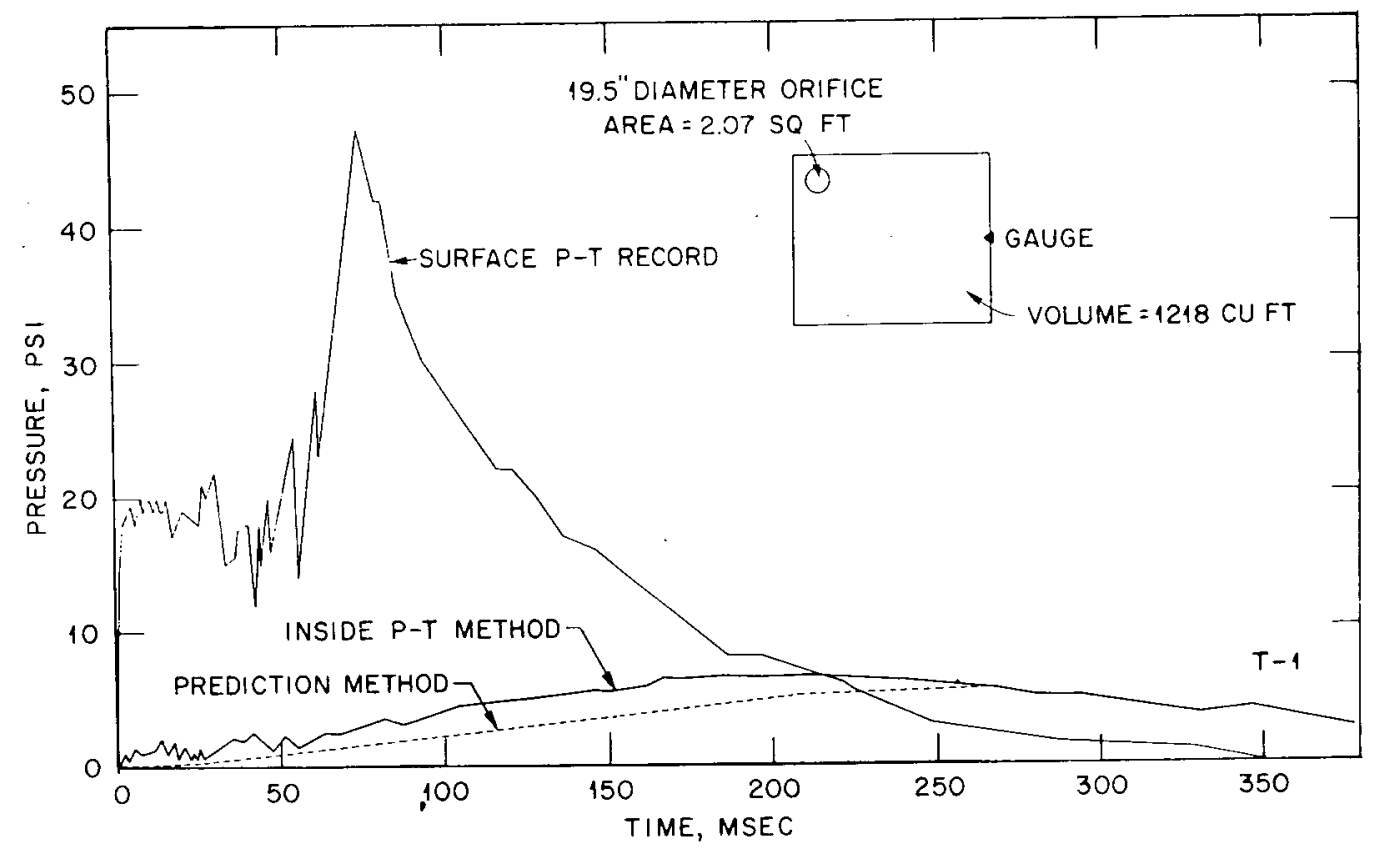

Fig. 3.20-Graph comparing the pressure-time recorded outside. within, and that predicted for inside the slow-fill chamber of shelter 8001 (Teapot).

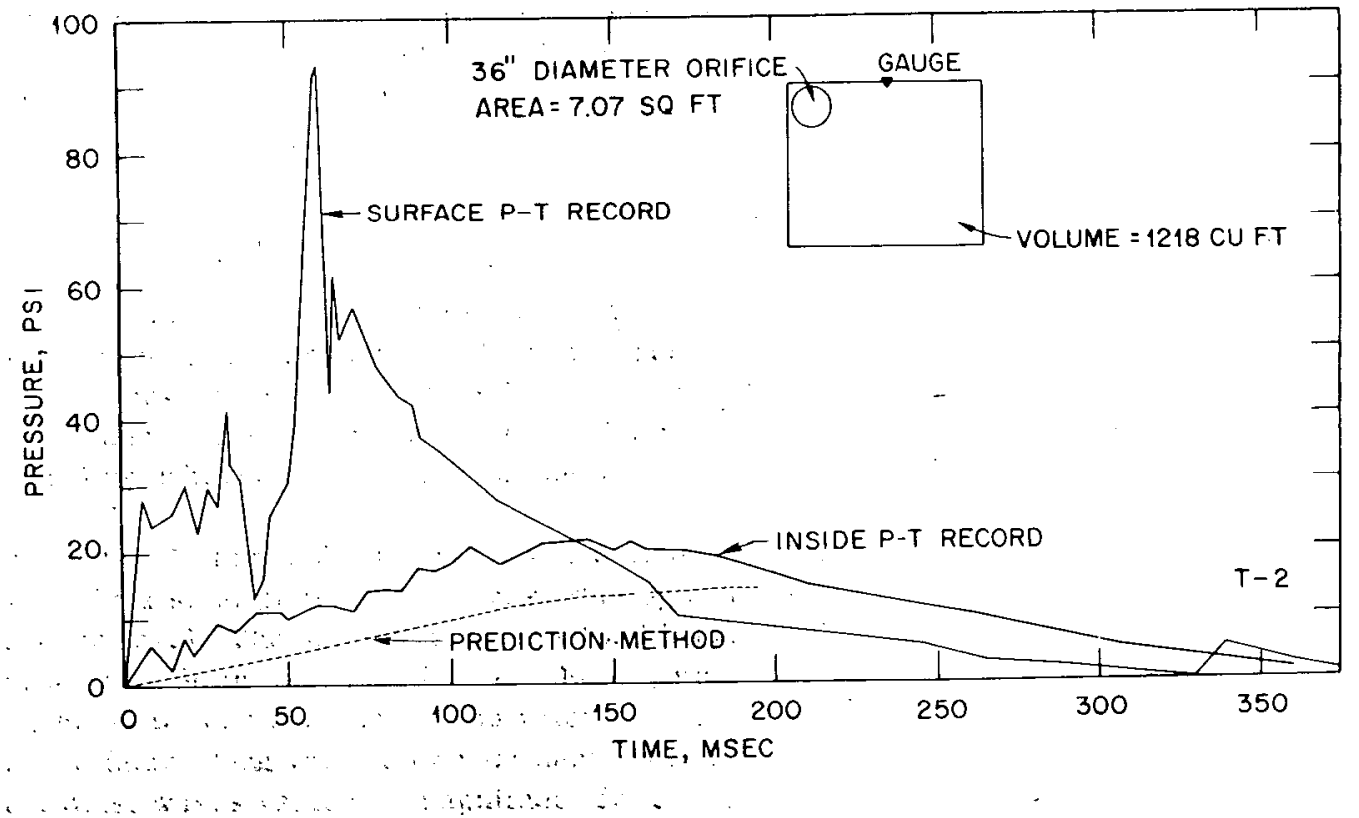

Fig. 3.21-Graph comparing the pressure-time recorded outside, within, and that predicted for inside the slow-fill chamber of shelter 8002 (Teapot). 
TABLE 3.10 - PRESSURE-TIME PARAMETERS WITHIN THE SLOW-FILL CHAMBER WITH AND WITHOUT THE AERODYNAMIC MOUND

\begin{tabular}{|c|c|c|c|c|c|c|c|}
\hline Designation of event & $\begin{array}{c}\text { Diameter } \\
\text { of orifice, } \\
\text { in. }\end{array}$ & $\begin{array}{l}\text { Area of } \\
\text { orifice, } \\
\text { sq ft }\end{array}$ & $\begin{array}{c}\text { Peak } \\
\text { pressure, } \\
\text { psi }\end{array}$ & $\begin{array}{c}\text { Reduction of } \\
\text { incident peak } \\
\text { pressure, } \%\end{array}$ & $\begin{array}{l}\text { Time to } \\
\text { peak } \\
\text { pressure, } \\
\text { msec }\end{array}$ & $\begin{array}{l}\text { Time } \\
\text { delay } \\
\text { in fill, } \\
\text { msec }\end{array}$ & $\begin{array}{c}\text { Duration of } \\
\text { positive } \\
\text { wave, msec }\end{array}$ \\
\hline \multicolumn{8}{|l|}{$\begin{array}{c}\text { P-2, 8002, mound } \\
\text { with sieve }\end{array}$} \\
\hline Outside & & & 39.2 & & 63 & & 255 \\
\hline Inside & $17.3 *$ & 1.63 & 4.1 & 89.5 & 174 & 91 & 506 \\
\hline \multicolumn{8}{|l|}{$\mathrm{T}-1$, no mound } \\
\hline Outside & & & 47.2 & & 76 & & 347 \\
\hline Inside & 19.5 & 2.07 & 6.7 & 85.8 & 210 & 134 & 637 \\
\hline \multicolumn{8}{|l|}{ P-1, 8001, mound } \\
\hline Outside & & & 42.1 & & 4 & & 220 \\
\hline Inside & 36.0 & 7.07 & 9.5 & 77.4 & 119 & 115 & 330 \\
\hline \multicolumn{8}{|l|}{$T-2$, no mound } \\
\hline Outside & & & 91.9 & & 60 & & 370 \\
\hline Inside & 36.0 & 7.07 & 21.5 & 76.6 & 139 & 79 & 568 \\
\hline
\end{tabular}

*The diameter of a circular inlet having the equivalent open area.

the peak pressure was reduced 85.8 per cent. Similarly the rise time and the duration of the overpressure in the room below the mound did not vary more than about 20 per cent in the two instances.

The other two events noted in Table $3.10(\mathrm{P}-1$ and $\mathrm{T}-2)$ were paired for comparison since their inlets had the same area. Here again it can be shown that the mound did not significantly reduce the peak pressure any more than did a simple opening approximately level with the ground (77.4 and 76.6 per cent, respectively). The duration of the positive phase was prolonged by a factor of about 1.5 in both instances. As for the time to peak pressure, it was delayed longer with the mound. Though this is understandable in view of the variation in the profile of the incident wave with its steep front that peaked rapidly in $4 \mathrm{msec}$ (Fig. 3.18 ), the two situations are not strictly comparable because of the variation in the form of the outside pressure pulse.

\subsubsection{Measured vs. Predicted Pressure-Time in Chamber}

The following formula, derived empirically by Clark ${ }^{15}$ at Ballistic Research Laboratories, was utilized to predict the rate of pressure increase in the slow-fill room.

$$
\frac{\Delta \mathbf{P}_{3}}{\Delta \mathrm{T}}=\frac{\mathrm{KA}}{\mathrm{V}}
$$

where $\frac{\Delta \mathrm{P}_{3}}{\Delta \mathrm{T}}=$ rate of chamber pressure rise, $\mathrm{pgl} / \mathrm{sec}$

$$
\begin{aligned}
A & =\text { area of } f \text { llling orifice, } s q \mathrm{ft} \\
V & =\text { volume of chamber, cu } \mathrm{ft} \\
K & =\mathfrak{f}\left(\mathrm{P}_{1}-\mathrm{P}_{3}\right) \\
\mathfrak{l} & =\text { an arbitrary function }
\end{aligned}
$$

Figure 3.22 is a graph of $K$ vs. $P_{1}-P_{3}$ taken from reference 15 .

To obtain the pressure-time curve for a chamber, one proceeds as follows: the expected $P-T$ curve is constructed, and, at $T=0, P_{1}-P_{3}$ is measured and $K$ is taken from the graph (Fig. 3.22). With this value of $K$, the volume, and the area, the rate of pressure rise is determined. The latter is drawn as a straight line with slope $\Delta \mathrm{P}_{3} / \Delta \mathrm{T}$, and the first portion of this: 


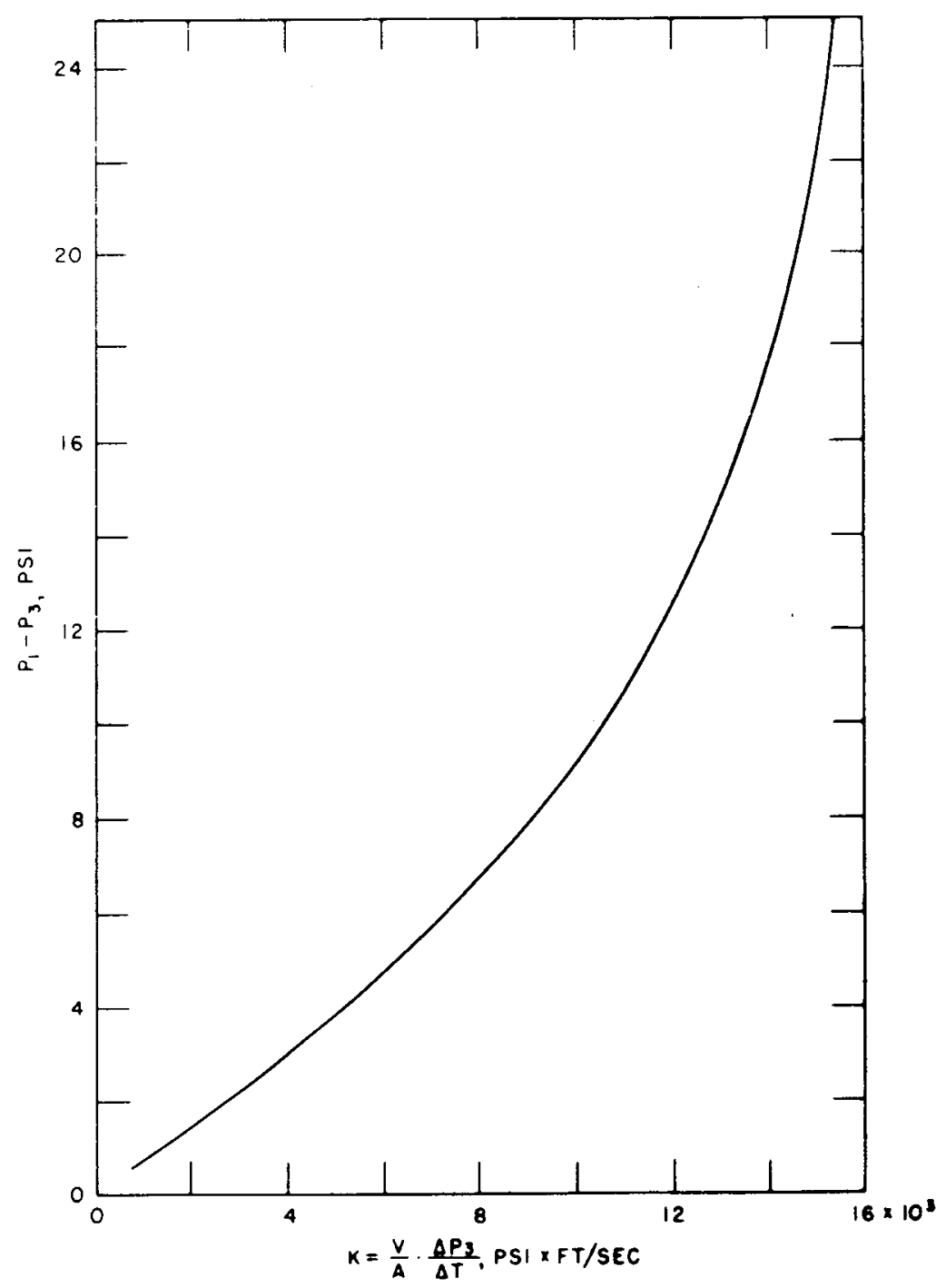

Fig. 3.22-A plot of values of $\mathrm{K}$ for pressure difference across an inlet.

line is taken as the first segment of the P-T curve. This procedure is repeated, each time assuming a point on the previous segment to measure the new $P_{1}-P_{3}$.

The calculated pressure vs. time curves for each of the four events were added to Figs. 3.18 through 3.21. The results are summarized in Table 3.11. As can be seen in Figs. 3.18 and 3.19 , the predicted and measured peak pressures and time to peak are in good agreement. Therefore the mound did not appear to alter the outside wave any more than would be predicted from a simple unaltered inlet having near the same open area.

\subsubsection{Comparison of the Wave Form in Chambers for Incident Waves of the Ideal and Nonideal Types}

The mound was tested completely open only on shot 1, and, since the incident blast wave was of the ideal type, the question arose, "How would the open mound perform had the incident wave been of the nonideal form?"

From the four events given in Table 3.10, it was possible to pick two situations for comparison in which the chamber volume, area, and nature of the inlets were identical, yet the outside wave forms were of the ideal and nonideal variety. In addition, the incident waves had about the same magnitude and duration. The wave incident to the fast-fill room of shelter 8001 


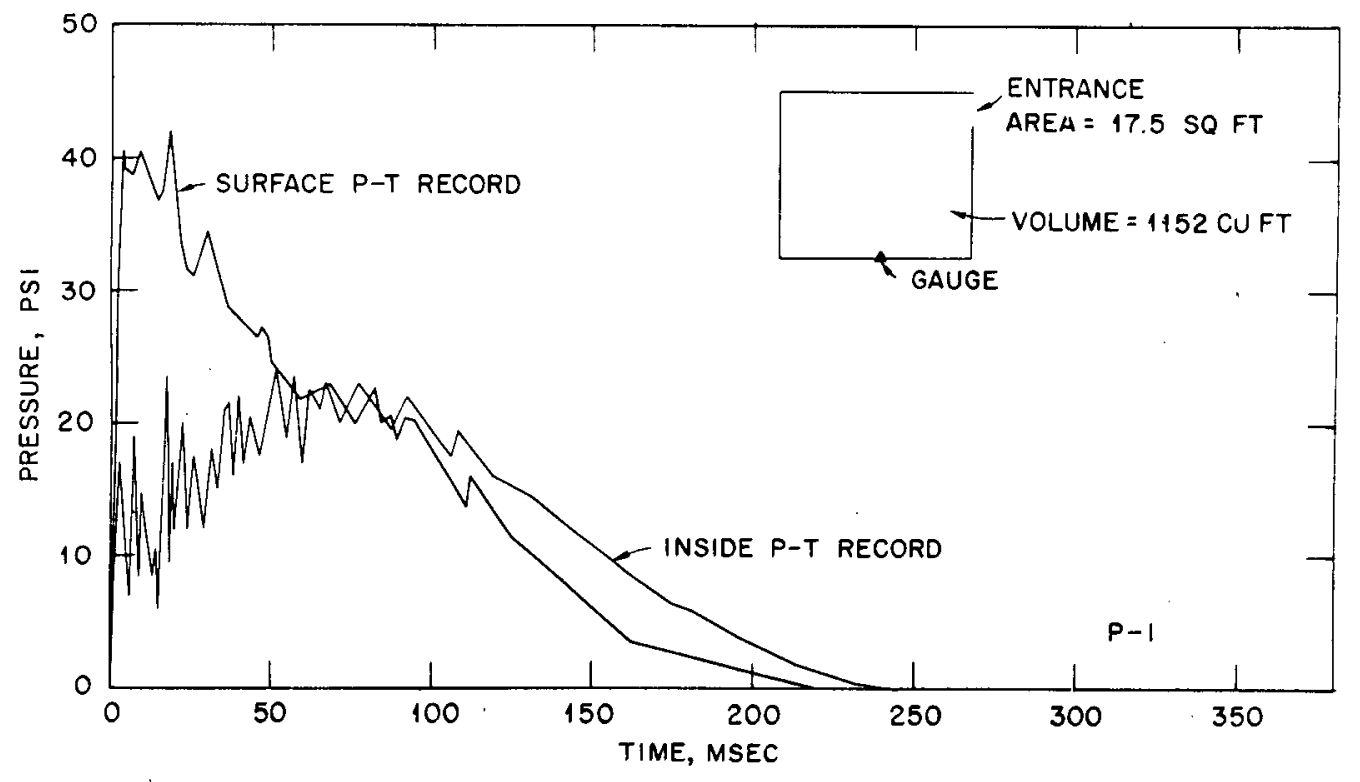

Fig. 3.23-Comparison of the pressure-time recorded outside and within the fast-fill chamber of shelter 8001 .

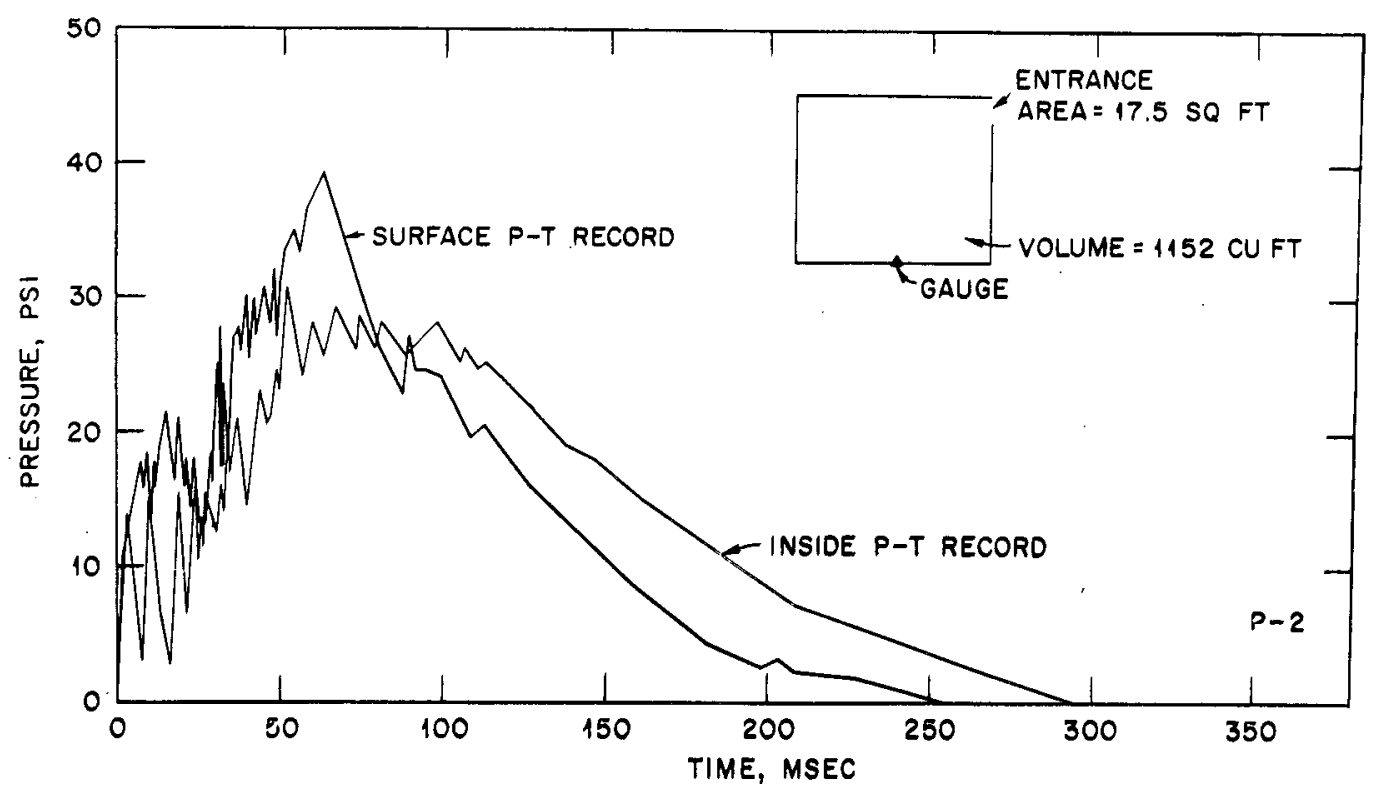

Fig. 3.24-Comparison of the pressure-tlme recorded outside and within the fast-flll chamber of shelter 8002 . 
TABLE 3.11 -COMPARISON OF THE MEASURED WITH THE PREDICTED PRESSURE-TIME: SLOW-FILL CHAMBERS

\begin{tabular}{lrrrr} 
& \multicolumn{2}{c}{ Peak pressure, psi } & \multicolumn{2}{c}{ Time to peak, msec } \\
Event & Measured & Predicted & Measured & Predicted \\
\hline P-1 (8001) & 9.5 & 9.8 & 120 & 130 \\
P-2 (8002) & 4.1 & 3.6 & 212 & 210 \\
T-1 & 6.7 & 5.5 & 215 & 230 \\
T-2 & 21.5 & 14.3 & 139 & 160 \\
\hline
\end{tabular}

TABLE 3.12- PRESSURE-TIME PARAMETERS INSIDE CHAMBERS* SUBJECTED TO IDEAL AND NONIDEAL INCIDENT BLAST WAVES

\begin{tabular}{ccccc}
\hline Gauge location & $\begin{array}{c}\text { Peak } \\
\text { pressure, } \\
\text { psi }\end{array}$ & $\begin{array}{c}\text { Percentage } \\
\text { of outside } \\
\text { peak } \\
\text { pressure }\end{array}$ & $\begin{array}{c}\text { Time to } \\
\text { peak } \\
\text { pressure, } \\
\text { msec }\end{array}$ & $\begin{array}{c}\text { Duration of } \\
\text { positive wave, } \\
\text { msec }\end{array}$ \\
\hline $\begin{array}{c}\text { 8001, ideal wave } \\
\text { Outside }\end{array}$ & 42.1 & & & \\
$\begin{array}{l}\text { Inside, fast-fill } \\
\text { 8002, nonideal wave }\end{array}$ & 23.8 & 56.5 & 50 & 220 \\
$\quad$ Outside & 39.2 & & & 245 \\
Inside, fast-fill & 30.5 & 77.8 & 63 & 255 \\
\hline
\end{tabular}

*Area of Inlet and volume of the fast-fill chamber was the same for both cases: $17.5 \mathrm{sq} f t$ and $1152 \mathrm{cu} \mathrm{ft}$.

was of the ideal type, and that filling the fast-fill room of shelter 8002 was nonideal. These inlets were both oriented the same - roughly "face-on" to Ground Zero; neither had a mound.

Plots of the incident and inside pressure-time curves for the two situations are shown in Figs. 3.23 and 3.24 for structures 8001 and 8002 , respectively. The significant parameters taken from these graphs are listed in Table 3.12. According to the table, the pressure rose to a higher proportion of the outside peak pressure in the case of the nonideal wave filling the chamber. That is, within the 8002 structure it attained 78 per cent of the outside values, and within the 8001 structure it reached only 57 per cent of that outside. The time to peak pressure was about $50 \mathrm{msec}$ in connection with the ideal wave and $68 \mathrm{msec}$ with the nonideal wave.

These comparisons suggest that had the blast wave outside structure 8001 on shot 1 been of the nonideal type, the pressure inside the slow-fill chamber probably would have risen even higher than 9.5 psi."

\section{REFERENCES}

1. H. M. Patt and A. M. Brues, The Pathological Physiology of Radiation Injury in the Mammal. II. Specific Aspects of the Physiology of Radiation Injury, in "Radiation Biology," edited by Alexander Hollaender, Vol. 1, Part 2, Chap. 15, pp. 959-1028, McGraw-Hill Book Company, Inc., New York, 1954.

2. C. S. White, T. L. Chiffelle, D. R. Richmond, W. H. Lockyear, I. G. Bowen, V. C. Goldizen, H. W. Merideth, D. E. Kilgore, B. B. Longwell, J. T. Parker, F. Sherping, and M. E. Cribb, The Biological Effects of Pressure Phenomena Occurring Inside Protective Shelters Following Nuclear Detonation, Operation Teapot Report, WT-1179, October 1956.

3. D. R. Richmond, M. B. Wetherbe, R. V. Taborelli, T. L. Chiffelle, and C. S. White, The Biological Response to Overpressure: I. Effects on Dogs of Five to Ten-Second Duration Overpressures Having Various Times of Pressure Rise, J. Aviation Med., 28: 447-460 (1957). 
4. D. R. Richmond, The Biological Response to Sharp-Rising Pressures of Long Duration, AEC Research Report, in preparation.

5. Robert O. Clark, personal communication, Jan. 28, 1959.

6. H. Borei, Report F.K.A., nr 265/8507 (Swedish) 1945, quoted by Clemedson, reference 7, p. 53.

7. Carl-Johan Clemedson, An Experimental Study on Air Blast Injuries, Acta Physiol. Scand., 18, Suppl. LXI, Uppsala (1949).

8. B. Cassen, K. Kistler, and W. Mankiewicz, Some Effects of Air Blast on Mechanically Constrained Mice, J. Aviation Med., 23: 120-129 (1952).

9. The work referred to was accomplished by a Lovelace Foundation team, consisting of J. E. Roberts, C. S. White, T. L. Chiffelle, W. H. Lockyear, J. P. Henry, M. A. Palmer, J. Clark, and W. A. Russell, working within the AEC Civil Effects Test Group, which is directed by Robert L. Corsbie.

10. D. J. Finney, "Probit Analysis. A Statistical Treatment of the Sigmoid Response Curve," 2d ed., Cambridge University Press, 1952.

11. Teofil Zalewski, Experimentelle Untersuchunger über die Resistenzfähigkeit des Trommelfells, Z. Ohrenheilk, 52: 109-128 (1906).

12. George M. Hass, Types of Internal Injuries of Personnel Involved in Aircraft Accidents, J. Aviation Med., 15: 77-84 (1944).

13. Donald Teare, Post-mortem Examination on Aircraft Victims, Brit. Med. J., 2: 707-708 (1951).

14. G. R. Osborn, Findings in 262 Fatal Accidents, Lancet, 2: 277 (1943).

15. Robert $O$. Clark, Pressure-Time History in a Chamber Subjected to Shock Wave Filling Through an Orifice, in "Proceedings of Second Shock Tube Symposium," Report SWR-TM58-3, pp. 101-117, Air Force Special Weapons Center, Mar. 5-6, 1958. 


\section{Chapter 4}

\section{DISCUSSION}

\subsection{BLAST EFFECTS}

\subsubsection{General}

One of the primary objectives of the present study was to obtain information that would aid in determining whether or not long-duration blast waves from nuclear detonations are biologically more hazardous than the short-duration blast waves of equivalent magnitude produced by high explosives. For this discussion the biological effects of blast have been divided into three parts. According to White ${ }^{1}$ they are

1. Primary effects: those associated with the application and/or the subsequent release of pressure, or a combination of these, upon an organism

2. Secondary effects: those resulting as a consequence of the biological target being struck with objects set in motion by or as a consequence of the blast

3. Tertiary effects: those injuries obtained as a result of the animal being translated by the blast wave

\subsubsection{Primary Blast}

Mortality. In general the pressure conditions to which animals were exposed in the present study were less severe than the conditions necessary for small-animal mortality, and the results add little to the understanding of the primary blast problem. Unfortunately this was also true of the experience during Operation Teapot; although animals were exposed to a wide range of peak pressures, the majority of them were exposed to peak pressures below 30 psi and few fatalities occurred. Consequently only tolerable conditions to the pressure wave forms encountered were documented, and neither the tolerance limits nor the significant physical parameters are known. Fatal conditions might well be only slightly higher; and, since blast mortality curves have been found to be very steep ${ }^{2,3}$ (a relatively small increase in pressure over threshold conditions covers the range from zero per cent mortality to 100 per cent), one must be careful not to underestimate the primary blast hazard.

\subsubsection{Secondary Blast}

Since precautionary steps were taken to prevent these effects within the shelters, such as firmly securing all objects that might become potential missiles, none were noted, and the reader is referred to specific studies concerning secondary effects by CETG Projects 33.4 (Operation Teapot, WT-1168) and 33.4 (Operation Plumbbob, WT-1470).

\subsubsection{Tertiary Blast}

The orientation of an animal, its velocity at impact, and the type of impact surface are undoubtedly of primary impcrtance in the pathology encountered in tertiary blast effects. Inside 
open shelters translation is an important problem, particularly just inside entryways. Aside from eardrum rupture, primary blast effects probably would not be found until conditions were above that where, for unrestrained animals, fatal conditions exist due to translation. This is no doubt particularly true for exposures in the open or inside heavy industrial buildings which might not be completely destroyed by blast.

\subsection{ENVIRONMENTAL EFFECTS OTHER THAN BLAST}

\subsubsection{Thermal Radiation}

It is not known at the present time the mechanism by which animals were burned inside a shelter out of the direct line of sight from the explosion. Among other things it has been suggested that the thermal effects in the shelter were a result of the heated air or hot dust carried in by the blast wave, reflection of the radiant energy, and aerodynamic heating due to compresion of the air. ${ }^{1}$ The authors are aware of the importance of thermal radiation, especially since thermal effects are so widespread in the environment surrounding a nuclear detonation.

\subsubsection{Ionizing Radiation}

The low levels of gamma and neutron radiations recorded inside the shelter on shot 1 were quite tolerable biologically and warrant no further comment. In contrast, the radiation levels inside shelter 8002 , although sufficient to kill all the guinea pigs saved from each chamber, were not high enough to kill the more radioresistant mice and rabbits. Unfortunately neutron measurements were not successfully obtained by CETG Project 39 within structure 8002 . The gamma dose of about $50 \mathrm{r}$ or less as recorded within 2 ft of their cages could not account for the mortality rate observed postshot. Judging from the mortality curves noted in the present study and information available in the literature regarding the order of sensitivity of the different mammals to radiation, ${ }^{4}$ the total dose of radiation accumulated by the animals within shelter 8002 must have amounted to between 300 to $350 \mathrm{r}$ (rep). Evidently neutron radiation contributed the major portion of the total dose.

\subsubsection{Dust}

As stated previously the dust concentrations within the shelters did not produce any recognizable effects on the animals.

\subsection{PROTECTIVE BAFFLES}

Unfortunately the solid baffle and the screen baffle were not tested under the same level of dynamic pressure. There was apparently considerable flow through the screen baffle, and, had the dynamic pressure been higher, the animal behind it would, in all probability, have received serious injury from translation. Since the solid baffle performed satisfactorily under rather high flow conditions, there seems little reason to consider the screen baffle or other untested types.

In open shelters or within closed structures where door fallure is a possibility, occupants behind baffles and, if possible, restrained, would experience minimized translational effects.

\subsection{AERODYNAMIC MOUND}

The two methods of comparing the effect of the aerodynamic mound on the fllling of the slow-fill chambers both agreed in that the outside wave was not attenuated by the presence of the mound. 


\section{REFERENCES}

1. C. S. White, T. L. Chiffelle, D. R. Richmond, W. H. Lockyear, I. G. Bowen, V. C. Goldizen, H. W. Merideth, D. E. Kilgore, B. B. Longwell, J. T. Parker, F. Sherping, and M. E. Cribb, The Biological Effects of Pressure Phenomena Occurring Inside Protective Shelters Following Nuclear Detonation, Operation Teapot Report, WT-1179, October 1956.

2. Hans Desaga, Blast Injuries, in "German Aviation Medicine, World War II," Vol. II, Chap. XIV-D, pp. 1274-1293, U. S. Government Printing Office, Washington, 1950.

3. D. R. Richmond, The Biological Response to Sharp-Rising Pressures of Long Duration, AEC Research Report, in preparation.

4. H. M. Patt and A. M. Brues, The Pathological Physiology of Radiation Injury in the Mammal. I. Physical and Biological Factors in Radiation Action, in "Radiation Biology," edited by Alexander Hollaender, Vol. 1, Part 2, Chap. 14, pp. 919-958, McGraw-Hill Book Company, Inc., New York, 1954. 


\section{Chapter 5}

\section{SUMMARY}

1. A total of 554 animals, including 24 dogs, 50 rabbits, 100 guinea pigs, and 380 mice were exposed in two open underground shelters each $1050 \mathrm{ft}$ from a separate nuclear detonation. Eight swine exposed within one of the shelters for thermal studies were also assessed for blast effects.

Each shelter was of similar design and partitioned into two rooms, each of $12 \times 12 \times 8 \mathrm{ft}$ dimensions. One room, filled through the main entrance, was termed the fast-fill chamber. The other, filled through an escape hatch of smaller area than the main entrance, was called the slow-fill chamber.

There were six BRL seif-recording pressure-time gauges inside and one outside each shelter. There was a gauge flush mounted into each of the walls of the fast-fill room and in two of the walls of the slow-fill room. A dynamic pressure-time gauge was stationed inside the door of each fast-fill chamber. In the shelter utilized on shot 1 , the sensing element of the gauge was $5 \mathrm{ft}$ from the door, and, in the other shelter on shot 2, it was $7 \mathrm{ft}$ inside the door.

Both shelters were instrumented inside and out with radiation dosimeters and radiation telemetering apparatus. The shelter involved on shot 2 also contained air-temperature measuring devices and dust-collecting trays.

2. On shot 1 the blast wave outside the shelter was 42.1 psi in magnitude with a positive duration of $220 \mathrm{msec}$. Within the fast-fill chamber an average peak pressure of $25.5 \mathrm{psi}$ (23.8 to 27.0) was recorded; the average duration was $269 \mathrm{msec}$. The peak dynamic pressure recorded in this chamber about $5 \mathrm{ft}$ inside the door was $10.5 \mathrm{psi}$.

Within the slow-fill room peak pressures of 9.0 and 10.0 psi were recorded. The pressure peaked in $119 \mathrm{msec}$, and the duration of the positive phase was $330 \mathrm{msec}$.

On shot 2, the incident blast wave was $39.2 \mathrm{psi}$ in magnitude and $255 \mathrm{msec}$ in duration. The average peak pressure in the fast-fill room was $30.3 \mathrm{psi}$ (30.0 to 30.5); on the average the pressure rose to a maximum in $65 \mathrm{msec}$ and endured for $300 \mathrm{msec}$. The peak dynamic pressure at $7 \mathrm{ft}$ inside the door was 2 psi.

Within the slow-fill chamber both gauges peaked at 4.1 psi; the average time to peak pressure was $203 \mathrm{msec}$, and the average duration was $512 \mathrm{msec}$.

3. The primary blast effects recorded at autopsy of animals exposed on shot 1 were as follows: for the fast-fill chamber in which the average peak pressure was $25.5 \mathrm{psi}$-mortality, $0 / 9$ dogs, $0 / 20$ rabbits, $2 / 35$ guinea pigs, and $3 / 120$ mice.

The pulmonary hemorrhages, tabulated from the autopsied animals, were found in $5 / 20$ rabbits, $7 / 35$ guinea pigs, and 19/60 mice. Three of 8 dogs sustained slight petechial lung hemorrhages.

In the slow-fill chamber where the average peak pressure was 9.5 psi, only eardrum effects were noted.

4. The primary effects of blast recorded at autopsy for the animals exposed on shot 2 were as follows: for the fast-fill chamber where the pressure peaked on the average at 30.3 psi - mortality, 15/80 mice, and $1 / 5$ swine. There were no canine, rabbit, or guinea pig 
fatalities. Pulmonary hemorrhages were found in $1 / 8$ dogs, $2 / 6$ rabbits, $8 / 12$ guinea pigs, 26/60 mice, and $3 / 5$ swine. All eardrums were examined and the results recorded, except for mice.

In the slow-fill chamber in which the peak pressure recorded was only 4.1 psi, no remarkable blast lesions other than eardrum rupture were recorded.

5. Two types of wind protective baffles were tested in each fast-fill room, one on either side of the door. On shot 1 the baffles were of solid steel plate; on shot 2 they were made of heavy wire screen. Dogs were exposed in pairs, one behind a baffle and one unprotected directly above or below the baffle.

The solid baffle protected a dog from a dynamic pressure of $10.5 \mathrm{psi}$ - the other animal at that location, unshielded, was seriously injured from translation. The screen baffle subjected to a dynamic pressure of 2 psi did not adequately shield the animal behind it; there was evidence that significant wind flow occurred through the screen.

6. No evidence of radiation injury was observed in the 110 mice and 2 dogs saved for 30 days following their exposure to about $5 \mathrm{r}$ of mixed gamma and neutron radiation on shot 1 .

Of the animals saved for radiation effects following shot 2 , the mortality observed was the following: $1 / 2$ swine, $1 / 14$ rabbits, and $16 / 16$ guinea pigs. (The results of the 60 mice saved for observation were obscured by a chronic infection of Salmonella in the colony.) Only gammaradiation measurements were successfully taken, and the animal mortality indicated that the total accumulated dose probably was higher than the recorded gamma dose by a factor of 6 or 7 .

7. Thermal effects were noted on animals exposed in the shelter on shot 2 . No thermal effects were observed after shot 1 . The thermal injuries occurred primarily among animals located in the entryway or just downstream of the door.

8. No symptoms of dust suffocation or accumulations of dust in the respiratory passageways were noted following the two shots even though there was a considerable amount of dust noted in the air inside the shelters at recovery about $3 \mathrm{hr}$ postshot.

9. An aerodynamic mound was tested in position above the escape hatch of each shelter. On shot 1 the mound's 36 -in. -diameter circular opening was left open. On shot 2 the inlet was covered with a sieve plate, a $1 / 2$-in.-thick steel plate having $1 / 4$-in.-diameter holes staggered on $1 / 2$-in. centers that afforded 23 per cent open area. In neither situation did the mound attenuate the blast wave any more than was found during past tests in which the same chambers filled through simple inlets of comparable diameter.

10. A probit analysis was applied to the eardrum data for 241 guinea pigs, 137 rabbits, and 219 dogs exposed during Operations Upshot-Knothole, Teapot, and Plumbbob. The $\mathrm{LD}_{50}$ values (the pressure required to rupture $\mathbf{5 0}$ of the eardrums) were calculated to be as follows: dogs, 31.2 psi; rabbits, 9.3 psi; and guinea pigs, 7.4 psi.

11. Results of the present study were compared with, and found to be in general agreement with, recent laboratory blast mortality findings. That is, unless the pressure wave has an initial shock or reflected shock of sufficient magnitude, primary blast damage (other than eardrum rupture and possibly sinus hemorrhage) is not likely to occur. And, in connection with reflected shock wayes, the geometry at exposure of the animal was found to be very important. 


\section{Appendix A}

\section{TABULATION OF PATHOLOGICAL FINDINGS FOR SHELTER 8001}

TABLE A.1-TABULATION OF PATHOLOGICAL FINDINGS FOR SHELTER 8001 : DOGS, RABBITS, AND GUINEA PIGS

\begin{tabular}{|c|c|c|c|c|c|c|}
\hline \multirow{2}{*}{$\begin{array}{l}\text { Animal } \\
\text { No. }\end{array}$} & \multirow{2}{*}{$\begin{array}{c}\text { Body } \\
\text { weight* }\end{array}$} & \multirow{2}{*}{$\begin{array}{l}\text { Lung } \\
\text { hemorrhage }\end{array}$} & \multirow{2}{*}{$\begin{array}{c}\text { Lung weight, } \\
\% \text { of } \\
\text { body weight }\end{array}$} & \multicolumn{2}{|c|}{$\begin{array}{l}\text { Eardrum } \\
\text { rupture }\end{array}$} & \multirow[b]{2}{*}{ Remarks } \\
\hline & & & & Right & Left & \\
\hline \multicolumn{7}{|c|}{ Dogs } \\
\hline \multicolumn{7}{|l|}{ Fast-fill } \\
\hline $\mathrm{K}-1$ & 15.4 & Slight $\dagger$ & 1.01 & $\mathbf{x}$ & $\mathbf{x}$ & $\begin{array}{l}\text { Translated and violently impacted; } \\
\text { sustained a fractured lumbar } \\
\text { vertebra and associated severed } \\
\text { spinal cord; ruptured spleen and } \\
\text { liver (massive hemoperito- } \\
\text { neum); dis rupted lining of uri- } \\
\text { nary bladder; laceration of the } \\
\text { anterior wall of I. V. septum } \\
\text { with hemopericardium }\end{array}$ \\
\hline $\mathrm{K}-2$ & 17.3 & None & & - & - & \\
\hline $\mathrm{K}-3$ & 17.7 & Slight $\ddagger$ & & NR & NR & $\begin{array}{l}\text { Two hemorrhagic areas in lung- } \\
\text { measured } 1 \frac{1}{2} \times 1 \frac{1}{2} \mathrm{~cm}\end{array}$ \\
\hline $\mathrm{K}-4$ & 20.4 & None & & - & $\mathbf{x}$ & \\
\hline $\mathrm{K}-5$ & 16.8 & Nonet & & $\mathbf{x}$ & $\mathbf{x}$ & Hemorrhagic right frontal sinus \\
\hline $\mathrm{K}-6$ & 14.1 & None & 1.11 & $\mathbf{x}$ & - & \\
\hline $\mathrm{K}-7$ & 15.4 & None & 0.82 & $\mathbf{x}$ & $\mathbf{x}$ & \\
\hline $\mathrm{K}-8$ & 17.7 & & & - & - & $\begin{array}{l}\text { Not sacrificed for immediate blast } \\
\text { effects }\end{array}$ \\
\hline \multirow[t]{3}{*}{$K-9$} & 16.8 & None & 1.11 & - & - & $\begin{array}{l}\text { A few petechia found microscopi- } \\
\text { cally in lung parenchyma }\end{array}$ \\
\hline & 16.8 & & 1.01 & & & \\
\hline & $\pm 0.6 \S$ & & $\pm 0.07 \S$ & & & \\
\hline \multicolumn{7}{|l|}{ Slow-fill } \\
\hline $\mathrm{K}-10$ & 16.8 & None & 1.15 & - & - & \\
\hline $\mathrm{K}-11$ & 13.2 & None & 1.04 & - & - & \\
\hline $\mathrm{K}-12$ & 14.1 & None & 1.06 & - & - & \\
\hline $\mathrm{K}-13$ & 15.9 & None & 1.13 & - & - & \\
\hline \multirow[t]{3}{*}{$K-14$} & 16.8 & & & - & - & $\begin{array}{l}\text { Not sacrificed for immediate blast } \\
\text { effects }\end{array}$ \\
\hline & 15.4 & & 1.10 & & & \\
\hline & $\pm 0.7 \S$ & & $0.03 \S$ & & & \\
\hline \multicolumn{7}{|c|}{ Rabbits } \\
\hline \multicolumn{7}{|l|}{ Fast-fill } \\
\hline R-1 & 2243 & Slight & 0.49 & $\mathrm{x}$ & $\mathbf{x}$ & \\
\hline $\mathrm{R}-2$ & 2238 & Slight & 0.45 & $x$ & $\mathbf{x}$ & \\
\hline $\mathrm{R}-3$ & 2420 & None & 0.45 & $\mathbf{x}$ & $x$ & \\
\hline $\mathrm{R}-4$ & 2758 & None & 0.47 & $x$ & $x$ & \\
\hline$R-5$ & 2450 & None & 0.45 & $\mathbf{x}$ & $\mathbf{x}$ & \\
\hline $\mathrm{R}-6$ & 2117 & None , & 0.47 & $\mathbf{x}$ & $x$ & \\
\hline $\mathrm{R}-7$ & 2473 & None & 0.48 & $\mathbf{x}$ & $x$ & \\
\hline R-8 & 1788 & None & 0.53 & $x$ & $x$ & \\
\hline $\mathrm{R}-9$ & 2439 & None & 0.47 & $\mathrm{x}$ & $x$ & \\
\hline$R-10$ & 1847 & None $\ddagger$ & 0.60 & $x$ & $\mathbf{x}$ & Slight emphysema \\
\hline
\end{tabular}


TABLE A.1-- (Continued)

\begin{tabular}{|c|c|c|c|c|c|c|}
\hline \multirow{2}{*}{$\begin{array}{l}\text { Animal } \\
\text { No. }\end{array}$} & \multirow{2}{*}{$\begin{array}{c}\text { Body } \\
\text { weight* }\end{array}$} & \multirow{2}{*}{$\begin{array}{l}\text { Lung } \\
\text { hemorrhage }\end{array}$} & \multirow{2}{*}{$\begin{array}{l}\text { Lung weight, } \\
\% \text { of } \\
\text { body weight }\end{array}$} & \multicolumn{2}{|c|}{$\begin{array}{l}\text { Eardrum } \\
\text { rupturet }\end{array}$} & \multirow[b]{2}{*}{ Remarks } \\
\hline & & & & Right & Left & \\
\hline \multicolumn{7}{|c|}{ Rabbits } \\
\hline \multicolumn{7}{|l|}{ Fast-flll } \\
\hline $\mathrm{R}-11$ & 2253 & None & 0.44 & $\mathbf{x}$ & $\mathrm{x}$ & \\
\hline$R-12$ & 2123 & None & 0.52 & $\mathbf{x}$ & $\mathbf{x}$ & \\
\hline $\mathrm{R}-13$ & 2151 & Slight & 0.46 & $\mathbf{x}$ & $\mathbf{x}$ & Emphysema \\
\hline $\mathrm{R}-14$ & 2524 & Slight & 0.52 & $\mathbf{x}$ & $\mathbf{x}$ & \\
\hline $\mathrm{R}-15$ & 2415 & Slight & 0.62 & $\mathbf{x}$ & $\mathbf{x}$ & \\
\hline $\mathrm{R}-16$ & 2300 & None & 0.43 & $\mathrm{x}$ & $\mathbf{x}$ & \\
\hline$R-17$ & 3870 & None & 0.28 & $\mathbf{x}$ & $\mathbf{x}$ & \\
\hline$R-18$ & .2321 & None & 0.43 & $\mathbf{x}$ & $\mathbf{x}$ & \\
\hline $\mathrm{R}-19$ & 2149 & None & 0.70 & $\mathbf{x}$ & $\mathbf{x}$ & \\
\hline \multirow[t]{3}{*}{$\mathrm{R}-20$} & 2192 & None & 0.46 & $\mathbf{x}$ & - & \\
\hline & 2354 & & 0.49 & & & \\
\hline & $\pm 94.1 \S$ & & $\pm 0.02 \S$ & & & \\
\hline \multicolumn{7}{|c|}{ Guinea Pigs } \\
\hline \multicolumn{7}{|l|}{ Fast-flll } \\
\hline GP-1-1 & 380 & None & 0.89 & $\mathbf{x}$ & $\mathbf{x}$ & Pneumonitis \\
\hline 2 & 416 & None $\ddagger$ & 1.47 & $\mathbf{x}$ & $\mathrm{x}$ & Pneumonitis $\$$ \\
\hline 3 & 527 & None & 0.70 & $\mathbf{x}$ & $\mathbf{x}$ & $\begin{array}{l}\text { Petechial hemorrhage and } \\
\text { emphysema }\end{array}$ \\
\hline 4 & 385 & None $\ddagger$ & 1.01 & NR & NR & Pneumonitis $\ddagger$ \\
\hline 5 & 437 & None & 1.97 & $\mathbf{x}$ & $\mathbf{x}$ & Pneumonitis \\
\hline GP-2-1 & 487 & None & 0.86 & $\mathbf{x}$ & $\mathbf{x}$ & Pneumonitis \\
\hline 2 & 455 & Slight & 1.60 & $\mathrm{x}$ & $\mathbf{x}$ & \\
\hline 3 & 505 & slight $\ddagger$ & 1.46 & NR & NR & Pneumonitis and bronchitis \\
\hline 4 & 472 & None & 0.70 & $\mathbf{x}$ & $\mathbf{x}$ & Pneumonitis \\
\hline 5 & 471 & None & 0.83 & $\mathbf{x}$ & $\mathbf{x}$ & Pneumonitis \\
\hline GP-2a-1 & 441 & None & 0.86 & $\mathbf{x}$ & $\mathbf{x}$ & \\
\hline 2 & 448 & None & 0.85 & $\mathbf{x}$ & $\mathbf{x}$ & \\
\hline 3 & 396 & None & 0.93 & $\mathbf{x}$ & $\mathbf{x}$ & \\
\hline 4 & 545 & None & 0.82 & $\mathbf{x}$ & $\mathbf{x}$ & \\
\hline 5 & 461 & Moderate & 1.21 & $\mathbf{x}$ & $\mathbf{x}$ & \\
\hline GP-3-1 & 396 & Moderate $\neq$ & 2.68 & $\mathbf{x}$ & $x$ & $\begin{array}{l}\text { Dead on recovery; ruptured } \\
\text { stomach and bronchitis }\end{array}$ \\
\hline 2 & 470 & None & 0.91 & $x$ & $\mathbf{x}$ & \\
\hline 3 & 448 & Slight & 1.63 & $\mathbf{x}$ & $\mathbf{x}$ & Pneumonitis \\
\hline 4 & 413 & Slight & 0.97 & NR & NR & \\
\hline 5 & 420 & None & 0.98 & NR & NR & \\
\hline GP-4-1 & 319 & None & 1.00 & $\mathbf{x}$ & $\mathbf{x}$ & Pneumonitis \\
\hline 2 & 606 & None & 0.89 & NR & NR & Pneumonitis \\
\hline 3 & 494 & None & 1.07 & NR & NR & Pneumonitis \\
\hline 4 & 510 & None & 1.08 & $\mathbf{x}$ & $\mathbf{x}$ & Pneumonitis \\
\hline 5 & 586 & None & 0.63 & $x$ & $\mathbf{x}$ & \\
\hline GP-5-1 & 403 & None & 0.64 & $\mathrm{x}$ & $x$ & \\
\hline 2 & 423 & Nonet & 0.80 & $\mathbf{x}$ & $\mathbf{x}$ & \\
\hline 3 & 386 & Nonet & 0.88 & $\mathrm{x}$ & $\mathrm{x}$ & \\
\hline 4 & 338 & Nonet & 1.15 & $\mathbf{x}$ & $\mathrm{x}$ & Pneumonitis \\
\hline 5 & 328 & Nonet & 1.92 & $\mathbf{x}$ & $\mathbf{x}$ & \\
\hline
\end{tabular}


TABLE A.1 - (Continued)

\begin{tabular}{|c|c|c|c|c|c|c|}
\hline \multirow{2}{*}{$\begin{array}{l}\text { Animal } \\
\text { No. }\end{array}$} & \multirow{2}{*}{$\begin{array}{c}\text { Body } \\
\text { weight* }\end{array}$} & \multirow{2}{*}{$\begin{array}{c}\text { Lung } \\
\text { hemorrhage }\end{array}$} & \multirow{2}{*}{$\begin{array}{l}\text { Lung weight, } \\
\% \text { of } \\
\text { body weight }\end{array}$} & \multicolumn{2}{|c|}{$\begin{array}{l}\text { Eardrum } \\
\text { rupturet }\end{array}$} & \multirow[b]{2}{*}{ Remarks } \\
\hline & & & & RIght & Left & \\
\hline & & & uinea Pigs & & & . \\
\hline \multicolumn{7}{|l|}{ Fast-fill } \\
\hline GP-6-1 & 623 & None & 0.83 & $\mathbf{x}$ & $\mathbf{x}$ & \\
\hline 2 & 586 & None & 1.02 & NR & NR & Pneumonltis \\
\hline 3 & 314 & None & 1.59 & $\mathbf{x}$ & $\mathbf{x}$ & Dead on recovery \\
\hline 4 & 513 & None & 0.88 & NR & NR & \\
\hline \multirow[t]{3}{*}{5} & 452 & None & 1.15 & NR & NR & \\
\hline & 453 & & 1.11 & & & \\
\hline & $\pm 13 \S$ & & \pm 0.078 & & & \\
\hline \multicolumn{7}{|l|}{ Slow-fill } \\
\hline GP-7-1 & 382 & None & 1.12 & $\mathbf{x}$ & $\mathbf{x}$ & Pneumonltis \\
\hline 2 & 439 & None & 0.86 & $x$ & $\mathbf{x}$ & Pneumonitis \\
\hline 3 & 508 & None & 1.10 & - & - & \\
\hline 4 & 500 & Nonet & 0.90 & $\mathbf{x}$ & $\mathbf{x}$ & \\
\hline 5 & 590 & None & 0.85 & - & $\mathbf{x}$ & \\
\hline GP-8-1 & 434 & None & 0.83 & $\mathbf{x}$ & $\mathbf{x}$ & \\
\hline 2 & 418 & None & 1.44 & $\mathbf{x}$ & $\mathbf{x}$ & \\
\hline 3 & 497 & Nonet & 0.86 & - & - & Bronchitis \\
\hline 4 & 608 & Nonet & 0.76 & $\mathbf{x}$ & $\mathbf{x}$ & \\
\hline 5 & 541 & None & 0.92 & $\mathbf{x}$ & $\mathbf{x}$ & \\
\hline GP-9-1 & 509 & None & 1.16 & $\mathbf{x}$ & $\mathbf{x}$ & Pneumonitis \\
\hline 2 & 382 & None & 1.10 & $\mathbf{x}$ & $\mathbf{x}$ & \\
\hline 3 & 497 & None & 0.66 & NR & $x$ & \\
\hline 4 & 464 & None & 1.79 & $\mathbf{x}$ & $\mathbf{x}$ & Pneumonitis \\
\hline 5 & 437 & None & 1.17 & $\mathbf{x}$ & $\mathbf{x}$ & \\
\hline GP-10-1 & 557 & None $\ddagger$ & 0.65 & NR & NR & \\
\hline 2 & 547 & None & 0.73 & $\mathbf{x}$ & $\mathbf{x}$ & \\
\hline 3 & 466 & None & 0.79 & $\mathbf{x}$ & $\mathbf{x}$ & \\
\hline 4 & 624 & None & 0.90 & NR & NR & \\
\hline 5 & 403 & Nonet & 1.24 & $\mathbf{x}$ & $x$ & \\
\hline GP-11-1 & 370 & None & 2.24 & - & $\mathbf{x}$ & \\
\hline 2 & 398 & None & 1.00 & $\mathbf{x}$ & $\mathbf{x}$ & \\
\hline 3 & 340 & None & 1.47 & $\mathbf{x}$ & $\mathbf{x}$ & Pneumonitis \\
\hline 4 & 354 & (Questionable) & 1.47 & $x$ & $\mathbf{x}$ & Pneumonitis \\
\hline \multirow[t]{3}{*}{5} & 461 & None & 1.50 & $\mathbf{x}$ & NR & \\
\hline & 469 & & 1.10 & & & \\
\hline & \pm 168 & & \pm 0.088 & & & \\
\hline
\end{tabular}

*Body weights are in kilograms for dogs and in grams for rabbits and guinea plgs.

$\nmid x,-$, and NR indicate that the eardrums were ruptured, intact, or not readable, respectively. $\ddagger$ Findings verified histologically.

\$Mean and standard error of the mean. 
TABLE A.2-TABULATION OF PATHOLOGICAL FINDINGS FOR SHELTER 8001: MICE

\begin{tabular}{ccc}
\hline Cage No. & Mortality & Lung hemorrhage \\
\hline Fast-fill & & \\
$1^{*}$ & $1 / 10$ & $0 / 10$ \\
2 & $2 / 10$ & $10 / 10$ \\
3 & $0 / 10$ & $0 / 10$ \\
4 & $0 / 10$ & $2 / 10$ \\
5 & $0 / 10$ & $4 / 10$ \\
6 & $0 / 10$ & $0 / 10$ \\
Slow-fill & & \\
7 & $0 / 10$ & $0 / 10$ \\
8 & $0 / 10$ & $0 / 10$ \\
9 & $0 / 10$ & $0 / 10$ \\
10 & $0 / 10$ & $0 / 10$ \\
11 & $0 / 10$ & $0 / 10$ \\
\hline
\end{tabular}

*Saved 10 mice from each cage of 20 for the observation of radiation effects.

No thermal effects were noted in any of the mice from shelter 8001 . 


\section{Appendix B}

\section{TABULATION OF PATHOLOGICAL FINDINGS FOR SHELTER 8002}

TABLE B.1 - TABULATION OF PATHOLOGICAL FINDINGS FOR SHELTER 8002: DOGS, SWINE, RABBITS, AND GUINEA PIGS

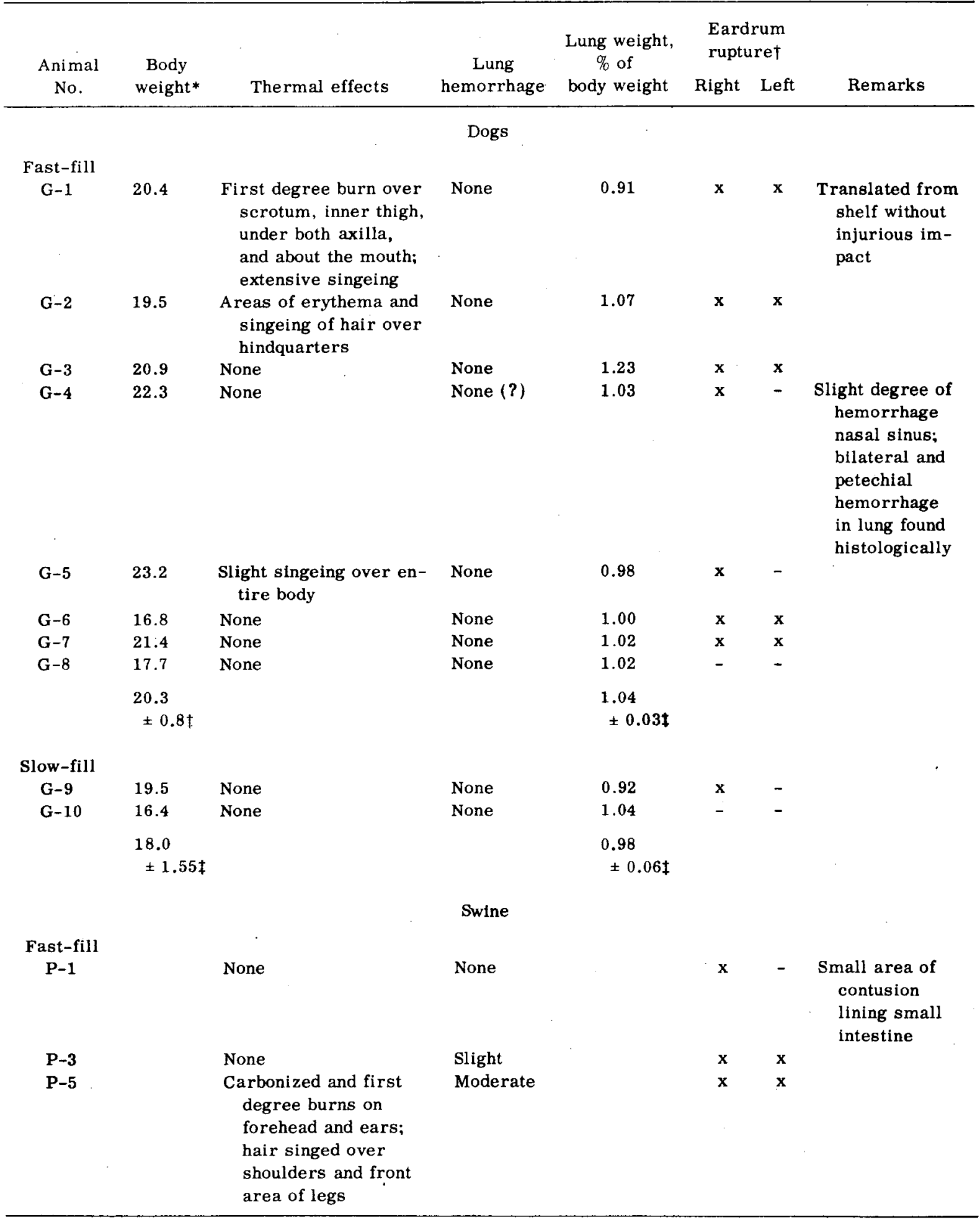


TABLE B.1-(Continued)

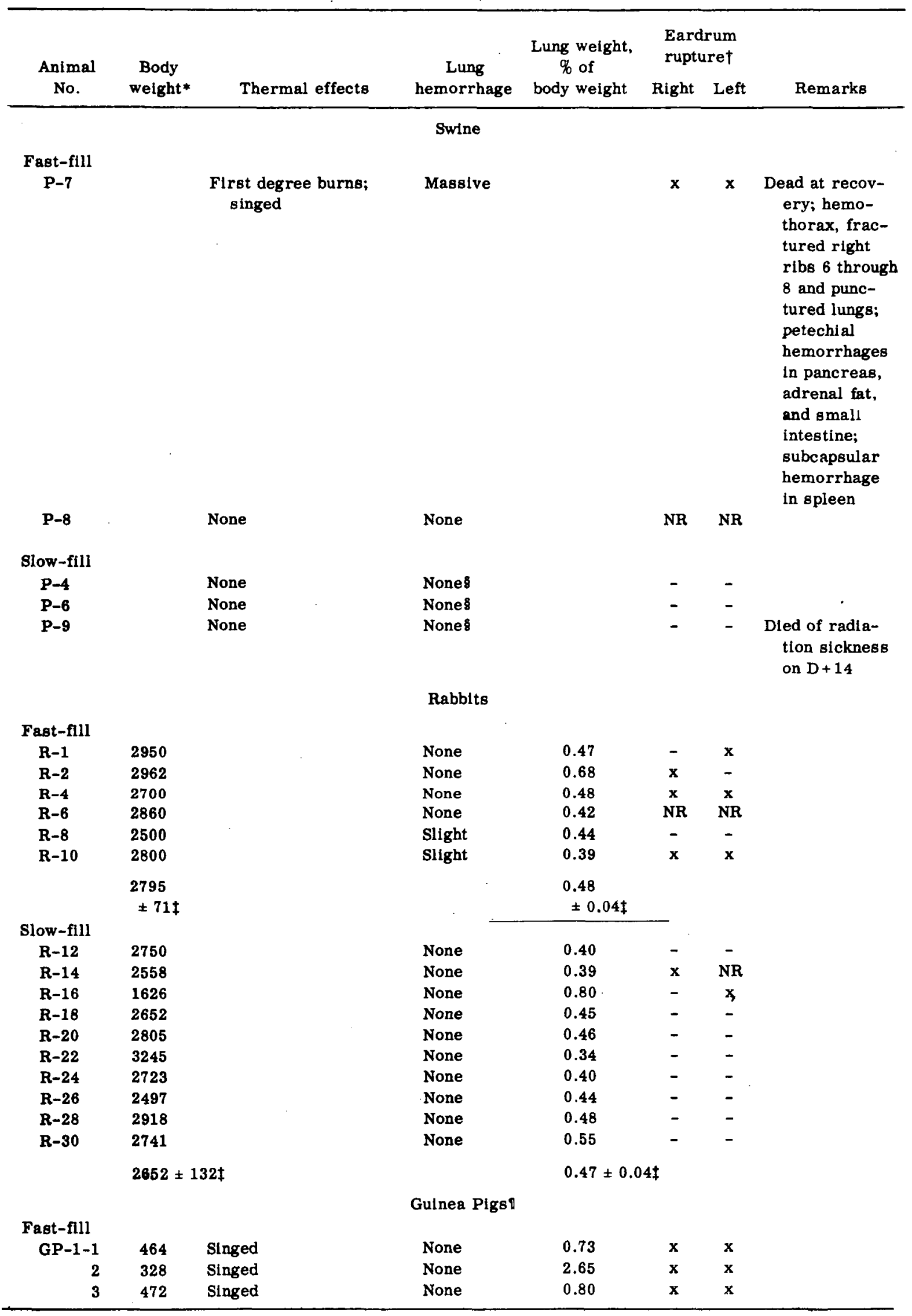


TABLE B.1-(Continued)

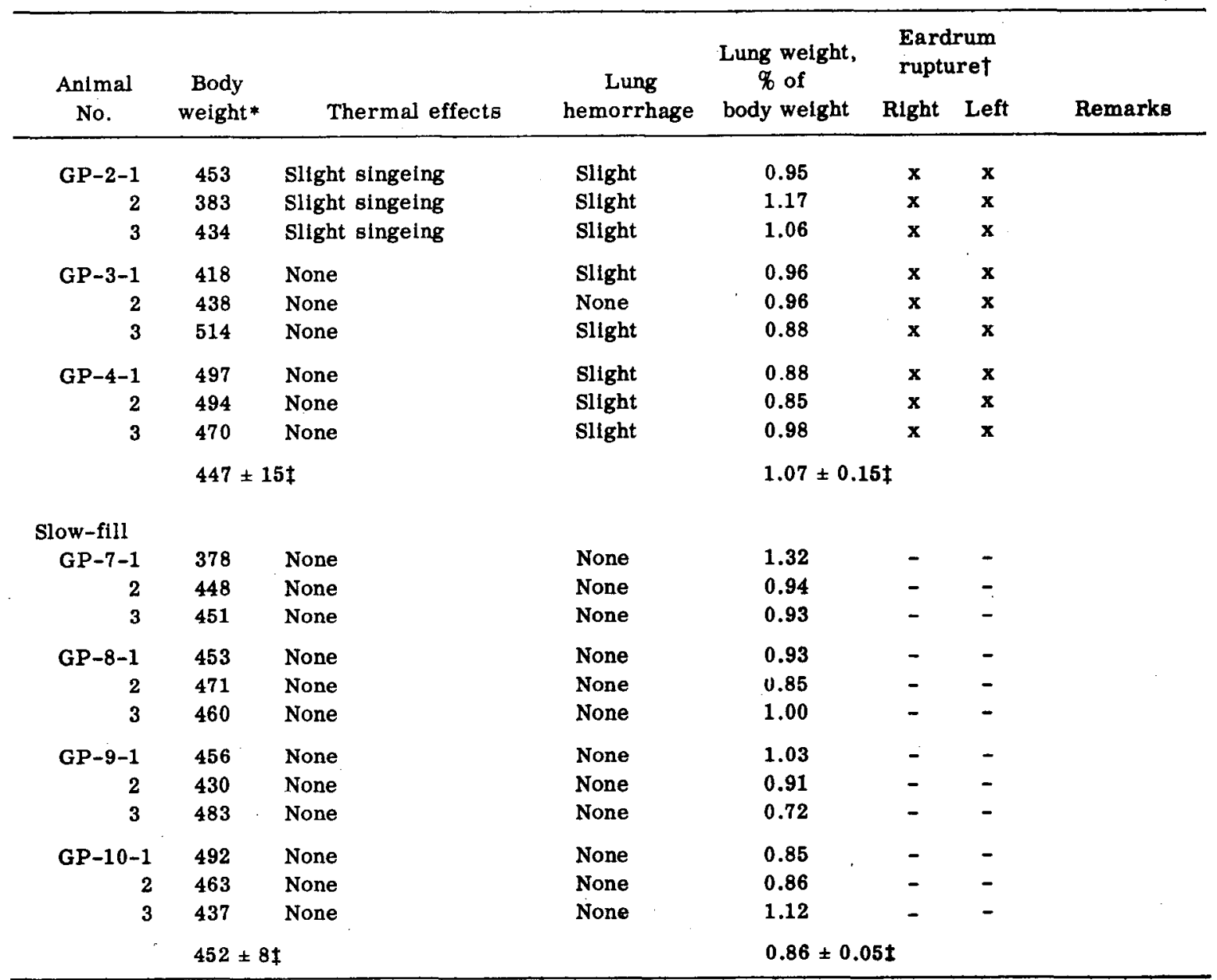

*Body weights are in kilograms for dogs and in grams for gulnea pigs and rabbits.

$\dagger \mathrm{x},-$, and NR indicate that the eardrums were ruptured, intact, or not readable, respectively.

tMean and standard error of the mean.

\$Saved for observation of radiation effects.

TThere were 2 animals saved from each cage (Nos. 4 and 5) for observation of radiation effects.

TABLE B:2 - TABULATION OF PATHOLOGICAL FINDINGS FOR SHELTER 8002: MICE

\begin{tabular}{cccc}
\hline Cage No.* & Mortality & Thermal effects & $\begin{array}{c}\text { Lung } \\
\text { hemorrhage }\end{array}$ \\
\hline $\begin{array}{c}\text { Fast-fill } \\
1\end{array}$ & $14 / 20$ & $\begin{array}{c}20 / 20 \text { burned and } \\
\text { singed }\end{array}$ & $18 / 20$ \\
2 & $1 / 20$ & $\begin{array}{c}9 / 20 \text { singed; } 2 / 20 \\
\text { burned }\end{array}$ & $7 / 20$ \\
4 & $0 / 20$ & $0 / 20$ & $1 / 20$ \\
Slow-fll & & $0 / 20$ & $0 / 20$ \\
8 & $0 / 20$ & $0 / 20$ & $0 / 20$ \\
\hline 10 & $0 / 20$ & $0 / 20$ &
\end{tabular}

*Saved all 20 mice from cages 3,7 , and 9 for radiation effects. 